NBER WORKING PAPER SERIES

\title{
THE CORPORATE GOVERNANCE ROLE OF THE MEDIA: EVIDENCE FROM RUSSIA
}

\author{
Alexander Dyck \\ Natalya Volchkova \\ Luigi Zingales \\ Working Paper 12525 \\ http://www.nber.org/papers/w12525
NATIONAL BUREAU OF ECONOMIC RESEARCH
1050 Massachusetts Avenue
Cambridge, MA 02138
September 2006

\begin{abstract}
Alexander Dyck thanks the Gamma Foundation, the Division of Research, Harvard Business School, and the Rotman School of Management for financial support. Luigi Zingales thanks the Gamma Foundation, the CRSP center, and the George Stigler Center at the University of Chicago for financial support. We thank Beatriz Armendariz, Stefano della Vigna. Andrei Shleifer, Andrei Simonov and participants and seminars at Dartmouth, Harvard, Stockholm School of Economics and the NBER for very useful comments. We thank Mehmet Beceren and Victor Xin for their research assistance. The views expressed herein are those of the author(s) and do not necessarily reflect the views of the National Bureau of Economic Research.

(C2006 by Alexander Dyck, Natalya Volchkova and Luigi Zingales. All rights reserved. Short sections of text, not to exceed two paragraphs, may be quoted without explicit permission provided that full credit, including (C) notice, is given to the source.
\end{abstract}


The Corporate Governance Role of the Media: Evidence from Russia

Alexander Dyck, Natalya Volchkova and Luigi Zingales

NBER Working Paper No. 12525

September 2006

JEL No. G3, O16

\begin{abstract}
$\underline{\text { ABSTRACT }}$
We study the effect of media coverage on corporate governance by focusing on Russia in the period 1999-2002. This setting offers us three ideal conditions for such a study: plenty of corporate governance violations, no alternative mechanisms to address them, and the presence of an investment fund (the Hermitage) that actively lobbies the international press to shame companies perpetrating those violations. We find that Hermitage's lobbying is effective in increasing the coverage of corporate governance violations in the Anglo-American press. We also find that coverage in the Anglo-American press increases the probability that a corporate governance violation is reversed. This effect is present even when we instrument coverage with an exogenous determinant, i.e. the Hermitage's portfolio composition at the beginning of the period. The Hermitage's strategy seems to work in part by impacting Russian companies' reputation abroad and in part by forcing regulators into action.
\end{abstract}

Alexander Dyck

University of Toronto

Joseph L. Rotman School of Management

University of Toronto

105 St. George Street

Toronto, Ontario

CANADA M5S 3E6

adyck@ rotman.utoronto.ca

Natalya Volchkova

Nakhimovsky pr., 47, Office 720

117418 Moscow

RUSSIA

nvolchkova@cefir.ru
Luigi Zingales

Harvard University

Littauer Center

Cambridge, MA 02138

and NBER

luigi.zingales@gsb.uchicago.edu 
In recent years, hedge funds have emerged as some of the most powerful players in corporate governance worldwide. From the dismissal of Deutsche Boerse’s CEO Seifert to McDonalds spin-off of major assets in an IPO, hedge funds have played a crucial role. The Wall Street Journal labeled them the "new leader" on the "list of bogeymen haunting the corporate boardroom." ${ }^{\prime}$ Among the many tactics hedge funds managers use, the most prominent one is to focus public attention on an underperforming company and shame the CEO to either resign or change policy (Kahan and Rock, 2006).

It is hard to tell, however, whether this public relations campaign is just a smokescreen for more important maneuvers that take place behind the scene or is a crucial ingredient of their battle. Can hedge funds (or shareholders in general) increase the level of coverage received by certain news/companies? And if so, does this coverage have any effect on corporate governance outcomes? These questions are hard to address using U.S. data. On the one hand, most hedge funds trade in and out of companies very quickly. So it is hard to disentangle whether they are simply good at recognizing that the situation is ripe for change or whether they are indeed an actor of change. On the other hand, hedge funds in the United States (and in most of Europe) have access to an array of options to address bad corporate governance (from shareholder's suits to calling an extraordinary general meeting). So it is hard to tell whether they succeed because of their public relations campaign or because of the power of their legal rights.

To overcome these problems we study shareholders' ability to influence coverage and the impact of this coverage on corporate governance by looking at Russia. Russia presents a useful laboratory setting for this analysis for several reasons. First, during the late 1990s, corporate governance violations in Russia were very extreme, very common, and very visible, providing a wide field of inquiry. Second, in Russia, the standard mechanisms to readdress these violations were either non-existent or completely ineffective (for example, courts were easily corruptible), allowing us to identify whether media have an independent effect on outcomes. Third, and most important, in Russia, there exists an investment fund (the Hermitage Fund), with extremely low turnover, that

\footnotetext{
${ }^{1}$ Alan Murray “Hedge Funds Are New Sheriffs of Boardroom,” Wall Street Journal, 14 December 2005, pg A2.
} 
consciously played a media strategy after the 1998 Russian crisis. In the words of its chairman: "Our basic approach is to thoroughly research and understand where the corporate malfeasance is taking place and then go to great pains to simplify the story so the average person can understand what is going on..... We then share the stories with the press. By doing so, we want to inflict real consequences - business, reputational and financial” (Dyck, 2002). Since the Hermitage fund spends resources only when it has money at stake, we can use the Hermitage's portfolio composition as an instrument for news coverage. To avoid any possible reverse causality, we use Hermitage portfolio's composition at the beginning of the period, before the corporate governance violations take place.

To identify a sample of potential corporate governance violations we exploit the fact that a prominent Russian investment bank, Troika Dialog, produced a weekly publication, between 1998 and 2002, that highlighted all the corporate actions that, in their view, have the potential to severely impact outside investors’ rights. This definition of potential violation does not necessarily imply that any Russian law was infringed. ${ }^{2}$ How to judge, for instance, Tomskneft's dilutive equity issue in 1999? The issue was approved by shareholders present at the meeting. But very few were able to be present because the day of the meeting the company announced that the venue had been transferred to a new distant location that shareholders couldn't possibly reach in time to vote on the proposal.

We refine this list by eliminating repeated events and minor violations (like a delay in financial reporting). We then study how much coverage each of these violations received and whether they were stopped or somehow readdressed.

Not surprisingly, we find that the magnitude of the violation (which we proxy by the potential loss caused by the announced decision) increases the extent it is covered in the Anglo-American media. We also find that, controlling for the severity of the violation, companies receiving more coverage in normal periods (and thus more newsworthy) command more attention. Even controlling for these factors, however, we

\footnotetext{
${ }^{2}$ When discussing governance violations we focus on the distributional impact. It is harder to make any overall welfare assessment. Even actions that have an extremely negative distributional impact (such as pure theft) can have a positive efficiency effect, because the consolidation of cash flow rights in one hand
} 
find that the presence of the Hermitage fund among its shareholders increases the amount of coverage a corporate governance violation receives. This correlation does not appear to be due to the Hermitage fund's ability to pick newsworthy companies, since the effect is present even when we use the Hermitage Fund's stake in companies at the beginning of the period (end of 1998).

We then test whether news coverage in the Russian and prominent English language press surrounding and following the revelation of this potential violation is correlated with the eventual outcome. We find that the probability the decision negatively impacting outside investors is reverted is significantly affected by the coverage of the event in Anglo-American newspapers, even after controlling for other potential determinants of the outcome, such as the degree of foreign ownership and the involvement of international organizations such as the European Bank of Reconstruction and Development (EBRD). By contrast, exposure in the local press has no impact.

Between the two main foreign newspapers, the Wall Street Journal seems to have more impact than the Financial Times. This could be the result of a higher credibility of the former or of the different importance of the two types of audiences these newspapers have. To separate the effect of audience from that of credibility, we use a Russianlanguage publication called Vedemosti. Since this publication is a joint venture between the Wall Street Journal and the Financial Times, it has credibility similar to that of its owners. But being in Russian, it only reaches Russian businessmen and politicians. Our finding that coverage by Vedemosti has no significant effect suggests that the leverage is provided by the reputation vis-à-vis the Anglo-American community.

So exposure of corporate governance violations in the international press seems to promote some readdress. This evidence hardly proves that the press was an instrument of change, let alone that hedge funds were the force behind this change. An egregious corporate governance violation is more likely to be covered by newspapers regardless of any effort by hedge fund managers. And such an egregious violation is also more likely to generate a reaction. To attempt to disentangle these effects, we instrument foreign press coverage with the Hermitage Fund's stake in companies at the end of 1998. Since

can have positive incentive effects as argued in the Russian case by Shleifer (2005), and Guriev and Rachinsky (2005). 
the Hermitage fund will only spend resources in lobbying the press if it has some skin in the game, Hermitage's stake can be considered a good measure of the exogenous component in news coverage. When we instrument coverage with this exogenous determinant, its estimated impact on outcome does not change, suggesting this link might be causal.

Finally, we investigate the main mechanism through which the press had an effect. We find that, in roughly half of the cases, media pressure leads a regulator or a politician to intervene, while in the remaining half, it is the company itself that relents, realizing the reputational costs of continuing the battle. In sum, this evidence suggests that the primary mechanism through which media coverage has an effect is by increasing the reputational cost of misbehavior vis-à-vis a relevant audience (in this case Anglo-American investors).

This paper contributes to the literature on the real effects of media coverage. Previous work has looked at the impact of coverage on the voting behavior of citizens (George and Waldfogel (2004) and Della Vigna and Kaplan (2006)) as well as of representatives (Dyck, Moss, and Zingales, 2005). As Dyck and Zingales (2002, 2004), this paper looks at the impact of coverage on corporate governance. But rather than focusing on a cross-country correlation between newspaper circulation and various corporate governance outcomes, this paper focuses on a within-country setting where we are better able to identify the impact of the press. In this respect, our paper is similar to Miller's (2006), which explores the role played by the media in bringing to light corporate frauds in the United States.

Our paper is also related to the growing literature on the determinants of possible media biases. Previous work has emphasized the biases generated by advertising pressure (Reuter and Zitzewitz, 2003), media ownership (Besley and Pratt (2001)), competition for audience (Baron (2003), Mullainathan and Shleifer (2005) and Gentzkow and Shapiro (2006)), and the quid-pro-quo between journalists and sources (Dyck and Zingales, 2004)). By contrast, this paper looks at the ability of financial institutions, with sufficient 'skin in the game', to influence whether a story makes its way to the international press. 
Finally, our paper is also related to a large literature on shareholder activism. As nicely summarized by Gillan and Starks (2003) and Karpoff (2001), the bulk of this evidence has focused on pension and mutual funds and their attempt to discipline managers with traditional control mechanisms, such as incentive contracts (Almazan, Hartzell and Starks, 2005). By contrast, we follow Kahan and Rock (2006) in studying a new important player (hedge funds) and we focus on an alternative mechanism: shaming in the press. In addition, our use of the Hermitage holdings as an instrument allows us to make further progress towards establishing a causal link between activism and outcomes. A limitation of our study, due to the illiquidity of the Russian market, is that we can only look at specific governance disputes rather than overall share performance.

The rest of the paper proceeds as follows. In Section I we introduce a parsimonious theoretical framework for considering the impact of the media. We start by arguing that the media can matter, as they impact the reputation of the agents involved. In Section II we explain why we focus on the Russian market. Section III describes our research design and data. Section IV studies the determinants of media coverage of major corporate governance violations and the impact that the Hermitage fund has on this coverage. Section V presents our main results on the effect of media coverage on the probability corporate governance violations are addressed. Section VI presents results when we instrument for coverage with the presence of the Hermitage fund. Section VII discusses the mechanisms through which media affect outcomes. Section VIII concludes.

\section{What role can the media play in corporate governance?}

\section{I.1 The role of the media in information diffusion}

The role of the media is to collect, select, certify, and repackage information. In doing so they dramatically reduce the cost economic agents face to become informed. When the Wall Street Journal reports a table with the quarterly performance of mutual funds, for instance, an investor does not have to spend time collecting all the pieces of information herself, but she can glance at them in a second, for the price of a dollar (plus the opportunity cost of the time spent reading). Furthermore, if there is a strong complementarity between news and entertainment, as it is often the case for hot or 
titillating topics, the media can make the cost of absorbing information negative by packaging news appropriately (Becker and Murphy (1993) and Dyck, Moss, and Zingales (2005)).

This dramatic reduction (if not elimination) of the cost of collecting information is very important since, in many situations, individual agents face a rational ignorance (Downs, 1957) paradox: the cost of becoming informed exceeds the benefit they can personally gain from that information. Hence, the media have the power to overcome the “rational ignorance” result (Dyck, Moss, and Zingales, 2005). By doing so, the media increase the number of people who learn about the behavior of other people, thereby increasing the effect of reputation. In the words of Justice Brandeis: "Publicity is justly commended as a remedy for social and industrial diseases. Sunlight is said to be the best of disinfectants; electric light the most efficient policemen.” 3

\section{Which reputation?}

Starting with Fama (1980), the finance literature has recognized the importance reputation plays in disciplining corporate managers. The early literature, Fama (1980) and Fama and Jensen (1986), emphasized managers' reputation vis-à-vis potential employers, who will determine future jobs and wages. Even with recent declines in CEO tenure, CEOs do not hop from job to job frequently. Especially for CEOs of large companies, the probability of re-entering the labor market (and thus the importance of their reputation vis-à-vis future employers) is minimal. By contrast, career concerns might lead directors to act against the interest of shareholders. Since they are appointed by managers, they should care about their reputation vis-à-vis them.

More important, instead, is the role played by a manager's (or a company’s) reputation vis-à-vis financial markets, as modeled by Diamond (1989) and (1991) and Gomes (2000). To the extent a company needs to access financial market repeatedly, its reputation will affect the terms of future financing. Since these terms affect the profitability of a company and its ability to exploit future investment opportunities, they will be important even for self-interested managers.

Managers, however, seem to care not only about their reputation vis-à-vis the

\footnotetext{
${ }^{3}$ Louis D. Brandeis, 1933, Other People’s Money, National Home Library Foundation: 62.
} 
financial market, but also vis-à-vis society at large. As Dyck and Zingales (2002) argue, managers often bow to environmental pressures not because these are in the interest of shareholders, but because they do not want to face the private cost of being portrayed as "the bad guys".

\section{I.2 The role of the media in corporate governance}

Consider a manager who has to decide whether to make a decision that might benefit her personally, but might hurt her reputation and trigger some legal punishment. A simple application of Becker's (1968) model has that a manager will be dissuaded from such an action if and only if

$$
\begin{gathered}
\mathrm{E}(\text { Private benefit })<\mathrm{E}(\text { Reputational cost })+\mathrm{E}(\text { Punishment })= \\
=\left.\sum_{i} p_{i}{ }^{*} R C_{i}\right|_{\text {i learns about it }}+\pi P
\end{gathered}
$$

where $R C_{i}$ is the reputational cost of this action vis-à-vis group $i, p_{i}$ is the probability group $i$ will receive the news about the manager's action and will believe it, $\pi$ is the probability of enforcement, and $P$ is the punishment in case of enforcement.

The media influence the right hand side of this equation in four ways. By publishing the news they can change $p_{i}$, i.e., the probability that a given action is known to a certain audience and so it carries a reputational cost. Of course, different media have different audiences, so each medium has a special impact on its own audience's $p_{i}$. If, for instance, a company is planning to raise new finance and it cares about the capital markets' perception of its own action, it will be very sensitive to coverage in outlets that are read by the financial market community.

The second way in which the media can affect the decision is by increasing the reputational cost $R C_{i}$. When the lavish compensation of the former chairman of the New York Stock Exchange Richard Grasso was revealed by the press, for instance, many of the same directors who approved it changed their position. What triggered this about face was not only the diffusion of this information to a large audience, but also the negative characterization of Grasso's pay package by even the most pro-business newspapers. This 
negative slant increased the reputational cost the directors faced and likely factored into their change in position.

Third, the media can have an impact by changing the probability of enforcement $\pi{ }^{4}$ This impact arises through three channels. The first one is a simple extension of Fama's model to politicians: they care about their future employers, i.e. the voters. ${ }^{5}$ The second channel passes through the role of media in the battle between public interest and vested interests. A major reason why vested interests have so much power in political decisions is because of the "rational apathy" of voters (Downs, 1957). As Dyck, Moss, and Zingales (2005) argue, however, this rational apathy can be overturned by the media. By making political news entertaining, the media can overcome voters' cost to become informed and, in so doing, reduce the power of vested interests. Once again, Richard Grasso's very large compensation became an entertaining news, and made a much larger group of people aware of the potential conflict of interest intrinsic to the position of the NYSE chairman, who is in part a defender of the interests of the NYSE seat owners, and in part regulator. This new awareness substantially weakened the position of the NYSE lobbying effort to maintain its monopoly position. The third channel arises because politicians do not care only about reputation vis-à-vis voters, but also their reputation (and their country's reputation) vis-à-vis foreign countries. Russian President Putin, for example, also cares about his own reputation vis-à-vis the Western world and, in particular, the United States. Any news (especially if reported in the international press) that makes him appear weak or not in control of the situation undermines his credibility in the international circle. Therefore, he will be more likely to take an action to address a problem if this problem is visible to the international community.

In sum, in the face of a corporate governance violation, a regulator who has to decide whether to intervene faces a trade-off very similar to equation (1). On the one hand, the private benefits of not enforcing are represented by the effort saved and the

\footnotetext{
${ }^{4}$ The large literature on law and finance has emphasized the importance of legal enforcement as different from the law on the books (La Porta et al. , 1998; Bhattacharya and Daouk, 2002), but has not explored what drives enforcement. As the discussion below suggests, media pressure can be an important determinant of legal enforcement.
} 
gratitude acquired from the company committing the violation. On the other hand, the regulator faces some reputational cost for being perceived as ineffective in her own job. In addition she faces the risk of a punishment, if her inaction violates a law and if this law is enforced. By diffusing the news of a corporate governance violation, the media expose the regulator's lack of activity, increasing the personal cost of her inaction. The SEC, for example, started to ask the NYSE board about its compensation practices after the first news of Richard Grasso’s compensation was published in the Wall Street Journal. The publication of that news informed many people about the issue and created some awareness that the SEC was passive on this front. This awareness was sufficient to spurt the Commission into action.

Finally, the media can affect the right hand side of equation (1) by impacting the size of the penalty $P$. This is definitely true if a case goes to trial, because media can impact the mood of a jury. But it is also true whenever the enforcer has any discretion in the size of the punishment and she is influenced by her reputation vis-à-vis the public at large.

Note that all the terms on the right hand side of equation (1) are ex ante estimates. Hence, what will affect the decision to commit a corporate governance violation is a manager's expectation of the likelihood the relevant players will learn about his decision and how harshly his decision will be judged. After the decision has been made, however, what determines the probability of reversal of this decision is the actual realization of those costs, which is greatly affected by the coverage in the media. Hence, the impact of the media is most visible (albeit not necessarily most important) in environments where managers underestimate ex ante the degree of intervention and influence of the media. As we will explain momentarily, this is exactly the case in Russia.

\section{I.3 When are the media most effective?}

If we look at equation (1), the impact of media is greater when the media reach a larger number of relevant groups (i.e, groups with whom managers care to maintain a good reputation) and when the news reporting generates a greater increase in $p_{i}$. In the

\footnotetext{
${ }^{5}$ This is not strictly true with a regulatory agency such as the SEC where those in charge have no voters to be accountable to. But it is a reasonable approximation, for the SEC relies for its budget and authority on
} 
language of the media, these two characteristics are diffusion and credibility. Ceteris paribus, the more people a medium reaches, the broader will be the reputational impact of its reports. To produce an increase in $p_{i}$, the news must come from a credible source, otherwise it is not believed. If we receive an e-mail coming from an unknown organization that accuses a famous professor of plagiarism, we are unlikely to believe it. If the same news were reported in the New York Times, we would be much more likely to believe it because the New York Times has developed a good reputation (some recent incidents notwithstanding).

Finally, the effectiveness of the media depends upon several characteristics of the surrounding environment. If the relevant reputational punishment occurs in the labor/product market, its magnitude depends upon the frequency of repeated buyers in that market and the ratio between future and current benefits. Reputational penalties are strongest in a market with many repeated buyers. Similarly, reputational costs are bigger when a company needs a good reputation now (i.e, to raise a large amount of funds in the capital market) rather than in the future.

If, by contrast, punishment occurs through social pressure, then its magnitude depends upon the strength of shared social norms. Media can only be as effective as the moral norms shared by a certain community and its media.Exposing a CEO for not maximizing shareholders' value does not have much of an impact in a country where this goal is not shared as legitimate by at least a relevant fraction of society. By contrast, in the United States there is a well-developed set of business publications (representative of a relevant part of society) that share this goal. These publications are the most effective in reaching business people who will interact with executives in the future. Hence, any executive fears being exposed as villain in these publications.

\section{The Russian Case}

\section{II.1 Why Russia?}

If enforcement is very effective and/or legal punishments are extremely severe, the manager's expected cost of violating minority shareholders' rights is such that

Congress, and these political overseers care about political concerns about inactivity. 
managers will never do so. For this reason, it would be very difficult to try to identify any effect of the media in a country with very effective corporate governance rules.

The same is true, however, if the media have a long track record of imposing reputational penalties to managers who violates investors' rights. The fear of these penalties will dissuade any manager from committing a violation. Ideally, thus, we would need a country that has very little or no legal enforcement and where, at the time a decision is made, the reputational costs of a decision are perceived to be very low.

Russia during the period late 1990s-early 2000s scores "well” on both dimensions. During this period the standard instruments to readdress corporate violations were either non- existent (derivative suits) or completely ineffective (for example, courts were easily corruptible, see Slink, Yakolev, and Zhuravskaya, (2004)). As a result, corporate governance violations were very extreme, very common, and very visible. Hence, we can relatively easily assemble a sample of objectively bad governance decisions and follow them over time.

At the same time, Russian managers were just starting to learn how to deal with the press, in particular with the foreign press. Having been raised in an environment (Soviet Russia) where the media were reporting only what the party establishment wanted, they were unlikely to factor into their decisions the reputational cost the media could inflict.

No one illustrates this learning process better than Khodorkovsky, the former CEO of Yukos. At the beginning of his career, Khodorkovsky hated the press and kept it at distance. After one of his rare meetings with journalists, he declared: "It would be more pleasurable to meet a bunch of our unpaid workers in Siberia." ${ }^{6}$ In August 1999, however, when the Bank of New York was accused of laundering money for several Russian companies, Yukos changed strategy, because it was concerned that "despite the absence of specific data, U.S. officials have taken the publications quite seriously -- a U.S. Congress hearing is scheduled for mid-September. A possible result of this hearing could be a decision to refuse Russia the financial aid of international financial institutions."7 Such attention spurred Yukos to hire a Western public relations agency and

\footnotetext{
6 “Oily Charm”, The Economist, 5 December 1998.

${ }^{7}$ Yukos Press release as reported by PR Newswire, 30 August 1999, 03:37 PM.
} 
to start to fight back all the allegations in the media. Explaining Yukos decision to keep his company public and to pay more attention to investors and public relations, Khodorkovsky said: "First, there are not many very big private companies - and we want to be very big. Second, we need access to cheap capital and that means openness. Third, a big oil company has lots of workers, lots of ecological responsibilities. If it is opaque it is not going to be popular. Finally, there is the issue of nationalisation, which we can never ignore. A private company is a lot easier to nationalise than a public one." ${ }^{8}$ Following this public relations campaign, Yukos started to be praised in Western media as a model of financial transparency and Khodorkovsky became the darling of the Western press. While this strategy was not sufficient in preventing Putin from seizing Yukos, it certainly made it more costly for him to do so.

As Khodorkovsky quotes suggests, Russians care about their reputation vis-à-vis the international community for three reasons. First, they might want to access international markets (for financing, joint ventures, and even sale contracts). Second, as an insurance policy, both to protect the legitimacy of their holdings and to facilitate an asylum request in case they become persecuted in Russia. Third, for personal satisfaction. After becoming rich, executives in many developing countries seek broader acceptance in the international community by joining the World Economic Forum at Davos, seeking positions on the boards of trustees of prominent international institutions, and so on. Negative news reported in international media can also have the effect of ostracizing the executives from these desired social circles. While the Russian oligarch Vladimir Potanin was successful in his efforts to join the trustees of the Guggenheim Museum in April 2002, Oleg Deripaska was “disinvited” from participating in the Davos meeting, and was stripped of his designation as "one of the global leaders of tomorrow” following negative press coverage of civil lawsuits alleging bribery, money laundering, and worse (Financial Times 2001; Wagstyl 2002). ${ }^{9}$

\footnotetext{
${ }^{8}$ Robert Cottrell and Arkady Ostrovsky: “After the oligarchs,” Financial Times, 16 April 2001.

${ }^{9}$ One way to reconcile this effect with the traditional reputation effect is to posit that every manager has the option to start a political career and, thus, she cares about her general reputation. But since a political career is not a source of large monetary gains, the existence of such an interest can be justified only with an extra term in the utility function. It is simpler, then, to posit from the beginning that managers care about their reputation in this broader sense.
} 


\section{2 Can we identify an exogenous shift in news coverage?}

In addition to the two factors mentioned above, Russia provides an excellent environment to identify the impact of the press on governance, because there exists a fund that consciously plays a media strategy: the Hermitage Fund.

Founded in 1996 as a generic hedge fund with a Russian focus, the Hermitage Fund changed its strategy and focus after the 1998 Russian crisis. In the words of its chairman: "Our basic approach is to thoroughly research and understand where the corporate malfeasance is taking place and then go to great pains to simplify the story so the average person can understand what is going on. One of the reasons that certain companies have gotten away with various violations in the past is that no one really understood what was happening because the stories were so complicated. We then share the stories with the press. By doing so, we want to inflict real consequences - business, reputational and financial” (Dyck, 2002).

In explaining why his strategy is successful in increasing coverage, he says:

"You have to understand that the press doesn't know about the stories, have the ability to understand some of these complicated activities, or can't afford to do research. We have a lot of money invested. We are affected. We can devote the resources to do what it takes to truly understand what is going on. Our goal is to frame the issue so that it is clear to everyone what has happened. We do talk to the Russian press, but our focus is on the international press" (Dyck, 2002, emphasis added).

Since the Hermitage fund focuses on generating coverage in those companies where it owns shares, the presence of the Hermitage fund among the shareholders of a company should represent an exogenous shift in news coverage, which can be used to identify the causal mechanism between news coverage and governance outcomes.

\section{II.3 Does Hermitage generate news?}

For Hermitage to produce an exogenous shift in coverage, it must not only want to generate coverage, but also be successful in doing so. In talking with its chairman, we identified two mechanisms the fund has used: to be a helpful source and to become news.

\section{1) Being a helpful source}


One mechanism whereby Hermitage generates news is to conduct research and then present and document this information to a selected group of reporters. Becoming a source for information has the immediate effect of providing the specific news Hermitage wants to present and determining the time of the release of the news.

To illustrate the impact of Hermitage on news coverage, consider the coverage Gazprom, Russia's largest company, received regarding some related-party transactions. There had been widespread concerns about Gazprom's deals with related parties, but this became a focus of attention (and was finally addressed seriously) only when Hermitage provided crucial information to the press. In the words of Bill Browder, head of the Hermitage fund:

My head of research was able to buy the entire Moscow registration database from a hawker on a street corner. With the securities commission database, we knew the names of the companies that stole assets from Gazprom, and with the registration chamber data, we knew which individuals owned the companies. From that we were able to piece together exactly how much was stolen and by which members of management. ... [We] decided to share our findings with the world by selectively releasing different examples of the graft to the major Western newspapers in Moscow. (Dyck (2002))

By October of 2000, Hermitage had put this information together in a 41 page PowerPoint presentation that laid out the story they wanted told, and presented the underlying information, including the sources. As Table 1 shows, there is a clear overlap between their information and resulting stories.

Not only did Browder present new information in his continuing campaigns, he also worked hard to time the presentation of information, and to ensure continued coverage of stories they cared about.

Originally, we would give one reporter the whole story. They would want to check every bit of it out, get the other side's point of view, or ignore it, seeing this as too complicated and time consuming to pursue. Now we give a small piece of the story to a journalist and let them know that we'll give it to someone else in three days if they don't write anything. It seems that journalists are more concerned about losing the story to a competitor than almost anything else. (Dyck (2002))

Suggestive of the success of this strategy, we also see continued coverage of these allegations in the international news, as well as successful outcomes. Concrete steps were 
taken to limit the dilutions of Gazprom, including new requirements for board approval, new audits of these related party transactions, and the removal of the chief executive at the center of these allegations. Panel B of Table1 provides a timeline of these outcomes. It also shows that this story, unlike so many other allegations of shareholder violation in Russia, did not die, but rather was repeated again and again over the next 6 months.

\section{2) Becoming news}

Another channel through which Hermitage generates news is by becoming news, filing a lawsuit. As Bill Browder argues,

We also go to courts. We've been involved in 32 lawsuits. And we win in terms of public attention regardless of the outcome, where we've lost 31 times. I think the proportion of number of words written in the press when a lawsuit is initiated to when it is dismissed is 50 to 1 . The court of public opinion is much more effective than the Russian legal system and much fairer. (Dyck (2002))

The case of Sberbank illustrates this channel. At the end of 2000, the Sberbank board announced plans to go forward with a new share issue, which had the potential of diluting the ownership stakes of existing shareholders. It was hard for shareholders to fight against this decision using traditional methods, since there were no representatives of minority shareholders on the board. Hermitage, instead, chose to launch 12 different lawsuits against Sberbank and the Central Bank. Although the lawsuits were all dismissed, they generated a large amount of publicity, which came at a time when the Russian Duma was debating a new law on investor protection. Panel C of Table 1 illustrates the various lawsuits brought by Hermitage and the companies involved. ${ }^{10}$

Not only a lawsuit is news itself and induces newspapers to write about an issue, it also allows journalists to write about it without any fear of being sued for libel. If a journalist writes an article about dubious related party transaction, he might get sued by the company. But if he reports the same facts as the allegation made in a legal case, he incurs no risk. And this is a concern, since the first reaction of many Russian oligarchs to

\footnotetext{
10 The difference in the proportion of successful suits between Browder's quote and the table stems from two factors. First, in the quote Browder is referring to domestic Russian suits. Second, the table includes additional recent lawsuits that had not been initiated when the quote was made..
} 
the bad Western press was to sue the journalists that wrote the articles in the court of London, a court more favorable to the plaintiff in libelous cases.

\section{II.3 Selection vs. causality}

For marketing purposes, hedge funds have an obvious interest in self-promotion. To justify hefty management and performance fees to their own investors, hedge fund managers have to claim they have a strategy that adds value. For this reason, we have to be suspicious of Hermitage's claim to be so successful in exposing corporate governance violations in the international press. To this purpose in section V.2 we will test whether it is indeed true that the presence of Hermitage as a shareholder leads to more coverage, after controlling for a series of companies’ characteristics.

Yet, finding such a correlation is not necessarily evidence of a causal link. An equally plausible explanation is that Hermitage buys into companies that are more visible or when it knows they will receive more attention from the press.

To minimize this concern, we chose to use the earliest Hermitage portfolio composition we have available, i.e. December 1998. This predates the major wave of corporate governance violations following the Russian crisis, and hence could hardly be thought as the result of an active strategy to pick more media sensitive companies. It also predates the period when Hermitage actively used the press as part of its strategy to increase returns in its portfolio.

\section{Data Description}

\section{III.1 The sample}

Ideally, we would like a complete sample of corporate governance violations during a certain period. Fortunately, between 1998 and 2002 Troika Dialog, a prominent Russian investment bank, published the Bulletin on Corporate Governance Actions. This bulletin, usually averaging 8-10 pages in length, provided extensive coverage of all companies in Russian capital markets. It contained a one to two paragraph description written by specialists at Troika of corporate actions that came to their attention over the previous week. The Bulletin ceased publication in July 2002 as a result of the heavy 
lobbying done by Troika Dialog's clients, who did not like the negative publicity generated by the Bulletin.

We read all sections in each issue of the Bulletin for the period December 4, 1998 to July 22, 2002. We focused primarily on the events reported in a sub-section titled "Reported/Potential Governance Violations". But we also looked at other sub-sections, such as "New Share Issues" and "Split/Swap /Conversions", and include an event whenever the paragraph description raised concerns that the proposed action would have a negative impact on the cashflows or voting rights of investors. This search resulted in a sample of 480 events.

We then refined the sample introducing a number of additional criteria. We eliminated all events that update earlier mentioned events, and dropped obvious minor events (e.g., minor delays in reporting) to arrive to 201 non-repeat potentially serious governance violations. We then read the English and Russian press to learn more about these events. We used this additional qualitative information to eliminate: (a) minor events, e.g., directors recommend one dividend level and AGM recommends another (32 observations); (b) events that we discovered upon further reading were not initiated by insiders but rather by government actions, e.g., the State blocks a shareholder from getting seats commensurate with his ownership stakes citing security concerns) (47 observations); (c) 24 additional observations where we were still left with uncertainty about the nature and severity of the potential violation. The remaining 98 events form the core sample for our study. In the Appendix we provide more details on this initial screening. Table 2 reports a brief description of the alleged violations in these events and the date as reported by Troika, with the exception of the few cases in which we found an earlier news report in our reading of the Russian and English-language press. Table 3 defines the other variables used in the empirical analysis and reports their sources.

Reading all these allegations, we groups the different strategies used in seven categories. The first groups all attempts to disenfranchise shareholders. This was done through a variety of mechanisms: threatening investors with imprisonment or worse if they don't go along with wishes of controlling shareholders, not allowing shareholders to vote their shares, changing the venue at the last moment to make it impossible for 
shareholders to vote, and making decisions to sidestep shareholder approval for corporate transactions.

The other six categories groups different methods to dilute the cashflow rights of minority shareholders. The first popular method consists in large share issues reserved to insiders at deep discount vis-à-vis the current market price. The second method consists of a share swap between companies and subsidiaries on terms that are viewed as hurting the interests of minority shareholders. The third method involves a reorganization of the firm and its subsidiaries that provides increased scope for self-dealing transactions. The fourth method involves debt holders using bankruptcy proceedings to reallocate assets to themselves, and in so doing diluting minority investors. The fifth method involves selling assets or business opportunities to companies closely affiliated with management. Finally, we include a sixth category, 'other', that captures other ways in which controlling shareholders dilute controlling shareholders. Table 4 identifies the type of alleged violations for each event in our sample.

\section{III.2 Performance measures}

To measure the impact of media pressure on the ability to contain or overturn the corporate decisions that violated minority shareholders' rights, we look at the actual outcomes. After reading the Russian and the English language press over the subsequent year, we coded an outcome as 0 if the initial decision went through as planned and there were no governance changes in the firm linked to the (possible) furor surrounding this event. We coded an outcome as 2 if the proposed violation led to a significant response in the firm (11 istances). This includes reverting the initial decision, introducing significant changes in the terms of the transaction, or approving structural governance changes that makes further such actions unlikely (e.g. change in CEO, change in charter, change in number of independent board members, change in national law). We code an outcome as 1 if there is a partial redress of the shareholder concerns (17 cases). Overall, there was a (partial) positive outcome in $29 \%$ of the cases.

We thought to use the long-term performance of the stock price as a measure of the outcome. We discarded the idea for three reasons. First, the paucity of actively traded companies dramatically reduces the sample. Second, the timing of the possible reversal 
(stretching over months) make it difficult to identify out-performance, especially in an environment, such as the Russian one, characterized by high volatility in stock prices. Last but not least, if the market is so rational to anticipate the impact of media, the stock price performance will underestimate their effect.

\section{III.3 News measures}

Table 5 reports the news coverage of the 98 companies in our sample. The arguments exposed in section I suggest that we have to distinguish between three categories of the press: Russian media published in the Russian language, which have access to the Russian public but have limited credibility ${ }^{11}$; foreign-owned media in the Russian language, which have access to the Russian public but enjoy greater credibility; Anglo-American media, which have access to the international centers of economic and political power, where English is the lingua franca, and enjoy greater credibility.

For the Russian language press we focus on three large and/or prominent newspapers: Kommersant, Izvestia, and Vedemosti. We consider Vedemosti, to be the most credible as it is jointly published by the Wall Street Journal and by the Financial Times. For the English language news, we focus on the Financial Times and the Wall Street Journal as credible western news outlets. We measure the news coverage of the violation in a window surrounding the announcement of the event ( $\mathrm{t}-1$ to $\mathrm{t}+2$ months). We use the period pre-dating our definition of announcement date to allow for the possibility that we may have misspecified the announcement date, particularly since the Bulletin is only a weekly publication. Our results are robust to just including $t$ to $t+2$ months. For the most part we focus on the combined coverage in the English (Russian) press, although we also break down coverage by publication.

\section{III.4 Reputation measures}

Since, in Russia, all legal remedies are very weak and the large shareholders are widely considered the villains rather than the monitors, an important source of restraint is

\footnotetext{
${ }^{11}$ As Mikhail Lesin, formerly President Putin's Media Minister, described it, Russian language media are characterized by ““information wars," which saw oligarchic groups trying to destroy each other through the media, ultimately causing the media's authority to dwindle and undermining trust in the written word.”

February 24, 2005, "Protection and the Media", RussiaProfile.org.
} 
given by the reputation these companies have vis-à-vis foreign investors. We try to capture the scope of such reputation concerns through two proxies: the percentage of equity owned by foreigners and the presence of the European Bank of Reconstruction and Development (EBRD) among the company’s lenders.

We obtained the EBRD investment information from the EBRD publication for Russia, “EBRD Investments: 1991- 2004” and indicate with a dummy if the EBRD had an investment prior to the commencement of the potential governance violation. We obtained the foreign ownership data from a variety of sources, starting with the official recording of the identities of all shareholders with more than 5 percent stake, collected by the Federal Commission on Security Market Disclosure project. In almost all cases, this was insufficient as many owners of record are shell companies with unclear ownership structure (e.g. Cypress based companies) and/or are nominal owners (e.g. Citibank) without further information. We complemented this information with accounts in the business press (Russian and English) and in Troika Dialog "Bulletin on Corporate Governance Actions.” Recognizing the noise in this measure, we also assembled an alternative measure of foreign interest in the stock, which is a dummy variable that takes the value 1 if Troika Dialog collected and reported governance scores for the company sometime in the period from 2000 to end of 2002. It was time consuming and expensive to assemble such scores and Troika would only do so for companies with significant foreign investor interest. Below, we report results using the continuous measure of ownership, but the results are robust (and statistical significance strengthened), if we use this alternative indication of foreign interest. Foreign ownership and the EBRD dummy are reported in Table 6, while Table 7 presents the summary statistics of the variables used in the subsequent regression.

\section{III.5 Other controls}

Other factors may affect the probability of reversal of a corporate governance violation. The nature of the violation itself, for example, can make it more or less reversible. To this purpose, as noted above, we have classified all the corporate governance violation into 7 categories. 
Another factor that might influence the reversal of a corporate governance decision is the size of the potential loss inflicted to investors. To this purpose we create a variable measuring the maximum amount of potential dilution of shareholders' value as a result of this decision. Specifically, for the companies where the potential violation is one of the six categories of dilution, we calculate what the loss would be, were the dilution to go through and this would lead to the worst outcome for minority shareholders.

For example, with new share issues at a very low price to company insiders, we know the number of shares issued and the price at which they are granted so we can straightforwardly calculate the percentage change in the minority shareholders' claim over the firm's cashflow. As an illustration, if the minority shareholders held 10 percent of the firm, and insiders issued 100\% more shares at a zero price to insiders, then minority shareholders claims would now be for only 5 percent of the firm and would see a $50 \%$ dilution in their claim.

Sometimes this maximum percentage loss calculation involves more assumptions, as in the cases of bankruptcies or reorganizations. We made these assumptions based on the practices in Russia at the time, when solvent companies were pushed into bankruptcy and they valuable assets stripped at knock-down prices. On the bases of this fear, for instance, we set the maximum dilution for Chernorgorneft at 100 percent, since its main creditor had the possibility to force the viable oil producer into bankruptcy where it could transfer of all valuable assets to itself at knock-down price, leaving nothing but debts to the shareholders.

We found it much more difficult to identify the maximum possible loss for shareholders in those violations that we categorized as disenfranchisements, since these were usually the first stage of a longer process that could deprive shareholders of significant rights and returns. Here, we used our judgment to classify disenfranchisements into three categories, from most severe (coded as a’3') to least severe (coded as a ' 1 ').

Finally, the probability of reversal of a corporate governance violation can be affected by the visibility of a company. Visible companies are more likely to get the attention of the press regardless of any intervention of hedge fund managers and this attention may pressure these companies into reversing their decisions. As proxies for 
visibility we use a measure of size (the logarithm of the book value of fixed assets in 1999), a dummy for oil and gas industry (by far the most important and internationally attractive sector) and the "natural" newsworthiness (the number of references to this company in the Wall Street Journal and the Financial Times during the 6 month period from January to end of June 1998, a time preceding our sample period and prior to the unique period surrounding the Russian default). In controlling for these variables we are going to underestimate the effect of the press. Nevertheless, we include these variables to isolate the causal link.

\section{What Determines News in the International Press?}

As we will see in the next section, the type of news coverage that influences governance outcomes is coverage in the international press. But what determines news in the international press? We address this question in Table 8 , where we analyze the determinants of press coverage. As a dependent variable, we use the natural logarithm of 1 plus the number of articles that appeared in the FT and WSJ around the event windows.

To explain a company's coverage by Anglo-American newspapers, we need to capture the intrinsic interest Anglo-American readers have for these companies. Oil companies, for example, attract much more interest than domestic car manufacturers. Similarly, larger companies tend to have more following than small ones. To capture these dimensions, we insert a measure of size and a dummy for the oil and gas industry.

A second potential driver of coverage in the international newspapers is the percentage of a company owned by foreigners and the presence of the EBRD among its lenders. Hence we control for both these variables.

Even controlling for all these variables, it is not obvious that we have captured the different level of "newsworthiness" of different companies. A candy factory called "Red October" might intrinsically make a better story than an oil company with an unpronounceable name such as Orenburgneft. To measure this otherwise difficult-tocapture effect, we compute the natural logarithm of one plus the number of articles present in the foreign press during a quiet period before the Russian crisis (i.e., between 
January first and June 30 of 1998). ${ }^{12}$ Finally, to capture the different intrinsic newsworthiness of different corporate governance violation, we insert dummies for the seven different types of violations and a measure of the intensity of this violation.

As column 1 shows, the two main determinants of coverage are the size of the firm and the "natural" newsworthiness. Together they explain $47 \%$ of the variation in coverage. In column 2 we insert as an additional explanatory variable: the percentage of a company owned by the Hermitage fund at the end of the 1998 from the Hermitage consolidated financial statements ${ }^{13}$ If our conjecture (and the claims of the Hermitage Fund chairman) is correct, the level of coverage should be higher when the Hermitage Fund owned a stake, because it has an incentive to intervene and prompt journalists to write stories. The Hermitage ownership variable enters in a positive way and it is statistically significant at the $5 \%$ level. One standard deviation increase in this variable almost doubles the expected level of coverage, raising the explanatory power of the regression to $53 \%$.

In columns 3 and 4 , we test whether the Hermitage presence has more effect on the WSJ or on the FT. The estimate of the impact of the Hermitage on the WSJ is twice as large as the one on the FT, and, given the paucity of data, this is not statistically significant for the FT while it is significant at the $1 \%$ level for the WSJ.

\section{The Effect of Media on Outcomes}

The second question we try to address is whether press coverage has any impact on the probability that a corporate governance violation is partially or completely addressed. The simplest way to test whether news coverage makes a difference is with a non-parametric test. Since the biggest difference is between companies whose violation is reported in the international media (17 of the cases) and violation that do not get reported, in Table 9, we split the sample along this dimension. 59\% of the violations covered by international media are reverted against a mere $22 \%$ of the violation that are not covered.

\footnotetext{
${ }^{12}$ We also explored an earlier period, July 1, 1997 to December 31, 1997 and found a very high correlation (.966) between the two measures and that our results are strengthened with this alternative measure.

${ }^{13}$ This is the earliest financial statement we have available. For the 5 companies with an event before December 1998 we use the December 1998 holdings unless we know from the financial statement when the stake was acquired or disposed. We checked that our results are robust to dropping these 5 observations.
} 
A Mann-Whitney test rejects that the two distributions are the same at the $1 \%$ level, $(\mathrm{p}=.0025)$. The same approach tells us that the Hermitage fund enjoys a much better record of reversal among its portfolio companies than average: $45 \%$ successes in the companies owned versus $24 \%$ success in the companies he did not own.

Of course, this approach does not factor other possible differences between the two samples. For this reason, Table 10 repeats the exercise in a standard regression format. In Table 10A (column 1), we present our basic specification. The dependent variable is our measure of outcome (which can be either two, or one, or zero), hence we run an ordered logit. As control variables we insert two proxies for reputation (foreign ownership and EBRD as a creditor), two proxies for the visibility of the company (log of assets and dummy for the oil industry), 6 dummies for the type of violation and a measure of the severity of the violation. For the disenfranchising action, our measure is an ordinal one. For the dilutive issues, it is the maximum potential loss due to dilution. Since the two measures are not homogenous, we insert them in the regression interacted with a dummy for the type of damage inflicted to the shareholders (dilutive or disenfranchising). Since we are able to construct this variable only for 94 companies, the sample is reduced to this number. ${ }^{14}$

Of all these variables, only one (the maximum loss due to dilution) is statistically significant. A one standard deviation increase in the maximum possible loss due to the dilutive decision raises the probability of seeing the corporate governance violation reverted by seven percentage points.

The lack of significance of all these variables is not too surprising. A rational manager will only commit violations he thinks he can get away with. So if the probability of having to revert the decision is significantly higher for certain types of violations, rational managers should commit fewer of those. Similarly, if the probability of having to revert the decision is significantly higher for certain companies, the managers of these companies should be more reluctant in abusing their shareholders' rights.

To this basic specification, in column 2 of Table 10A, we add a measure of foreign press coverage (number of articles published in the FT and WSJ in the period one

\footnotetext{
${ }^{14}$ For four observations the violation involves assets where we were unable to assess their market value so were unable to calculate the extent of the dilution.
} 
month before to two months following the event). ${ }^{15}$ Press coverage has a positive and statistically significant effect. One standard deviation increase in the number of articles published in foreign newspapers increases the probability of full redress (outcome $=2$ ) by 14 percentage points. One more article increases this probability by 5 percentage points.

Given the mass of observations with zero coverage, in column 3, we re-run the same specification with a dummy variable for positive coverage instead of the actual number of articles. The result is very similar. In column 4, instead, we use the logarithm of 1 plus the number of articles, which seems to be a good compromise between the two previous specifications. The results are unchanged. ${ }^{16}$

Since we do not have a compelling theory of which news get covered in the international press and which does not, it is possible that the effect of coverage is spurious. Companies that are more interesting to the media, for instance, can also be companies where the shareholders are better able to fight off managers' violations. To account for this possibility in column 5 we add to the previous specification a measure of "natural newsworthiness", which we measure as the natural logarithm of 1 plus the number of articles referring to this company in the Wall Street Journal and the Financial Times during the 6 month period from January to end of June 1998. ${ }^{17}$ All the effect seems to be captured by the actual coverage, not by the newsworthiness.

The distinction between partial and full redress could be considered somewhat arbitrary, hence in the last column of Table 10 we collapse these two categories into one and we re-run the same regression as a logit. The results are virtually identical. The only difference is that we lose one observation since the dummy for violations that take the form of asset stripping perfectly predicts the outcome.

\footnotetext{
${ }^{15}$ We use this longer window to capture the possibility that there might be noise in our identification of the announcement date (e.g. the bulletin on corporate governance actions is issued only weekly). All results are robust to focusing on the narrower window of t to 2 months after the announcement of the proposed infraction.

${ }^{16}$ For simplicity we have presented results using one set of controls. The results are robust to alternative specifications including omitting the severity of infraction variable (which allows us to use all 98 observations), excluding the category of violation, using a more comprehensive set of industry controls rather than a simple oil dummy, using another measure of foreign interest in a stock (Troika Dialog provides company analysis including governance scores) to address possible concerns about mismeasurement of foreign ownership..

${ }^{17}$ We also checked this with an alternative period, July 1, 1997 to December 31, 1997 (correlation =.966 with later period) and found our results to be robust.
} 
In Table 10B, we try to probe deeper into which articles are more important for a positive outcome. Column 1 inserts, as an explanatory variable, the coverage in Russian newspapers (log of 1 plus the combined number of articles in Kommersant, Izvestia, and Vedemosti.) The effect is negative but economically and statistically indistinguishable from zero.

Column 2 decomposes the effect of foreign press coverage between the Financial Times (FT) and the Wall Street Journal (WSJ). The coefficient of the WSJ is three times bigger than that of the FT and it is statistically different from zero (unlike the FT's one). Even correcting for the higher mean and standard deviation of FT articles, the WSJ has more impact: one standard deviation increase in the number of WSJ articles increases the probability of a good outcome by 6 percentage points versus 3 percentage points for FT articles.

One of the Russian newspapers, Vedemosti, is a joint venture between the Financial Times and the Wall Street Journal, with both publishers appearing on the masthead below the Russian name. As such, it should enjoy a reputation similar to that of its owners. On the other hand, by being written in Russian language, it only circulates in Russia. This allows us to distinguish whether the difference in the impact of AngloAmerican newspapers and Russian ones is due to differences in their credibility or in the audiences they have access to.

In Table 10C (column I), we re-estimate the basic specification using, as a measure of press coverage, just Vedemosti (the log of one plus the number of articles published in Vedemosti). The coefficient is negative and not statistically significant. The same occurs in column II, where we also control for the coverage in other Russian newspapers. In fact, the coefficient on Vedemosti is lower than that of the other, less credible, Russian newspapers. Hence, keeping the audience constant, differences in credibility do not seem to have a major effect. Finally, in column III we insert also the coverage in Anglo-American newspapers. While the coefficient on Anglo-American newspapers is positive and significant, the coefficient on Vedemosti remains negative (albeit insignificant). 
In sum, newspapers in Russian, even when credible, do not seem to play much of a role. Hence, we have to infer, consistent with the views of Hermitage's chairman, that the main source of leverage is the access to an international audience.

\section{Addressing the causality problem}

\section{VI.1 Instrumental variables estimation}

There is a potential objection to the results presented in Table 10: more severe violations are likely to trigger more news stories. If it is also true that more severe violations are more likely to be redressed, then our result may be spurious. In part, we have addressed this problem by controlling for the type of violation and the severity of the violation.

But to confront it directly, we now exploit the regressions on the determinants of news coverage described earlier and presented in Table 8. Having identified some exogenous determinants of press coverage, we can now verify whether the effect of coverage on outcome is spurious by using this exogenous factor as an instrument. For comparability reasons, in column 1 of Table 11, we reproduce the estimate of the basic specification using OLS. In column 2, we instrument foreign press coverage with the stake owned by the Hermitage fund in 1998. The IV coefficient remains positive and statistically significant, now at the $5 \%$ level. A one-standard deviation increase in coverage driven by the presence of Hermitage increases the probability that a corporate governance violation is reverted by $50 \%$.

\section{V.2 Other implications}

For some corporate managers to be forced into changing their initial decisions, it must be the case that they were surprised by the intensity of the reaction to their corporate governance violation. If this learning is occurring in our sample, we should observe that the frequency of violations decreases over the sample period. Furthermore, if the Hermitage fund does indeed play a role in boosting the international reaction, the frequency of violation should drop more for companies that have the Hermitage fund among its shareholders. 
To test these propositions we collected a second larger sample. This sample identifies all of the companies mentioned by name in the Troika Dialog Bulletin in all sections during our sample period. This sample of 493 companies includes firms that commit violations, firms against which violations are committed, and firms that are mentioned in passing as part of a discussion of ongoing events in the Russian market. This sample represents the universe of potential firms that Troika could have identified governance violations in.

Armed with this sample, we then identified, for each six month period, whether a violation had been committed, using as our sample of violations the 98 events mentioned above. Since our sample begins in November 1998, the first complete semester starts in January 1999. Figure 1 reports the temporal behavior of these frequencies for the sample of companies owned by Hermitage as of the end of 1998 and for the rest of the companies.

Both curves show a strong negative trend, as implied by the hypothesis that corporate managers learned about the power of the international press during the sample period. The frequency of violations among companies not owned by the Hermitage fund dropped from $4 \%$ to less than $1 \%$. Among companies owned by the Hermitage, this drop was much more pronounced: from $15 \%$ to zero. Hence, companies owned by the Hermitage were much more likely to experience a corporate governance violation at the beginning of the sample period, but not so at the end. This graphic impression is also seen to be statistically significant if we run a linear probability model of corporate governance violation, with company fixed effects, a time trend and an interaction between the time trend and the presence of the Hermitage fund (regression not reported).

\section{How does press coverage lead to better outcomes?}

The question we have not addressed yet is how press coverage succeeds in changing outcomes. In the Gazprom example, the coverage given to the corporate governance violation had several effects. First, the government officials on the Gazprom

board felt compelled to side with minority shareholders and pass a motion that required board approval for any subsequent dilutions. Publication of this news also helped 
coordinate the actions of small institutional shareholders, who demanded an audit of these transactions. These stories inflamed the investment community, and helped Hermitage to convince other investors to sign their proxies to get the necessary $10 \%$ required to demand an independent audit of these and other transactions in December of 2000. The revelations also provided additional motivation for the government to change the CEO of Gazprom in May of 2001.

As this example illustrates, the mechanism through which media coverage affects outcomes is very complex. It is difficult to identify one single force. All the factors that played a role in the Gazprom case seem to have gained strength as a result of news coverage. Nevertheless, we can say that in this Gazprom case, the final difference was made by a political intervention.

Dyck (2002) provides further examples of how media pressure influences political actions, one notable example being the reversal of a proposed dilution by the Russian Securities regulator when Hermitage made the issue sufficiently high profile that he had the freedom to act. As Browder claims,

The reason he made this decision is that I was screaming bloody murder. He had a great scandal on his hands. Nobody had ever taken such a visible and outspoken position. I was shooting from the trenches, and this gave him cover to take his own steps. You have to remember that, as has become clearer since then, oligarchs owned the government and Vasiliev was worried about terrible things happening to him, professionally or even worse. ${ }^{18}$ By not initiating but responding to an attack, he felt more empowered to act. He asked us on a number of occasions to raise specific points in the press because he couldn't go on the offensive until something came out publicly. He was clear that he couldn't be seen as initiating but responding. (Dyck (2002))

With this logic of trying to identify the primary channel which leads to redress (and caveat that all events are complex and open to multiple interpretations) in mind, in Table 12, we try to group the positive outcomes according to the main force behind reversal. Roughly 36\% of the cases reach a (at least partially) positive outcome as a result of the intervention of a regulator. What does press coverage have to do with the decision of a regulator to intervene? By overcoming Downs' (1956) rational ignorance result,

\footnotetext{
${ }^{18}$ Vasiliev resigned from FSCR in October 1999 complaining about a lack of support to address governance violations.
} 
press coverage makes more people aware of the issues involved, increasing the regulator's reputation costs of not acting (Dyck, Moss, and Zingales, (2005)).

Another $14 \%$ of the cases get resolved because of political intervention. If Russia were a typical democracy, the reasoning would be very similar. Politicians feel compelled to intervene on issues that are highly visible, because their political reputation is on the line. Being Russia (and being press coverage in a language not read by most of the voters), the reasoning might be different. The important factor here is the reputation visà-vis foreign (and in particular Anglo-American) investors and policy makers. Even Putin has some concerns about the way he is perceived in the West.

In addition, coverage of certain events by the foreign press might provide political coverage for a Government intervention motivated by other reasons. In the UES case, for instance, Putin took advantage of the negative coverage that his political rival Anatoli Chubais, chairman of UES, was receiving in the Western press and intervened to reduce his power. Had foreign media not attacked Chubais, Putin might have been more reluctant to intervene for fear of the repercussions his actions might have on his reputation in the West.

In another $29 \%$ of the cases, a positive resolution is due to effect of press coverage on the pre-existing opposition. For example, in the Kamaz case, the EBRD was fighting the share dilution approved by the company. Press coverage strengthened the EBRD case because it increased the awareness of investors as to the behavior of Kamaz and in so doing increased the reputation cost of misbehavior.

In the remaining $21 \%$ of the cases, it looks like the company voluntarily changed its course of actions. In these cases it is more difficult to establish what role did press coverage play.

In sum, it looks like the primary mechanism through which media coverage has an effect is by increasing the reputation cost of misbehavior vis-à-vis a relevant audience (in this case Anglo-American investors). Obviously, the success of this strategy is highly dependent on the importance the key actors attribute to their reputation vis-à-vis this constituency.

\section{Conclusions and Implications}


Our paper aimed at establishing two facts. First, news coverage is driven not only by the intrinsic appeal of each piece of news, but also by the lobbying effort exerted by those with an interest in the news being published. Second, media coverage is not just a mirror of reality, but it can have important effects on reality itself, in particular on corporate governance. We show that in Russia, during the period 1998-2002, both these statements are true. The natural question is how generalizable these results are.

There are undoubtedly many characteristics that make this sample unique. First, the Russian situation at the end of 1998. As Figure 2 shows, the Russian default made it extremely difficult for Russian companies to access the international capital market. Eager to return to this market, Russian companies might have been particularly sensitive to their image in the Western press. The ostracism toward Russians is also illustrated by the huge drop in the number of Russians attending the World Economic Forum (Figure 3). ${ }^{19}$ Both these figures show that at the end of 1999, Russia was at the bottom of its international credibility. These contingencies (and the desperate need for foreign aid and capital) might have contributed to Russians’ sensitivity to foreign press coverage.

The second aspect that makes this sample unique is the presence of the Hermitage fund. While a hedge fund, Hermitage takes only long positions, does not turn around its portfolio very much, and is completely invested in Russia. ${ }^{20}$ In this sense, Hermitage is very different from an investor like Kenneth Dart, who fought aggressively against one corporate governance violation, but was happy to let the issue drop when he received a higher payment not enjoyed by other minority shareholders. Being invested in many Russian companies, Hermitage has an interest in developing a reputation of not accepting side deals. Being long makes Hermitage also a credible source of bad news about a company: it has no interest in depressing the stock price. The same cannot be said for many hedge funds.

The third unique aspect of this sample is the naiveté of Russian companies vis-àvis the public relations game at the time. In a more sophisticated environment, a fund like

\footnotetext{
${ }^{19}$ Unfortunately, we were unable to obtain data for the invitees only, so this pattern might be a combination of demand shifts (people being disinvited from Davos as the oligarch Deripaska) and supply shifts (politicians and businessmen not being willing to participate during tough economic times).

${ }^{20}$ Hermitage Fund Consolidated Financial Statements, 1998, 1999, 2000, 2001, 2002.
} 
the Hermitage will find it more difficult to influence the publication of news, because the press is subject to an opposing PR campaign by the company.

Finally, the social context in which Bill Browder, the Hermitage Fund chairman, operates is very special. On the one hand, he is a foreigner who does not belong to the same social circles of the Russian elites and, as a result, does not fear to be ostracized by them for attacking other members of the elite. This gives him much more freedom of action. On the other hand, he operates in a country where the rule of law is very weak, as shown by his need to have a body guard and by the fact that, in November 2005, he was prevented from returning to Russia as “persona non grata”.

Given all these factors, the point estimates obtained in this paper cannot easily be extrapolated to other environments. What can be extrapolated, however, are the two main ideas: news coverage can be effectively manipulated by the parties involved and this manipulation can have real effects on corporate governance. The magnitude of this effect will depend upon the degree of competition among the groups pressuring the media and some intrinsic characteristic of the events that makes them more or less appealing to the press (Dyck, Moss and Zingales (2005)).

Finally, our results carry an important implication for developing economies. As a result of English being the lingua franca in international circles, Anglo American media have an enormous influence on policy making of developing countries, especially countries in need of foreign aid and investment. Since Anglo American media reflect Anglo American social norms and values, these media play a non-minor role in the “Americanization” of values around the world. It is not surprising, thus, that French President Chirac, concerned with the loss of influence of France, has endorsed an initiative for a French CNN that will eventually broadcast also in English. 


\section{$\underline{\text { References }}$}

Almazan , Andres, Jay C. Hartzell and Laura T. Starks, 2005, “Active Institutional Shareholders and Costs of Monitoring: Evidence from Executive Compensation” Financial Management, Vol. 34, No. 4, Winter 2005

Baron, David, 2003, “Competing for the Public Through the News Media,” Stanford GSB Research Paper.

Baron, David, 1996, Business and its Environment, (Prentice Hall: Upper Saddle River, New Jersey.)

Becker, Gary S., 1968, “Crime and Punishment: An Economic Approach, “Journal of Political Economy 76: 169-217.

Becker, Gary S. and K. Murphy, 1993, “A Simple Theory of Advertising as a Good or Bad,” The Quarterly Journal of Economics, Vol. 108: 941-964.

Besley, Timothy, and Andrea Prat, 2001, "Handcuffs for the Grabbing Hand? Media Capture and Government Accountability," London School of Economics and Political Science, London.

Bhattacharya, Utpal, Hazem Daouk , 2002, "The World Price of Insider Trading", Journal of Finance, 2002, vol 57, 75-108

Bhattacharya, Utpal, Hazem Daouk, Brian Jorgenson and Carl-Heinrich Kehr, 2000, "When an Event is Not an Event: The Curious Case of an Emerging Market," Journal of Financial Economics, vol 55, 69-101.

Della Vigna, Steffano and Kaplan, 2006, “The Fox news Effect: Media Bias and Voters,” NBER Working paper, W12169.

Diamond, D., 1989, "Reputation Acquisition in Debt Markets," Journal of Political Economy, August.

Downs, A., 1957, An economic theory of democracy, Harper \& Brothers, New York.

Dyck, Alexander, 2002, “The Hermitage Fund: Media and Corporate Governance in Russia,” HBS case \# N2-703-010.

Dyck, A. and Luigi Zingales, 2002, The Corporate Governance Role of the Media”, in R. Islam ed. The right to tell: The role of the Media in Development, The World Bank, Washington DC, 2002.

Dyck, A. and Luigi Zingales, 2003, “Asset Prices and the Media”, working paper.

Dyck, A. and Luigi Zingales, 2004, “Private Benefits of Control: An International 


\section{Comparison”, Journal of Finance.}

Dyck, A., David Moss, and Luigi Zingales, 2005, “ Media vs. special interests”, working paper.

Fama, Eugene F. 1980. "Agency Problems and the Theory of the Firm.” Journal of Political Economy 88(2): 288-307.

Fama, Eugene, and Michael Jensen. 1983. " Separation of Ownership and Control.” Journal of Law \& Economics 26(2): 301-25.

Gentzkow and Shapiro, 2006, "Media Bias and Reputation,” Graduate School of Business University of Chicago Working Paper.

George, Lisa and Joel Waldfogel, 2003, "Who Affects Whom in Daily Newspaper Markets?” Journal of Political Economy, Vol. 11, pp. 765-785.

Gillan, Stuart and Laura Starks, 2003, "Corporate Governance, Corporate Ownership and the Role of Institutional Investors: A Global Perspective," Journal of Applied Finance, Vol. 13, No. 2, Fall/Winter.

Gomes, A., 2000, "Going Public without Governance: Managerial Reputation Effects”, Journal of Finance, 55 (2), April 2000, pp. 615-646.

Guriev, Sergei and Andrei Rachinsky, 2005, "The Role of Oligarchs in Russian Capitalism,” Journal of Economic Perspectives, Vol. 19, No. 1.

Hamilton, James, 2004, All the news fit to sell, Princeton University Press, Princeton NJ.

Kahan, Marcel and Edward Rock, 2006, "Hedge Funds in Corporate Governance and Corporate Control,” University of Pennsylvania working paper.

Karpoff, Jonathan M., 2001, “The Impact of Shareholder Activism on Target Companies: A Survey of Empirical Findings” University of Washington - Business School

LaPorta, Rafael, Florencio Lopez-de-Silanes, Andrei Shleifer and Robert Vishny, 1998, "Law and Finance," Journal of Political Economy, 1113-1155.

Miller, Greg, 2006, “The Press as a Watchdog for Accounting Fraud,” HBS Working Paper.

Mullinaithan, Sendhil and Andrei Shleifer, 2005, “The Market for News,” American Economic Review, 1031-1053.

Reuter and Edward Zitzewitz, 2003 , "Do Ads Influence Editors? Advertising and Bias in the Financial Media.” Working paper 
Shleifer, Andrei, 2005, A Normal Country: Russia After Communism, Harvard University Press, Cambridge MA.

Slinko, Irina, Yakolev, Evgeny and Ekaterina V. Zhuravskaya, 2004, "Laws for Sale:

Evidence from Russia”, American Law and Economics Review, Vol. 7, pp. 284-318.

Wagstyl, Stefan. 2002. “The Road to Recognition.” Financial Times, April 6/7, p. I.

Zhuravskaya, Ekaterina, 200 


\section{Appendix}

This table shows how we arrived at our final sample based on an initial sample of 480 potential governance violations from the "Bulletin on Corporate Governance Actions" published weekly by the Russian investment bank Troika Dialog, for the period December 4, 1998 to July 22, 2002 (Bulletin \#23\#142). This sample was based primarily on all the events reported in a sub-section titled "Reported/Potential Governance Violations", "New Share Issues", and "Split/Swap/Conversions." The table identifies the criteria for excluding observations, the number of observations removed from the sample, and, where relevant, examples of excluded companies.

\begin{tabular}{|c|c|c|}
\hline $\begin{array}{c}\text { Reasons for excluding } \\
\text { observation }\end{array}$ & Examples & $\begin{array}{c}\text { Number of } \\
\text { observations }\end{array}$ \\
\hline & & 480 \\
\hline $\begin{array}{l}\text { Event is an update of an } \\
\text { earlier mentioned event }\end{array}$ & & 176 \\
\hline \multicolumn{3}{|l|}{$\begin{array}{l}\text { Only reason for inclusion is } \\
\text { that firm has an } A D R \text { in } \\
\text { association with the money } \\
\text { laundering investigation in the } \\
\text { United States }\end{array}$} \\
\hline $\begin{array}{l}\text { Minor delay in financial } \\
\text { reporting }\end{array}$ & & 89 \\
\hline $\begin{array}{l}\text { Identified company is the one } \\
\text { committing the governance } \\
\text { violation. }\end{array}$ & $\begin{array}{l}\text { Yukos, March } 1999 \text { - "Proposed share swap with } \\
\text { subsidiaries causing rift among shareholders" } \\
\text { Sibneft, October } 2001 \text { - "Reverse split scheme comes } \\
\text { under criticism from Noyabrskneftegaz small } \\
\text { shareholders" }\end{array}$ & 14 \\
\hline \multicolumn{3}{|c|}{ Subtotal of non-repeat, potentially serious governance violations $=201$} \\
\hline $\begin{array}{l}\text { Uncertainty - Description of } \\
\text { event presents conflicting or } \\
\text { unclear information that could } \\
\text { not be clarified through } \\
\text { additional investigation } \\
\end{array}$ & $\begin{array}{l}\text { Aphipsky refinery, Sep } 1999 \text { - auction of this asset } \\
\text { owned by Rosneft subsidiary cancelled at last } \\
\text { moment (but unclear why or what is going on here) } \\
\text { Kauchuk, Dec } 1998 \text { - Company in bankruptcy but } \\
\text { some assets slated for auction are seized by creditors }\end{array}$ & 24 \\
\hline $\begin{array}{l}\text { Minor event - Description of } \\
\text { event suggests minor event }\end{array}$ & $\begin{array}{l}\text { Ammonfos, April } 2000 \text { - Directors recommend one } \\
\text { dividend level and AGM recommends another in } \\
\text { apparent violation of law. } \\
\text { Aviastar, April } 1999 \text { - Government report suggests } \\
\text { company should issue shares to dilute and limit } \\
\text { foreign ownership, but rejected by company. } \\
\text { Lensvyaz, Nov 1999, Event highlighted is that } \\
\text { finally pay dividends that promised earlier. }\end{array}$ & 32 \\
\hline $\begin{array}{l}\text { Not valid event - Description } \\
\text { suggests event not a governance } \\
\text { violation initiated by insiders } \\
\text { but rather government action or } \\
\text { action consistent with contract }\end{array}$ & $\begin{array}{l}\text { Kaztransgaz, March } 2000 \text { - appears violation of } \\
\text { contract with western JV partner, (with } \\
\text { compensation) } \\
\text { Krasnoye Sormovo, June 1999- Repeated efforts by } \\
\text { controlling shareholder to get seats on board } \\
\text { commensurate with stakes blocked by state, that } \\
\text { insists on keeping board members given to company } \\
\text { at time of privatization to protect state secrets over } \\
\text { submarine. }\end{array}$ & 47 \\
\hline
\end{tabular}




\section{Figure 1: Evolution of the Frequency of Corporate Governance Violations in Russian Firms}

This figure plots the frequency of governance violations in two sub-samples of Russian firms. The frequency in each semester is determined by dividing the total number of companies classified as corporate governance violators during that semester using companies identified by the Russian investment bank Troika Dialog in their weekly "Bulletin on Corporate Governance Actions," (December 1998- June 2002) by the total number of companies covered by Troika Dialog during the same period. The companies committing violations are those described in Table 2. The first sub-sample consists of the companies where the Hermitage fund had a stake in at the beginning of the sample period (based on their portfolio as of end of 1998), the second one by the rest of the Russian companies followed by Troika Dialog where Hermitage had no stake at the end of 1998.

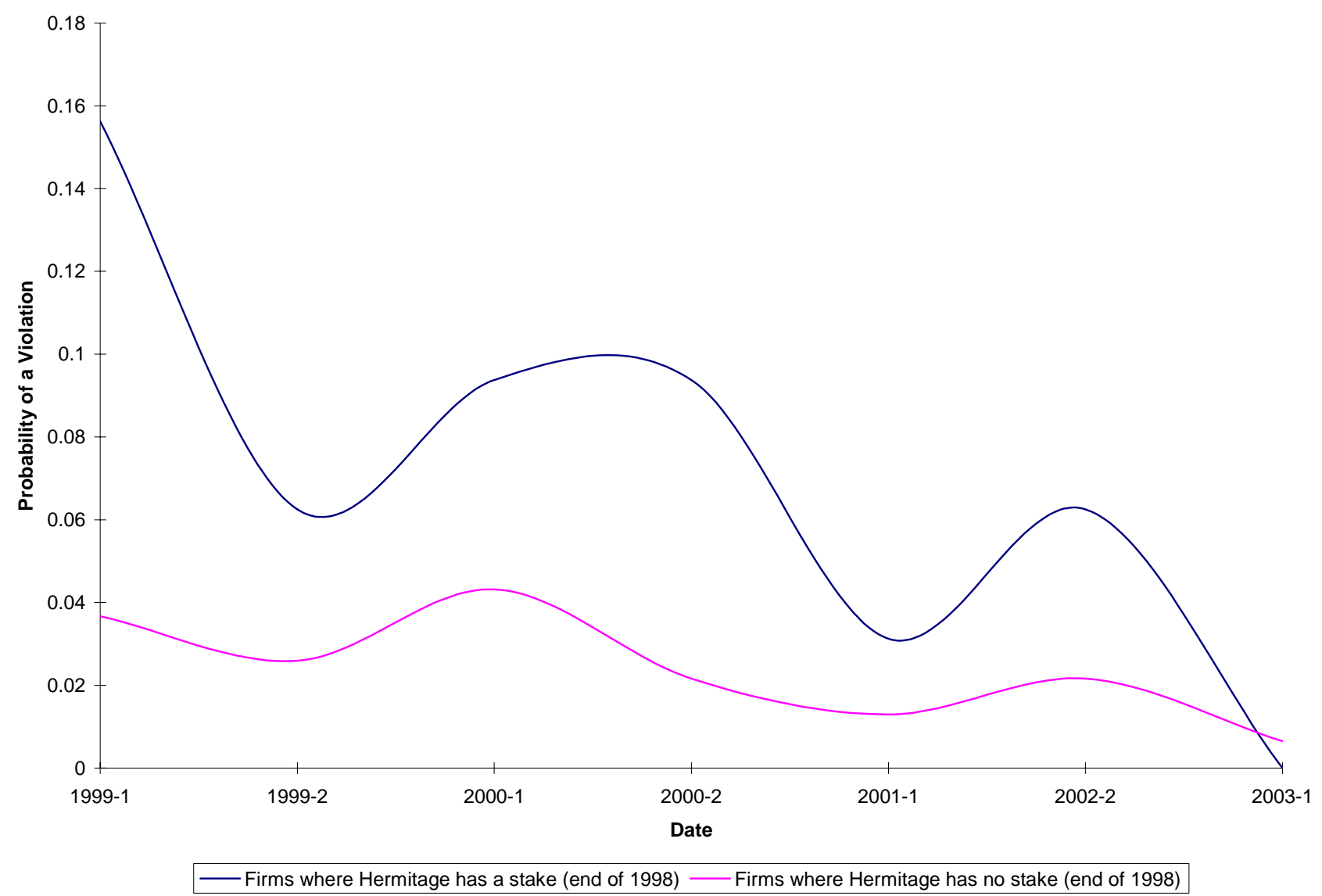

Source: Calculations by based on data from Troika Dialog, Hermitage Capital. 


\section{Figure 2: Russian Bond and Share Issues in the 1994-2004 Period}

This figure plots capital raising in public markets for Russian firms from 1994-2004, based on data on equity issuance and issuance of bonds or notes from Security Data Corporation. The figures are in millions of Euros.

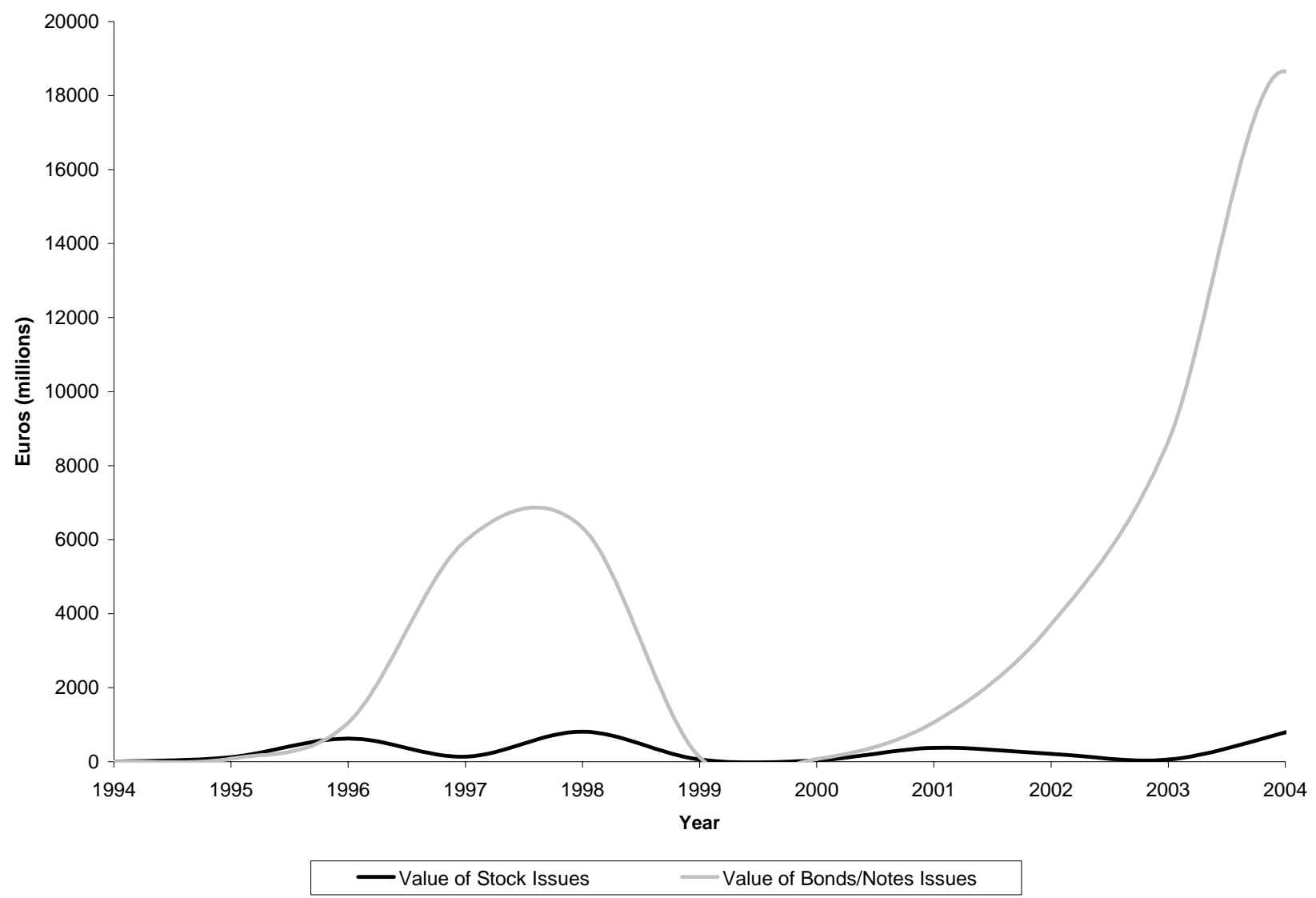

Source: Securities Data Corporation. 


\section{Figure 3: Russian Participants at the World Economic Forum in Davos}

\section{Switzerland}

This figure plots the number of Russian participants in the corporate and public figures categories at the annual meeting at the World Economic Forum in Davos, Switzerland from 1997-2002. These two categories are combined as many figures had positions in both the private industry and the public sector.

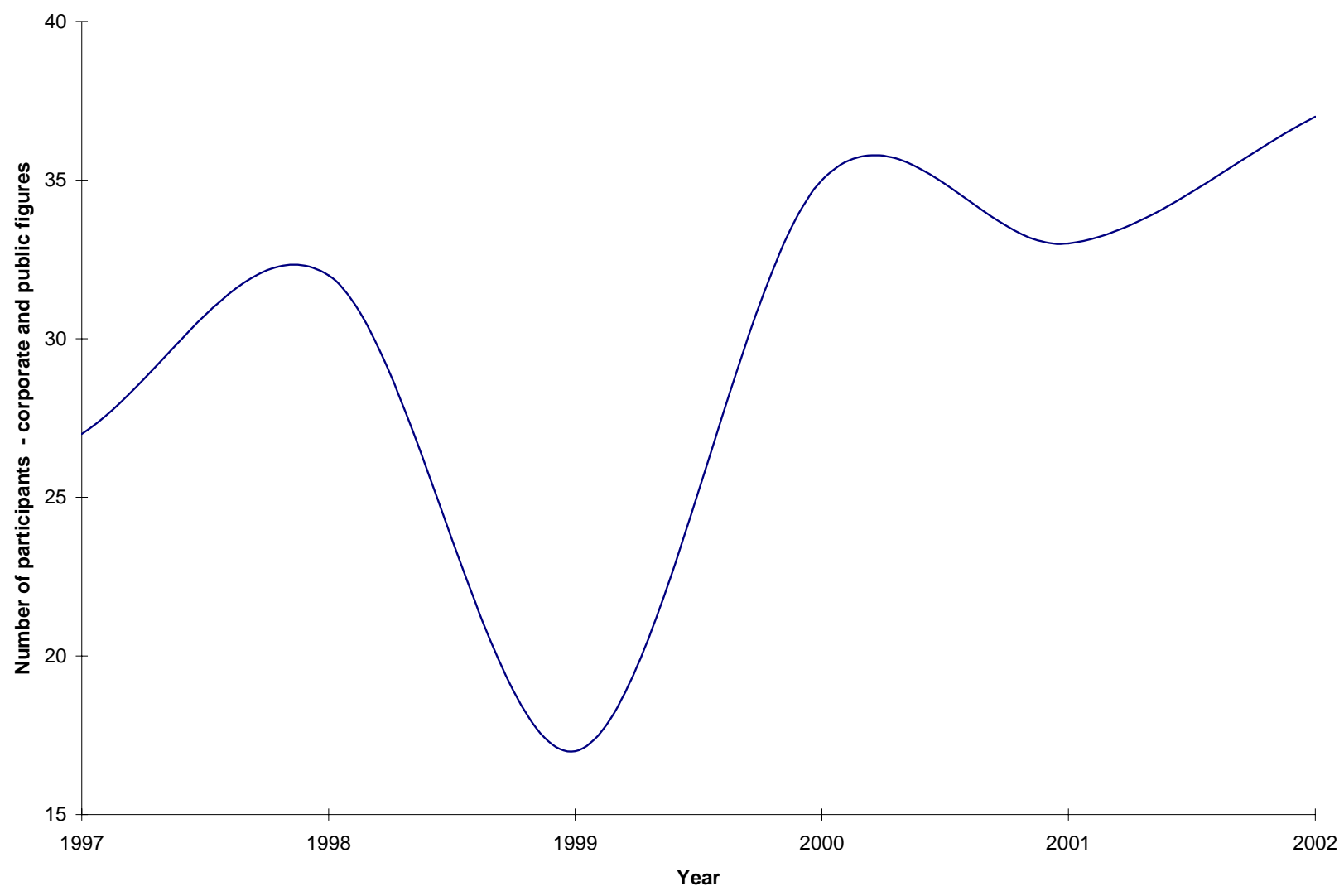

Source: World Economic Forum 


\section{Table 1: How Does Hermitage Generate News?}

\section{Panel A - Generating Initial News}

Below we present slides from a 41 slide Hermitage Powerpoint presentation produced in early 2000 that detailed a series of self-dealing actions by company management involving Stroytransgaz, Itera, Rospan, Zapsibgazprom and other entities. This information was provided to journalists at the Financial Times and Wall Street Journal. We follow the slides with newspaper coverage in the Financial Times and the Wall Street Journal that picks up on this news.

\section{$\underline{\text { Hermitage Slide }}$}

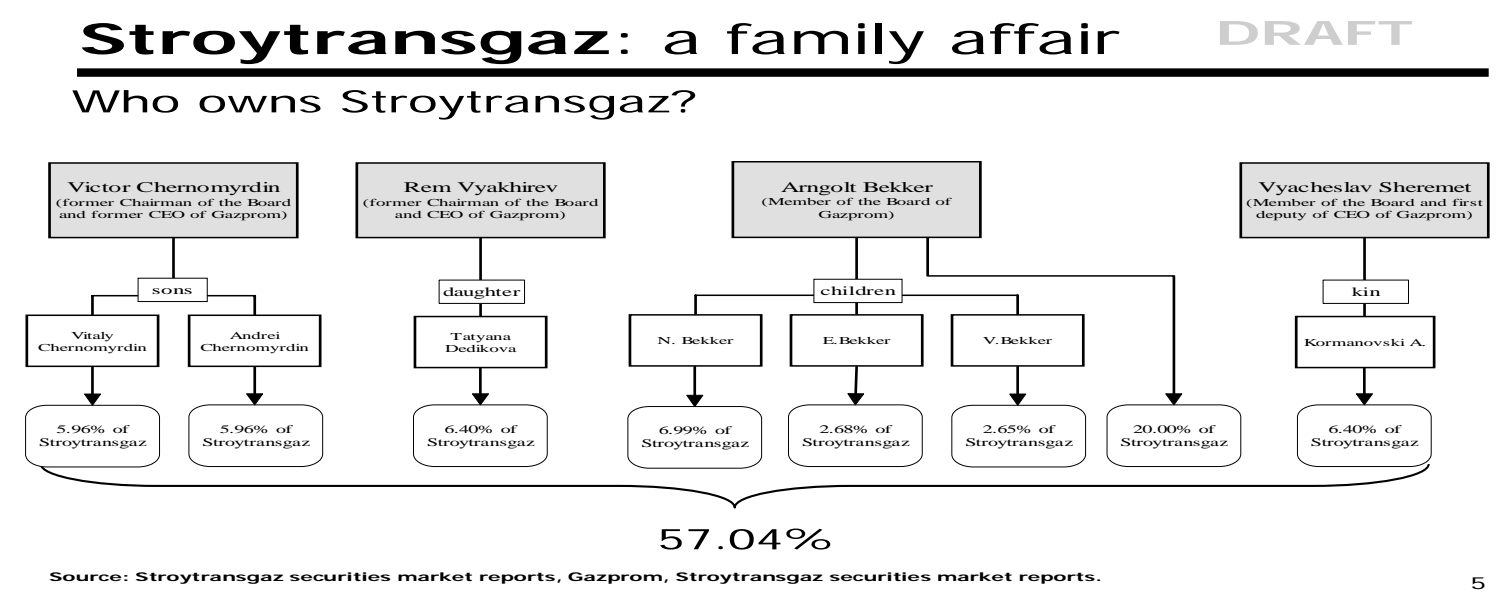

\section{News Reporting Based on Slide}

Financial Times reporting, October 25, 2000

"The FT has learned of one case in which Gazprom has been awarding large contracts to a company which is majority owned by the relatives of Gazprom's past and present management. Stroytransgaz documents from 1999 show that over 50 percent of the pipeline construction company is owned by people close to Gazprom's senior management. These include 6 per cent each by Vitaly and Andrei Chernomyrdin, the sons of the former prime minister, and former head of Gazprom Viktor Chernomyrdin, and a further 6.4 per cent by Tatyana Dedikova, the daughter of Gazprom's chief executive Rem Vyakhirev. A further 20 per cent is held by Arngolt Bekker, Stroytrransgaz's chief executive and a Gazprom director, and three of his relatives hold another 12.3 percent between them...."

Financial Times reporting, October 28, 2000

"The Federal Securities Commission, the market regulator, yesterday confirmed it had asked for an explanation from Gazprom following the publication of an article in Wednesday's Financial Times on relations between the group and Stroytransgaz, a construction company in which present and past senior managers of Gazprom and their relatives are significant shareholders.

Wall Street Journal, October 30, 2000

"Revelations that top Gazprom managers and their family members own a big chunk of Gazprom main pipeline-building contractor, OAO Stroytransgas, also caused concern among investors last week. Gazprom has awarded many lucrative contracts to Stroytransgas...” 

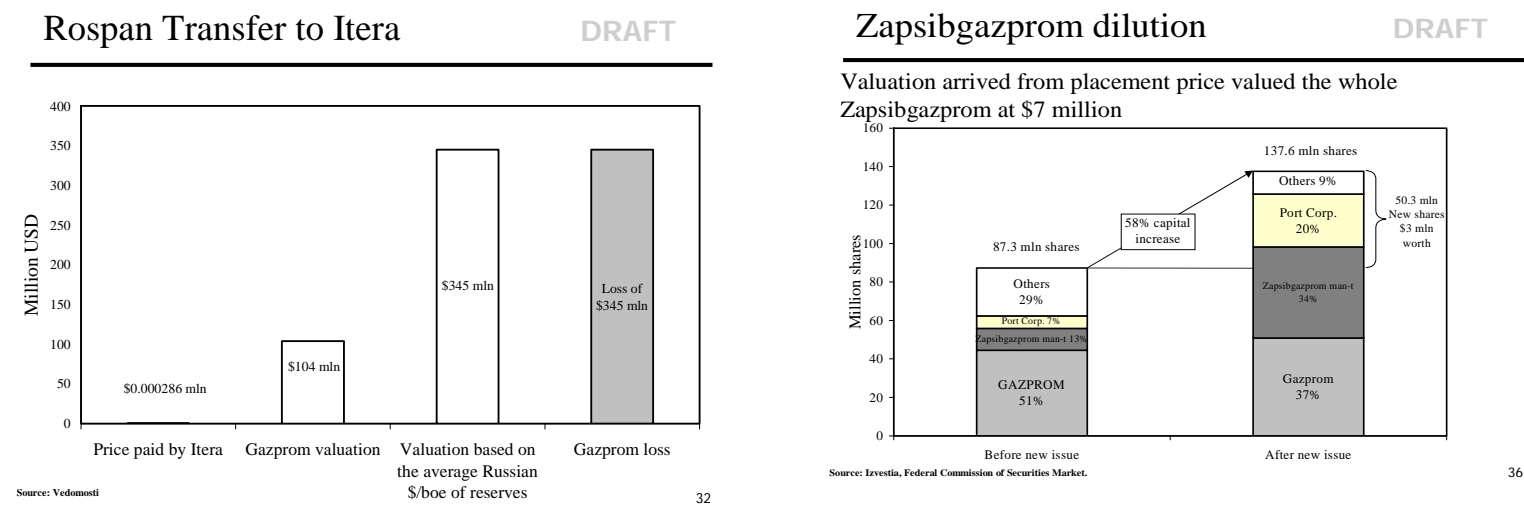

\section{News Reporting Based on Slides}

\section{Wall Street Journal reporting, October 24, 2000}

Investors holding about 20\% of Gazprom complain that Itera has been allowed to gobble up valuable Gazprom assets on the cheap. Take Rospan, a joint venture holding licenses to two fields with reserves of 230 billion cubic meters of natural gas and 80 million metric tons of gas condensate. In 1998, Gazprom decide it couldn't afford to invest in Rospan production and sold its $51 \%$ stake to two shell companies founded and owned by Itera: ZAO STI-Sigma and OOO Lanka-Promkomptekt. Despite Rospan's rich gas reserves, MR. Vyakhirev ordered the stake sold at its nominal price, or par value, of 4,258 rubles -- $\$ 284$ at the time. Gazprom's minority shareholders value the lost gas and gas condensate reserves at \$345 million.

\section{Wall Street Journal reporting, October 30, 2000}

"The board briefly discussed the erosion of Gazprom's stake in Zapsibgazprom, A Siberian firm whose 700 billion cubic meters of gas reserves are valued at about $\$ 600$ million. Gazprom didn't take up its rights in a recent share issue, allowing its stake to fall to $37 \%$ from $51 \%$ according to securities commission documents. Two shell companies of unknown ownership acquired $21 \%$ of the company during the issue. The price of the new stock issued puts the company's market capitalization at just $\$ 12$ million.” 


\section{Panel B - Continued Reporting of Allegations}

This panel plots the number of articles published in the Wall Street Journal and in the Financial Times following the first announcement of a corporate governance violation at Gazprom.

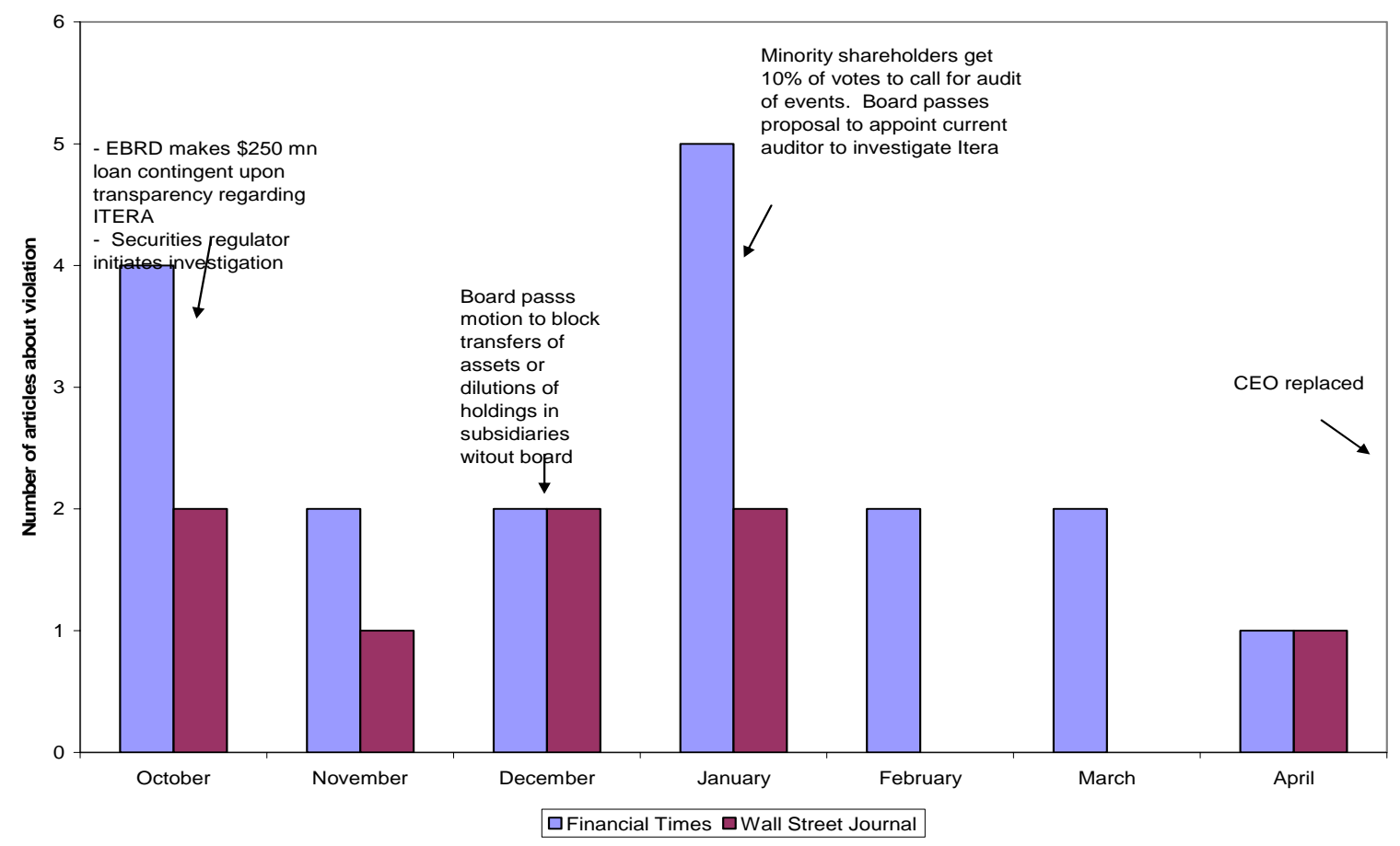




\section{Panel C - Lawsuits Initiated by Hermitage}

This panel reports the list of all the legal suits brought by the Hermitage fund during the sample period and their final outcome.

\begin{tabular}{|c|c|c|c|c|}
\hline Issuer & Description of the Case by Hermitage Capital & $\begin{array}{l}\text { Date of } \\
\text { Initial } \\
\text { Filing }\end{array}$ & $\begin{array}{l}\text { Total } \\
\text { Cases }\end{array}$ & $\begin{array}{l}\text { Cases } \\
\text { Won }\end{array}$ \\
\hline AVISMA & $\begin{array}{l}\text { Isle of Man suit to stop offshore transfer pricing by majority } \\
\text { shareholder (Menatep) }\end{array}$ & Nov-98 & 1 & 1 \\
\hline AVISMA & $\begin{array}{l}\text { Irish suit to stop offshore transfer pricing by majority shareholder } \\
\text { (Menatep) }\end{array}$ & Nov-98 & 1 & 1 \\
\hline AVISMA & $\begin{array}{l}\text { Isle of Man suit to enforce } 1999 \text { Settlement Agreement (see above) } \\
\text { when Menatep/AVISMA attempts to breach }\end{array}$ & Oct-99 & 1 & 1 \\
\hline Central Bank & $\begin{array}{l}\text { Investors in Sberbank filed a lawsuit with the Moscow Arbitration } \\
\text { Court against the Central Bank of the Russian Federation requested } \\
\text { the Court to recognize as invalid the Central Bank's registration of } \\
\text { the new Sberbank share issue. }\end{array}$ & 24-Apr-01 & 4 & 0 \\
\hline Sberbank & $\begin{array}{l}\text { Investors in Sberbank filed a lawsuit with the Moscow Arbitration } \\
\text { Court against Sberbank. Investors requested the Court to recognize } \\
\text { as invalid the decision of Sberbank's supervisory board to approve } \\
\text { the new share issue }\end{array}$ & 24-Apr-01 & 4 & 0 \\
\hline Volzhanka & $\begin{array}{l}\text { Hermitage Capital Management*, the East Europe Development } \\
\text { Fund managed by INVESCO** and U.F.G.I.S. Limited filed lawsuit } \\
\text { against Yurprovider, a company allegedly affiliated with Baring } \\
\text { Vostok, by the minority shareholders. } \\
\text { The lawsuit was followed by lawsuits against personal directors of } \\
\text { Volzhanka affiliated with Baring Vostok which allegedly liable for } \\
\text { interested parties transactions. These lawsuits were some of the first } \\
\text { of their kind in Russia that pursued directors for violating their } \\
\text { fiduciary responsibilities. }\end{array}$ & 05-Oct-01 & 3 & 1 \\
\hline Gazprom & $\begin{array}{l}\text { Lawsuit in Moscow Commercial Court against PwC for false and } \\
\text { misleading forensic audit of Gazprom’s relationship with Itera }\end{array}$ & 15-Apr-02 & 4 & 0 \\
\hline Gazprom & $\begin{array}{l}\text { Lawsuit in Moscow Commercial Court against PwC for false and } \\
\text { misleading } 2000 \text { annual audit of Gazprom }\end{array}$ & 15-Apr-02 & 4 & 0 \\
\hline $\begin{array}{l}\text { Bank Austria / } \\
\text { Creditanstalt }\end{array}$ & $\begin{array}{l}\text { Suit to recover damages from broker taking illicit spreads on equity } \\
\text { trades on the Russian stock market }\end{array}$ & 2002 & 1 & 1 \\
\hline Surgutneftegas & $\begin{array}{l}\text { A group of international investors, including Hermitage Capital } \\
\text { Management, Firebird Management LLC, Prosperity Capital } \\
\text { Management, and the Russian Investor Protection Association } \\
\text { launched a legal action in the Khanty Mansiysk Arbitration Court } \\
\text { against Surgutneftegaz aiming to have the court cancel 62\% of } \\
\text { Surgutneftegaz treasury shares that are being held by the company. }\end{array}$ & 04-Mar-04 & 4 & 0 \\
\hline Sberbank & $\begin{array}{l}\text { Sberbank shareholders requested the Court to support their call for } \\
\text { an extraordinary shareholders meeting made on March } 12 \text { by over } \\
10 \% \text { of Sberbank shareholders. }\end{array}$ & & 4 & 0 \\
\hline Sberbank & Defamation case for the article published by Vedomosti & & 5 & 4 \\
\hline \multirow[t]{3}{*}{ Sberbank } & Defamation Case for the article published by Vremya Novostei & & 4 & 2 \\
\hline & & Total & 40 & 11 \\
\hline & & Domestic & 37 & 8 \\
\hline
\end{tabular}

Source: Hermitage Capital. 


\section{Table 2: Sample of Reported Corporate Governance Violations}

This table describes the 98 alleged governance violations we use in our empirical analysis. We define as potential corporate governance violations those actions that, according to the Russian investment bank Troika Dialog, have a negative impact on the cashflow or voting rights of outside investors. This definition does not necessarily imply that any Russian law was infringed. This sample is based on an initial set of 480 potential governance violations identified using Troika Dialog's “Bulletin on Corporate Governance Actions” from December 1998 to June 2002. In the Appendix we describe the steps involved in refining the initia set of 480 potential infractions to this final sample. The description of the violations in quotes comes from the Troika Dialog's Bulletin. In some cases such a succinct description was not available and we provide our own description based on the reading of the events in the Russian and English language press.

\begin{tabular}{|c|c|c|}
\hline Company & $\begin{array}{l}\text { Date of } \\
\text { reported } \\
\text { violation }\end{array}$ & Reported governance violation (Date of Troika Dialog Corporate Governance Bulletin) \\
\hline Aeroflot & 12-Aug-99 & $\begin{array}{l}\text { "An Aeroflot spokesman has said that the company may increase the number of outstanding shares by 185\%..." (August 12, } \\
\text { 1999) }\end{array}$ \\
\hline Alpha Cement & 8-Dec-99 & $\begin{array}{l}\text { "Shareholders will be asked to increase both the authorized share capital and the number of outstanding shares. It is proposed } \\
\text { to place the new shares with Alpha Cement-related structures via pre-arranged subscription." (January 20, 2000) In the end, } \\
31 \% \text { of shares were placed with designated related party with no disclosed sale price. }\end{array}$ \\
\hline Amurkabel & 15-Mar-00 & $\begin{array}{l}\text { "Amurkabel... was the stage for a violent clash between the current and self-proclaimed directors...in January the company } \\
\text { re-registered as a state unitary enterprise... a shareholder-friendly ruling does not seem imminent." (March 15, 2000) }\end{array}$ \\
\hline Amursvyaz & 28-May-01 & $\begin{array}{l}\text { As part of a plan for consolidation of regional telecom companies, shareholders were asked to approve a swap with Urals } \\
\text { Telecom. The terms of the swap are viewed as detrimental to the interest of minority investors. }\end{array}$ \\
\hline AVISMA & 27-Oct-98 & $\begin{array}{l}\text { "Michael Hunter, president of Dart Management, said that investors like Dart learned from the Austrian bank Creditanstalt, } \\
\text { which organized their } 1997 \text { purchase from Menatep of Avisma shares, of a damaging "distributions arrangement" at Avisma. } \\
\text { Hunter said that upon taking control of Avisma, the investors sued TMC international and Isle of Man-based company } \\
\text { receiving the ill-gotten Avisma revenues, to close down the scheme." (Moscow Times August 24, 1999) }\end{array}$ \\
\hline Avtosvet & 30-Dec-99 & $\begin{array}{l}\text { "On December 30, Avtosvet BoD approved a 50\% share capital increase. In essence, this means a prearranged subscription, } \\
\text { allowing a small group of insiders to increase their control over the company and barring other shareholders from taking up } \\
\text { the new shares. The decision was passed by the directors, one day after a proposal to increase the share capital by } 100 \% \text { had } \\
\text { been voted down at the EGM on December 29." (February 2, 2000) }\end{array}$ \\
\hline AvtoVAZ & 23-Jun-00 & $\begin{array}{l}\text { "AvtoVAZ management has revealed a reorganization program calling to split the company into } 9 \text { business divisions arranged } \\
\text { under a management company...AvtoVAZ may simply end up with R1.2 billion ( } \$ 78 \text { million) in debt, while its assets may be } \\
\text { transferred to these same subsidiaries. If this happens, shareholders will be left with little more than the parent company’s } \\
\text { debt. The likelihood of the company's subsequent bankruptcy and liquidation should not be ruled out." (June 23, 2000) }\end{array}$ \\
\hline AvtoVAZ & 31-May-01 & $\begin{array}{l}\text { "The AvtoVAZ AGM on May } 26 \text {...flouted the law by omitting to mail voting slips to shareholders... Many of those who did } \\
\text { brave the flight to Samara and the } 60 \text { odd mile car ride on May } 26 \text { fared no better. They were thrown out as gatecrashers: the } \\
\text { company had set May } 24 \text { as the deadline for registration." (May 31, 2001) }\end{array}$ \\
\hline
\end{tabular}




\begin{tabular}{|c|c|c|}
\hline Company & $\begin{array}{l}\text { Date of } \\
\text { reported } \\
\text { violation }\end{array}$ & Reported governance violation (Date of Troika Dialog Corporate Governance Bulletin) \\
\hline AvtoVAZ & 26-Apr-02 & $\begin{array}{l}\text { "AvtoVAZ preferred shareholders may soon lose their title to dividends worth } 10 \% \text { of the company's net profits, without } \\
\text { recompense or even a chance to cash out...some shareholders visited the AvtoVAZ HQ, } 1000 \text { km from Moscow, to study the } \\
\text { full AGM materials and reported that the unpopular proposition was indeed on the agenda, lumped together with other, mostly } \\
\text { technical amendments...Why...Possibly because it hopes to have all changes, damaging and innocuous, approved en bloc. } \\
\text { This is clearly against the law..." (May 20, 2002.) }\end{array}$ \\
\hline Babayevsky Confectionery & 22-Feb-00 & $\begin{array}{l}\text { "Babayevsky Confectionery 51\% shareholder, Inkombank, reported plans for a court appeal over the legality of the February } \\
22 \text { EGM, which voted to increase the number of outstanding shares by 33\%. The EGM decision means a } 13 \% \text { decrease in the } \\
\text { bank's stake, reducing it from a majority to a blocking stake, Inkombank said. ... At present, } 27.8 \text { million new shares are to } \\
\text { be issued to three obscure outside investors, SeptStroi, Bimish Investment and Endora." (March 1, 2000) }\end{array}$ \\
\hline Bashkirenergo & 3-Dec-01 & $\begin{array}{l}\text { "On November 23, the Bashkirenergo BoD approved an increase in the company's share capital...The size of the issue is not } \\
\text { known...The law which allows a BoD to approve share issues is on its last legs. From January 1, 2002, share issuance will be } \\
\text { entirely subject to shareholder approval. It seems as if Bashkirenergo is rushing through a dilutive issue before it is too late." } \\
\text { (December, } 3,2001 \text { ) }\end{array}$ \\
\hline Bratsk Pulp & 18-Feb-02 & $\begin{array}{l}\text { "RusAl began to concern itself with the timber industry after it took a blocking minority in Irkustkenergo in mid } \\
\text { 2001...RusAl forcibly replaced Sergei Kovostikov as Bratsk Pulp CEO with loyal Georgi Trifonov and established } \\
\text { operational control...He rescinded an agreement to restructure Bratsk Pulp's R750 (\$25 million) debt to Irkutskenergo, thus } \\
\text { delivering the plant into RusAl's hands." (February 18, 2002) }\end{array}$ \\
\hline Chernogorneft & 17-Jun-99 & $\begin{array}{l}\text { TNK, a holder of Chernogorneft debt, publicly proposes a buyout of Chernogorneft's business. This raises fears that this } \\
\text { auction of assets will not be conducted fairly and will result in a dilution of existing stakes of shareholders in Chernogorneft } \\
\text { including Sidanco shareholders who hold a 73\% stake. }\end{array}$ \\
\hline Elektrosila & 1-Feb-99 & $\begin{array}{l}\text { "A full-blown struggle has broken out for control of Elektrosila, Russia's monopoly manufacturer of power station generators, } \\
\text { with current leadership sparring against new management appointed by the plant's holding company.... German giant } \\
\text { Siemens AG, which holds a } 20 \text { percent stake in the plant, has accused massive holding company EMK of violating } \\
\text { Elektrosila's charter by trying to fire the factory director and replace him with its own man. " (Moscow Times, November 11, } \\
\text { 1999) }\end{array}$ \\
\hline FESCO & 23-Jun-99 & $\begin{array}{l}\text { "Andrew Fox, a British investor in the Far Eastern Shipping Company, or FESCO - Russia's largest shipping concern, with } \\
112 \text { ships and over } \$ 350 \text { million annual turnover - says he was threatened with imprisonment in early June by Yevgeny } \\
\text { Nazdratenko, governor of the Primorye region. Fox says Nazdratenko paired his threat with a demand that seven percent of } \\
\text { the foreign investors' } 42 \text { percent stake in FESCO be turned over in trust to his administration, and that his man be elected } \\
\text { FESCO's chairman of the board. " (Moscow Times, November 2, 1999) }\end{array}$ \\
\hline GAZ & 21-Dec-00 & $\begin{array}{l}\text { News of eventual special GM that gave management increased powers to issue up to } 3 \text { billion new shares, against } 4.5 \text { million } \\
\text { shares outstanding raises concerns about dilution. }\end{array}$ \\
\hline Gazprom & 12-Aug-99 & $\begin{array}{l}\text { "Allegations that Gazprom would transfer revenues away from the gas producer and quietly give ITERA super-profitable } \\
\text { contracts intensified last week in the mass media. Gazprom's top managers denounced allegations of doing illicit business } \\
\text { with ITERA and enriching themselves at the company's cost..." (August 12, 1999) }\end{array}$ \\
\hline Gazprom & 25 -Oct-00 & $\begin{array}{l}\text { Reports of extensive transactions between Gazprom and companies linked to the management, including transactions } \\
\text { involving ITERA, Rospan and Stroitransgaz. }\end{array}$ \\
\hline
\end{tabular}




\begin{tabular}{|c|c|c|}
\hline Company & $\begin{array}{l}\text { Date of } \\
\text { reported } \\
\text { violation }\end{array}$ & Reported governance violation (Date of Troika Dialog Corporate Governance Bulletin) \\
\hline Gazprom & 11-May-01 & $\begin{array}{l}\text { Stakes of significant vehicle for minority shareholding in Gazprom (UFG) are restricted from voting in the upcoming AGM, } \\
\text { making it very unlikely that minority shareholder voice on board will be reelected, thereby strengthening the position of the } \\
\text { incumbent management. }\end{array}$ \\
\hline Irkutskelectrosvyaz & 23-Sep-99 & $\begin{array}{l}\text { "Although the Irkutskelektrosvyaz (ESIR) BoD had recommended skipping dividends for 1998, which the company finished } \\
\text { in the red, ESIR's majority shareholder Svyazinvest (38\%) pushed through a nominal dividend of R0.01 per preferred share, } \\
\text { payable from the company's special reserve. A group of preferred shareholders, led by Energia-Invest, is now seeking to prove } \\
\text { in court that the nominal dividend infringes upon their rights, as preferred shareholders would enjoy voting rights at the next } \\
\text { AGM if no dividend had been paid." (September 23, 1999) }\end{array}$ \\
\hline Izhorsk Works & 23-Jun-00 & $\begin{array}{l}\text { "(Shareholders can) vote twice for one and the same BoD, and have your vote discounted both times. (And as a result not be } \\
\text { able to vote for BoD)" One of principal assets is company Izhorsk Pipe. On July 20, 2000, this company "proposes plans to } \\
\text { float new shares, increasing the share capital by 100-200\%" (June 23, 2000) with allocation already slotted for three parties, } \\
\text { creating the possibility for asset shifting. }\end{array}$ \\
\hline Kaluganefteproduct & 11-Mar-00 & $\begin{array}{l}\text { "TNK subsidiary, Kaluganefteproduct, is poised to increase its share capital hundreds fold from R4835 to R6.6 million. } \\
\text { Although the shares will be offered to the general public and current shareholders will enjoy their pre-emptive right to buy } \\
\text { into the issue, many of the latter are likely to be diluted, as few will want to pay R66 (\$2.3) for an illiquid share." (March 15, } \\
\text { 2000) Extra shares are to be swapped for shares in refinery, so essentially diluting minority shareholders of these oil product } \\
\text { suppliers, so that TNK can control the refinery. }\end{array}$ \\
\hline KAMAZ & 2-Sep-99 & $\begin{array}{l}\text { Company announces plans to pay debt holders through the new issuance of } 600 \text { million company shares with a par value of } 50 \\
\text { rubles, to be distributed among company creditors. While the company argued, "this would allow the company to avoid its } \\
\text { debt increasing due to penalties and fines" minority shareholders which included KKR, with a } 26 \% \text { stake, and EBRD, as } \\
\text { creditor, raised concerns about dilution. }\end{array}$ \\
\hline Kazan Helicopter & 17-Jun-99 & $\begin{array}{l}\text { "Shareholders decided to limit foreign capital participation to } 25 \% \text {. Non-residents are also restricted from heading the } \\
\text { company and board membership. The decision was made to split existing shares 5:1." (June 17, 1999) }\end{array}$ \\
\hline Khantymansiiskokrtelecom & 25-Jul-01 & $\begin{array}{l}\text { As part of a plan for consolidation of regional telecom companies, shareholders are asked to approve a swap with Urals } \\
\text { Telecom. The terms of the swap are viewed as detrimental to the interest of minority investors. }\end{array}$ \\
\hline KomiTEK & 8-Jul-99 & $\begin{array}{l}\text { "Lukoil will issue } 11.5 \text { million convertible preferred shares to KomiTEK shareholders. They will subsequently be converted } \\
\text { into voting common stock." (July 8)"clause } 6.3 \text { of the issue prospectus, registered with the FCSM on August 26, provides that } \\
\text { owners of } 19 \%+\text { of KomiTEK shares can buy extra LUKoil preferreds for just R75 (\$3) per share (clause 6.4). This } \\
\text { translates into LUK oil common share price of just } \$ 0.5 \text { (it was close to } \$ 7.0 \text { on September 23)."(September 23, 1999) }\end{array}$ \\
\hline Krasnoyarsk GES & 23-Jun-99 & $\begin{array}{l}\text { "At their June } 18 \text { AGM, KRSG shareholders approved the BoD decision to float new shares and waived their right of first } \\
\text { refusal...As a result of the issue, the majority shareholder, RAO UES will see its stake reduced from 51\% to 34\%." (June 23, } \\
\text { 1999) }\end{array}$ \\
\hline Krasnoyarsk GES & 8-Jun-00 & $\begin{array}{l}\text { "On June 26, Krasnoyarsk GES is holding an AGM at } 10 \text { am and an EGM at 2pm convened for the sole purpose of replacing } \\
\text { the BoD elected four hours earlier...The company has sent around AGM and EGM notices, but not voting ballots, which it } \\
\text { promised to dispatch later, nor AGM and EGM materials, which shareholders can study at their leisure in Divnogorst, in the } \\
\text { Siberian hinterland. "Make sure to bring your ballot," the EGM notice sternly warns, "You will not get a ballot at the meeting, } \\
\text { if you do not show the one which has been mailed to you." (June 8, 2000) Only no ballots have been mailed of course. }\end{array}$ \\
\hline
\end{tabular}




\begin{tabular}{|c|c|c|}
\hline Company & $\begin{array}{l}\text { Date of } \\
\text { reported } \\
\text { violation }\end{array}$ & Reported governance violation (Date of Troika Dialog Corporate Governance Bulletin) \\
\hline Krasnoyarsk Tire & 20-Jan-00 & $\begin{array}{l}\text { "At their February } 4^{\text {th }} \text { EGM, Krasnoyarsk Tire shareholders will be asked to approve a reorganization program....The potential } \\
\text { threat is that outside shareholders will be left with nothing but debt." (January 20, 2000) }\end{array}$ \\
\hline KrAZ & 7-Jun-99 & $\begin{array}{l}\text { "The AGM voted to approve an additional share issue which will raise } \$ 110 \text { million and double KrAZ’s capital. The state, } \\
\text { which owns } 20 \% \text { of the company, and small shareholders face a } 50 \% \text { dilution, as the new issue will be placed via closed } \\
\text { subscription." (July 15, 1999) }\end{array}$ \\
\hline KrAZ & 3-Feb-00 & $\begin{array}{l}\text { "KrAZ has announced plans to place } 15 \text { million new shares, representing a 53\% increase in the share capital, with } \\
\text { shareholders which control at least } 9.8 \% \text { of existing equity. .... The intricate scheme favors shell companies, registered in the } \\
\text { Seychelles, Virgin Islands and in Cyprus, ostensibly related to Tanako and KrAZ management, which control } 90 \% \text { of KrAZ } \\
\text { equity capital." (February 9, 2000) }\end{array}$ \\
\hline Kuzbassugol & 3-Aug-00 & $\begin{array}{l}\text { "The Kemervo authorities sold the stake in a negotiated deal to an obscure entity, Belon, in January 2000. Koks argued that } \\
\text { the state-owned shares could only be sold at an auction or investment tender..." (August 3, 2000) }\end{array}$ \\
\hline Kuznetsk Ferrous Alloys & 22-May-01 & $\begin{array}{l}\text { "MDM Bank, the new owner of Kuznetsk Ferrous Alloys (KFA), (proposed) to float } 29 \text { million new shares, which would } \\
\text { have increased the number of shares outstanding by } 600 \% \text {. The shares were to be issued to MDM-controlled structures, } \\
\text { diluting the KFA management stake from } 44 \% \text { to } 6 \% \text {." (November 12, 2001) }\end{array}$ \\
\hline Lakokraska & 7-Sep-00 & $\begin{array}{l}\text { "New shares, issued at a 31\% discount to the current market offer price, are designed to dilute preferred shareholders, as the } \\
\text { program gives them no right of first refusal. Lakokraska has never declared, nor paid dividends, which means that preferred } \\
\text { shares, by default, have had voting rights. And it is these votes which seem poised to be diluted by new issue." }\end{array}$ \\
\hline Leningrad Metal Plant & 5-Oct-99 & $\begin{array}{l}\text { "The new share issue aimed to clear outstanding debts was approved by the November } 1 \text { EGM and represents a 114\% } \\
\text { increase in share capital. This program will dilute existing LMZ shareholders by at least 54\%." (November 24. 1999) }\end{array}$ \\
\hline Leningrad Metal Plant & 3-Apr-00 & $\begin{array}{l}\text { Holder of firm debt forces firm into bankruptcy proceedings and, while in proceedings, initiates a new share issue that has the } \\
\text { potential to dilute existing controlling shareholder and other shareholders. }\end{array}$ \\
\hline Lomonosov Porcelain & 1-Jul-99 & $\begin{array}{l}\text { "Leningrad Porcelain Factory: nationalized? State Property declared Ministry leaves 75\% stakeholders in cold." (July 1, } \\
\text { 1999) }\end{array}$ \\
\hline Moscow Refinery & 3-May-00 & $\begin{array}{l}\text { Amendment to charter - instead of paying } 10 \% \text { of net profit to preferred shareholders, it was approved to pay } 10 \% \text { of nominal } \\
\text { value of shares as dividends. }\end{array}$ \\
\hline Mosenergo & 9-Feb-99 & $\begin{array}{l}\text { Firm announces plans to acquire two power plants from major shareholder UES in exchange for the issuance of new shares. } \\
\text { This share issue moves UES from less than 50\% to more than 50\%. Concerns rose about dilution of existing minority } \\
\text { shareholders, value of the acquired plants, and increased scope for transactions that could hurt minority shareholder interests. }\end{array}$ \\
\hline Mosenergo & 17-Jul-01 & $\begin{array}{l}\text { "Mosenergo last week reported plans to call an EGM to replace CEO Alexander Remezov...From a corporate governance } \\
\text { point of view, the outgoing team, headed by Remezov, has been investor-oriented, accessible and efficient. Any change will } \\
\text { therefore likely cause a recession in the company's performance and prompt market players to reassess the stock" (July 17, } \\
\text { 2001) }\end{array}$ \\
\hline NefAZ & 25-Jan-99 & $\begin{array}{l}\text { "Last week's announcement of KamAZ' plan to increase its NefAZ (Neftekamsk truck manufacturer) share capital...no } \\
\text { additional issues has yet been discussed, nor has an EGM to approve the issue so far been called...seems to have little or no } \\
\text { regard for other investors rights." (January 25, 1999) }\end{array}$ \\
\hline
\end{tabular}




\begin{tabular}{|c|c|c|}
\hline Company & $\begin{array}{l}\text { Date of } \\
\text { reported } \\
\text { violation }\end{array}$ & Reported governance violation (Date of Troika Dialog Corporate Governance Bulletin) \\
\hline Nizhevartovskneftegaz & 18-Feb-99 & $\begin{array}{l}\text { "The proposed share swap is causing a rift among shareholders. The swap is part of NNG reorganization and proposed spin- } \\
\text { off of two upstream divisions... it is proposed to transfer } 27 \% \text { of NNGs assets and liabilities to Samotlorneftegaz and } \\
\text { Nizhnevartovsk, } 24 \% \text { and } 3 \% \text { respectively." (February 18, 1999) }\end{array}$ \\
\hline $\begin{array}{l}\text { Nizhnevartovsk Oil and Gas } \\
\text { Production Company }\end{array}$ & 6-Sep-01 & $\begin{array}{l}\text { Nizhnevartovsk Oil and Gas Production Company "will now be offering its shareholders the opportunity of a swap into a } \\
\text { parent company single share, leaving them with no option but to exit their companies.” (September 17, 2001) Viewed as } \\
\text { swap at poor terms. }\end{array}$ \\
\hline Nizhni Tagil Metal Plant & 25-May-00 & $\begin{array}{l}\text { "Nizhni Tagil Smelter has reported plans to ... vote on a revision of the charter ... likely to lead to the spinning off of } \\
\text { company assets, leaving shareholders exposed to the risk of share devaluation.” (May 25, 2000) }\end{array}$ \\
\hline Norilsk Nickel & 15-Jun-00 & $\begin{array}{l}\text { Export trading arm Norimet is bought with shares of production subsidiary, Norilsk Mining. Shareholder raise concerns on } \\
\text { terms for swap, ("valued 37.9\% of NMC at a ludicrously small R83.9 million ( } \$ 2.9 \text { million at the exchange rate prevalent in } \\
\text { April)") (January 25, 2001) particularly as trading arm linked with controlling shareholder in Norilsk Nickel, and while } \\
\text { transfer may have met all legal rules, it was not put to shareholders for approval. }\end{array}$ \\
\hline Norilsk Nickel & 18-Sep-00 & $\begin{array}{l}\text { Announces plans to wind up holding company, Norilsk Nickel, by swapping shares with production subsidiary, Norilsk } \\
\text { Mining. "We are negative about the effect of the NMC-Norimet-Norilsk Nickel consolidation, which would dilute the } \\
\text { publicly owned stake in the NMC, and particularly about the way in which insiders have steamrollered the restructuring } \\
\text { through, without consulting outside shareholders." (November 23, 2000) }\end{array}$ \\
\hline North Western Telecom & 18-Feb-02 & $\begin{array}{l}\text { "At their Feb } 15 \text { meeting, NWT directors voted to sell off the company's } 43 \% \text { stake in Delta Telecom (24\% of the votes) to an } \\
\text { obscure offshore company, TELCO Overseas, for just } \$ 2.9 \text { million." "The latest decision by North Western Telecom to sell } \\
\text { off assets below their market value raises a question mark over the management's commitment to increasing the shareholder } \\
\text { value and turns a spotlight on the inadequate accountability of the board... The recent deal cannot be anything but detrimental } \\
\text { to NWT' outside minority." (March } 4,2002)\end{array}$ \\
\hline NOSTA & 23-Jun-99 & $\begin{array}{l}\text { "Nost Metallhandels owns } 63 \% \text { of Nosta's share capital, but as yet has no say in company's operations." (June 23, 1999) "New } \\
\text { issue being planned by the company would increase its charter capital by } 50 \% \text {." (July 8, 1999) }\end{array}$ \\
\hline NOSTA & 7-Oct-99 & $\begin{array}{l}\text { "Avtobank has given NOSTA some } \$ 80-120 \text { million in loans that were reportedly used to settle wage and tax arrears. The } \\
\text { regional government is anxious because it says that the company cannot service so much debt and threatens that the new } \\
\text { creditors may eventually seize the assets." (October } 7,1999)\end{array}$ \\
\hline Novolipetsk Metal & 27-Jan-99 & $\begin{array}{l}\text { Management attempted hostile takeover through } \$ 100 \text { million share issue in closed subscription to large shareholders. "CCM, } \\
\text { which manages } 29 \% \text { of Novolipetsk share capital, has said that Novolipetsk management is using Russia’s crises as an excuse } \\
\text { to "hijack the business" and disenfranchise minority shareholders." (February 10, 1999). }\end{array}$ \\
\hline Novolipetsk Metal & 13-Jul-00 & $\begin{array}{l}\text { Management refused large shareholders to access financial information pertaining to the sale of its business unit, the Stinol } \\
\text { factory. }\end{array}$ \\
\hline Novorossiisk Shipping & 19-Apr-01 & $\begin{array}{l}\text { "Shareholders will be asked to vote on what amounts to a } 200 \text { fold reduction in the size of minimum preferred dividends..." } \\
\text { Ministry of transport officials in Moscow said that the government, which owns } 35 \% \text { of Novoship's shares, recently } \\
\text { discovered the sale of } 75 \% \text { minus one share of Novoship-Invest. The deal, the sources said, took place about a month ago. } \\
\text { Novoship-Invest is an affiliate of Novoship and holder of } 8 \% \text { of the parent company's shares." (Loyds list, April 20, 2001) }\end{array}$ \\
\hline
\end{tabular}




\begin{tabular}{|c|c|c|}
\hline Company & $\begin{array}{l}\text { Date of } \\
\text { reported } \\
\text { violation }\end{array}$ & Reported governance violation (Date of Troika Dialog Corporate Governance Bulletin) \\
\hline Novosibirskenergo & 19-Apr-01 & $\begin{array}{l}\text { "A court on April } 17 \text { issued an injunction against the voting of two blocks of shares in the company (some } 20 \% \text { of the votes)" } \\
\text { (April 19, 2001) }\end{array}$ \\
\hline Noyabrskneftegaz & 1-Dec-98 & $\begin{array}{l}\text { Sibneft consolidated daughter companies (Noyabrskneftegaz and Noyabrsknetegasgeophysika) using the transfer to a single } \\
\text { share scheme at what are viewed as unfair swap ratios. }\end{array}$ \\
\hline Noyabrskneftegaz & 27-Dec-00 & Sibneft asks subsidiary Noyabrskneftegaz for further consolidation through reverse share split. \\
\hline Omskenergo & 5-Nov-01 & $\begin{array}{l}\text { "Omskenergo proposes changes increasing exposure to restructuring risks...it has also been proposed to authorize the } \\
\text { executive board to approve any deal involving company assets worth } 25 \% \text { of the company's book value...they reduce the } \\
\text { accountability of the management and increase the exposure of outside shareholders to asset stripping." (November 5, 2001) }\end{array}$ \\
\hline Orenburgneft & 28-Apr-00 & $\begin{array}{l}\text { "YUKOS, which owns at least } 16 \% \text { (or 31\%, according to some accounts) of this Onaco subsidiary, claims that the company } \\
\text { did not send it an AGM notice (and called) ...for a revision of the authorized capital..." (May 25, 2000) }\end{array}$ \\
\hline Petmol Dairy & 1-Feb-00 & $\begin{array}{l}\text { "Two Petmol shareholders ... sold a } 47 \% \text { stake in Roska Dairy ... to three outside individual investors without allowing its } \\
\text { fellow shareholders to exercise their right of first refusal. Even worse, it flouted the UPD articles of incorporation, signed in } \\
\text { November 1999, which stipulated that equity contributions could not be disposed of for at least five years." (March 15, 2000) }\end{array}$ \\
\hline Purneftegaz & 12-Apr-00 & $\begin{array}{l}\text { "It is proposed to approve the issue of } 160 \text { billion new shares, } 75 \% \text { common and } 25 \% \text { preferred, which implies a } 1,436 \text { fold } \\
\text { increase in the number of share outstanding...it does leave shareholders exposed to future dilution, as, according the } \\
\text { purneftegaz charter, the power to approve new share issues (under } 75 \% \text { of the company's asset values) rests with the BoD. " } \\
\text { (April 12, 2000) }\end{array}$ \\
\hline Purneftegaz & 6-Jul-01 & $\begin{array}{l}\text { "(Purneftegaz) EGM approved the sale to Rosneft of a total of } 18 \text { million tons of crude oil at an average price of } \$ 5 / \mathrm{bbl} \\
\text { (\$36.5/ton) which barely covers Purneftegaz' production costs. ...Purneftegaz shareholders also agreed to transfer } \$ 273 \\
\text { million worth of equipment to the holding company, to repay R } 8.2 \text { billion ( } \$ 273 \text { million) in debt...Shareholders were never } \\
\text { told what the equipment being transferred was. Yes, and is it really worth only } \$ 273 \text { million?" (August 3, 2001) }\end{array}$ \\
\hline Purneftegaz & 18-Feb-02 & $\begin{array}{l}\text { "Rosneft has been a mediocre parent to Purneftegaz: last year it snatched away its value-creating assets and is now poised to } \\
\text { dilute dissenting shareholders by forcing them to buy stock of empty subsidiaries at a premium to their net value." (March } 4 \text {, } \\
\text { 2002) }\end{array}$ \\
\hline RAO UES & 5-Apr-00 & $\begin{array}{l}\text { UES proposes restructuring plan for industry that minority shareholders contend will open up ample opportunities for self- } \\
\text { dealing by company insiders. }\end{array}$ \\
\hline Rospan & 10 -Aug-00 & $\begin{array}{l}\text { "Rospan was under external management, with Itera comfortably controlling } 51 \% \text { of the equity and } 80 \% \text { of its own debt, } \\
\text { when, just four months before external management was due to expire, two related gas traders, Nafta-Energia and Yamalstroi, } \\
\text { were added to the company's creditors' list. Between them, they had suddenly been discovered to control some } 60 \% \text { of its } \\
\text { debt." (August } 10,2000 \text { ) }\end{array}$ \\
\hline Rosshelf & 18-Feb-02 & $\begin{array}{l}\text { "Rosshelf, which is } 55 \% \text { owned by Gazprom, has reported plans to issue } 100 \text { million new shares to clear the outstanding } \$ 150 \\
\text { million in debt to the gas giant...little more than a predatory asset hunt, disguised as asset restitution." (February 18, 2002) }\end{array}$ \\
\hline Rostselmash & 4-Dec-98 & $\begin{array}{l}\text { "Kontrast, which is a RSM minority shareholder, filed a lawsuit against RSM, appealing to reverse the deal that siphoned off } \\
\text { all of the parent company's viable assets, leaving it with massive liabilities and no assets." (December 4, 1998) }\end{array}$ \\
\hline
\end{tabular}




\begin{tabular}{|c|c|c|}
\hline Company & $\begin{array}{l}\text { Date of } \\
\text { reported } \\
\text { violation }\end{array}$ & Reported governance violation (Date of Troika Dialog Corporate Governance Bulletin) \\
\hline Sakhalinmorneftegaz & 14-Mar-00 & $\begin{array}{l}\text { "Rosneft subsidiary Sakhalinmorneftegaz will hold an AGM on April } 26 \text {. Shareholders will ... be asked to waive their } \\
\text { statutory right to have their stakes redeemed by a shareholder which has accumulated more than } 30 \% \text { of the company's } \\
\text { equity...The mere fact of waiving their major right, combined with the general lack of transparency, should be enough to put } \\
\text { small shareholders, which control at least } 10 \% \text { of the company, on their guard." (April 12, 2000) }\end{array}$ \\
\hline Sakhaneftegaz & $16-$ Feb-00 & $\begin{array}{l}\text { "It is proposed to place } 3 \text { million new shares with the Sakha government, which increases its control up to } 59 \% \text {, to reimburse } \\
\text { it for R26.6 million }(\$ 930,000) \text { in capital investment. The implied market capitalization is therefore only } \$ 3.99 \text { million, with } \\
\text { the shares priced at a } 30 \% \text { discount to their current market value }(\$ 1) \ldots \text { Shareholders will vote by correspondence, which } \\
\text { increases the scope for potential corporate governance violation.” (March } 15,2000)\end{array}$ \\
\hline Samaraneftegaz & 24-Feb-99 & $\begin{array}{l}\text { "Samaraneftegaz has announced plans to issue 67,490.280 additional common shares. The issue represents a } 238 \% \text { increase in } \\
\text { SNGs charter capital (Threat: capital dilution). The company proposed to place the issue via closed } \\
\text { subscription...Shareholders will be asked to approve all Samaraneftegas BoD decisions made through } 1997 \text { and } 1998 \ldots \\
\text { Furthermore, Samaraneftegas directors believe that it will do no harm to get carte-blanches for future restructuring deals and } \\
\text { ask shareholders to authorize any spin-offs and asset stripping that the BoD may, at any time, consider appropriate. They will } \\
\text { therefore ask shareholder to okay future deals "in bulk." (February 24, 1999) "On March 23, a bailiff opened the } \\
\text { Samaraneftegaz EGM by reading out a court ruling barring four companies ... from voting their shares. By } \\
\text { "excommunicating" its four major critics Yukos secure 95.7\% of votes. (March 24, 1999) }\end{array}$ \\
\hline Samotlorneftegaz & 18-Feb-99 & $\begin{array}{l}\text { "The proposed share swap is causing a rift among shareholders. The swap is part of NNG reorganization, and proposed the } \\
\text { spin-off of two upstream divisions... it is proposed to transfer } 27 \% \text { of NNGs assets and liabilities to Samotlorneftegaz and } \\
\text { Nizhnevartovsk } 24 \% \text { and } 3 \% \text { respectively." (February 18, 1999) }\end{array}$ \\
\hline Samotlorneftegaz & 6-Sep-01 & $\begin{array}{l}\text { "Will now be offering its shareholders the opportunity of a swap into a parent company single share, leaving them with no } \\
\text { option but to exit their companies." (September 17, 2001) Viewed as swap at poor terms. }\end{array}$ \\
\hline Samson & 24-Aug-00 & $\begin{array}{l}\text { "Over the last } 12 \text { months, the Moscow Industrial Bank has accumulated } 20 \% \text { of Samson outstanding debts, carried out a } \\
\text { major restructuring at the company, and is now set to replace the top management. As part of a restructuring program Samson } \\
\text { has hived off some } 20 \% \text { of each of its seven subsidiaries." (August } 24,2000 \text { ) assets, moved away form the company in } 17 \\
\text { consequent deals in late } 1999 \text {-early } 2000 \text {, were undervalued by "at least R320-550 million". }\end{array}$ \\
\hline Sberbank & 27-Dec-00 & $\begin{array}{l}\text { "On December 27, Sberbank BoD reportedly discussed } 1999 \text { financial results and a new share issue program...if the bank } \\
\text { decides to fill in the authorized cap, by issuing a further } 4.99 \text { million share, then this will lead to a } 36 \% \text { increase in the voting } \\
\text { shares..." we assess the exposure to potential dilution of outside shareholders as "vulnerable to high." (Jan 25, 2000) }\end{array}$ \\
\hline Sibneftegazpererabotka & 22-Jun-99 & $\begin{array}{l}\text { "This summer SIBUR staged several shareholders meetings at Sibneftegazperabotka. The meeting pushed through the } \\
\text { reorganization of the company, whereby its crown jewels (ten gas refineries) were transferred to SIBUR-Tyumen and the } \\
\text { parent company was left with debt and little else ... SbNG offered to pay dissenting shareholders R0.002 per share, which was } \\
\text { the value arrived at by an outside appraiser, the obscure Audit-master, hired by SIBUR (it was not the auditor appointed by } \\
\text { the AGM)." }\end{array}$ \\
\hline SibUr-Neftekhim & 3-Aug-00 & $\begin{array}{l}\text { "(Large shareholder) is suing the Neftekhim CEO for signing off his company’s \$18.8 million (R525 mln) stake. This } 48 \% \\
\text { stake was allegedly sold to a third party without consulting the parent company and controlling shareholder” }\end{array}$ \\
\hline
\end{tabular}




\begin{tabular}{|c|c|c|}
\hline Company & $\begin{array}{l}\text { Date of } \\
\text { reported } \\
\text { violation }\end{array}$ & Reported governance violation (Date of Troika Dialog Corporate Governance Bulletin) \\
\hline Sidanco & 7-Apr-99 & $\begin{array}{l}\text { "Liquidation proceedings were initiated by Beta-Eco, one of Sidanco's creditors, claiming that it was owed R 0.5 } \\
\text { million...pending the Court's decision, a Beta-Eco representative was appointed to run the company as an outside manager." } \\
\text { (April 7, 1999) }\end{array}$ \\
\hline Slavneft-Megionneftegaz & 6-Jul-00 & $\begin{array}{l}\text { "TNK, a } 12.8 \% \text { shareholder in Slavneft, got no seat on the new board...Ahead of the Slavneft AGM, the adamant Slavneft } \\
\text { won a court indictment, barring TNK from voting on its stake." (July 6, 2000) }\end{array}$ \\
\hline Stepan Razin Brewery & 8-Dec-99 & $\begin{array}{l}\text { "Stepan Razin to dilute shareholders... The decision to increase the share capital by } 83 \% \text { was approved by shareholders...It is } \\
\text { proposed to distribute new shares equally between three private companies, via closed subscription....the shares will be paid } \\
\text { for by veksels, issued by those companies." (December } 8,1999 \text { ) }\end{array}$ \\
\hline SUAL & 11-Nov-01 & $\begin{array}{l}\text { "The number of authorized shares was increased by } 260 \% \text { on November } 11 \text {, raising the specter of dilution, as will any such } \\
\text { increase whose purpose is kept secret. What makes it particularly worrying in SUAL's case is that insiders completely } \\
\text { dominate the board." Nov } 16 \text { "holding company sold } 1.5 \text { billion new shares at an } 80 \% \text { discount to the market to an obscure } \\
\text { offshore company, Dirraffe. That issue increased SUAL's share capital by } 260 \% \text { but earned the company a mere } \$ 50 \\
\text { million." (July 8, 2002) }\end{array}$ \\
\hline Surgutneftegaz & 24-Jan-00 & $\begin{array}{l}\text { "In early January Surgutneftegaz crafted a consolidation program, which, if approved by the EGM called for February } 10 \text {, } \\
\text { would increase management's holding of voting share to } 40 \% \text { and give it control over "treasury stock" (33\%). Outside } \\
\text { shareholders would see their combined stake decline from } 31 \% \text { to less than } 25 \% \text {, less than a blocking minority...There are } \\
\text { several reasons for concern. (1) The swap rates remain unknown...(2) ...there may be no way to verify interested-party } \\
\text { transaction requirements...(3) The company has yet to confirm that preferred shareholders will be allowed to vote...(4)... the } \\
\text { shares which the company currently owns in the subsidiary, rather than being cancelled...management will have the proxy to } \\
\text { vote them." (February } 2,2000)\end{array}$ \\
\hline TNK-Nyagan & 6-Sep-01 & TNK initiated reverse share split that has the potential to squeeze out minority investors. \\
\hline Tomsk Refinery & 24-Jun-99 & $\begin{array}{l}\text { "The decision of a } 25 \% \text { dilution was accompanied by a generous proposal from the BoD to all existing shareholders to take up } \\
\text { the new shares at R848 (\$35) each and a dubious offer to buy shares from dissenting shareholders at R21 (\$0.86) per share." } \\
\text { (June } 24,1999)\end{array}$ \\
\hline Tomskneft VNK & 24-Feb-99 & $\begin{array}{l}\text { "Tomskneft... will hold an EGM... The agenda of the meeting includes the approval of a } 41 \% \text { increase in of Tomskneft share } \\
\text { capital, and the authorization of } 82 \text { million new shares issued to five Yukos-affiliated offshore companies... It is also } \\
\text { proposed that all structural changes made by the BoD from } 1997 \text { until the EGM be approved (i.e. the creation of } 32 \text { daughter } \\
\text { companies and the transfer of } \$ 159 \text { million in Tomskneft assets to subsidiaries). Shareholders will be asked to vote on } \\
\text { amendments to the charter... (that) would give the BoD unbridled powers, leaving shareholders defenseless. (March 10, 1999) } \\
\text { "When shareholders arrived that morning to the address announced in the EGM notice, they discovered a note, on a sheet of } \\
\text { paper stuck to the wall, saying that the meeting would take place at a different location, the now well-known town of Mosalsk } \\
\text { (a 2-3 hour drive from Moscow). By doing so YUKOS, which had so far been selective in barring shareholders from general } \\
\text { meetings (keep the 'undesirables' out and let 'good old boys' in), has displayed unusual impartiality by leaving all outside } \\
\text { shareholders out of the action..." (June 17, 1999) }\end{array}$ \\
\hline
\end{tabular}




\begin{tabular}{|c|c|c|}
\hline Company & $\begin{array}{l}\text { Date of } \\
\text { reported } \\
\text { violation }\end{array}$ & Reported governance violation (Date of Troika Dialog Corporate Governance Bulletin) \\
\hline Transneft & 8-Jul-99 & $\begin{array}{l}\text { "At the Transneft AGM, the government, which owns 100\% of voting stock, voted to slash preferred dividends to R0.5 } \\
\text { (compared with R56.6 in 1997). Transneft still owes about R133.6 million ( } \$ 5.5 \text { million) in } 1997 \text { preferred dividends. } \\
\text { Preferred shareholders have not received any dividends, but because dividends were announced, they could not vote at the } \\
\text { AGM. The state has pushed through an amendment, whereby the company, instead of } 10 \% \text { of net profit, will pay fixed } \\
\text { preferred dividends of only R0.5." (July 8, 1999) }\end{array}$ \\
\hline Tulanefteproduct & 8-Dec-99 & $\begin{array}{l}\text { "Tulanefteproduct, a Transnefteproduct subsidiary, has announced plans to increase its share capital by 59\% via additional } \\
\text { share issue. It is proposed to place the new shares with insiders via closed subscription. The proposal will be discussed at the } \\
\text { EGM, scheduled for January 8." (December 8, 1999) }\end{array}$ \\
\hline Tyumenneftegaz & 6-Sep-01 & $\begin{array}{l}\text { "Will now be offering its shareholders the opportunity of a swap into a parent company single share, leaving them with no } \\
\text { option but to exit their companies." (September 17, 2001) Viewed as swap at poor terms. }\end{array}$ \\
\hline Ugraneft & 3-Aug-01 & $\begin{array}{l}\text { "Ugraneft is controlled by Sibir Energy, which has a majority on its board. However, TNK, which own only } 2.4 \% \text { of } \\
\text { Ugraneft through Chernorgorneft, staged a general meeting for Ugraneft shareholders on June 28, which elected rival } \\
\text { executive and supervisory bodies." (August } 3,2001 \text { ) }\end{array}$ \\
\hline Uralkaly & 25-May-00 & $\begin{array}{l}\text { "Uralkaly shareholder received their voting ballots on May 22, two days prior to the cutoff date. At the AGM on May 26, } \\
\text { shareholders are scheduled to revise the charter...These changes... appear controversial and hardly in the best interest of } \\
\text { outside shareholders." (May 25, 2000) }\end{array}$ \\
\hline Ust-Ilimsk Timber & 27-Aug-01 & $\begin{array}{l}\text { A prominent investor forces production subsidiary (Ust-Ilimsk Timber) into bankruptcy and in the process allegedly transfers } \\
\text { assets to himself. }\end{array}$ \\
\hline Vannady & 4-Nov-00 & $\begin{array}{l}\text { "On October 24, the creditor’s board approved a decision to issue new shares, made by the external manager, Oleg Kozyrev. } \\
\text { No further details were released...this latest blow is aimed against the shareholders of Vannady." (November 4, 2000) }\end{array}$ \\
\hline Viksunsk Pipe & 26-Jan-99 & Proposed share redemption at a price 4 times lower than the price of new shares. \\
\hline Vladimir Tractor & 1-Jun-00 & $\begin{array}{l}\text { "At their AGM on June } 3 \text {, Vladimir Tractor shareholders will vote on changes to the company charter. The board would also } \\
\text { be authorized to approve, without shareholders consent, interested and related party transactions if the party involved is an } \\
\text { executive director, a BoD member or an entity which owns at least } 20 \% \text { of the company. Yet another proposal would give the } \\
\text { BoD discretion over transaction involving } 25-50 \% \text { of the company's assets..." (June } 1,2000 \text { ) }\end{array}$ \\
\hline Volgotanker & 10-Mar-99 & $\begin{array}{l}\text { "Filed suit against Volgotanker management, hoping to force a reversion of its earlier decision to split the largest Russian } \\
\text { river shipping company into three separate companies...the parent company fleet to be transferred to its daughters. By } \\
\text { spinning off its profitable assets, the parent company (of which the regional government owns 20\%) will be left with bad } \\
\text { debts." (March 10, 1999) }\end{array}$ \\
\hline VSMPO & 28-Nov-98 & $\begin{array}{l}\text { "A small group of investors...claim that they were barred from exercising their right of first purchase, when VSMPO placed } \\
\text { two } 19.9 \% \text { stakes with affiliated companies...(which led to) the election of a VSMPO-dominated BoD at the May AGM. The } \\
\text { placement price was R6.5 per share, } 84 \text { times below market." }\end{array}$ \\
\hline VSMPO & 01-Sept-99 & Controlling shareholder sues minority shareholders (who previously sued management) in US court. \\
\hline Yakutskenergo & 19-Oct-00 & $\begin{array}{l}\text { "Alrosa, a diamond prodsucer based in the far north of Russia, has reported acquiring a majority stake in Viloyskos, a power } \\
\text { plant currently under construction ... (from) Yakutskenergo. The price of the deal has not been disclosed ... Yakutskenergo } \\
\text { had alone invested } \$ 606 \text { million in its constructions.” (October, 19, 2000) }\end{array}$ \\
\hline
\end{tabular}




\begin{tabular}{|l|l|l|}
\hline \multicolumn{1}{|c|}{ Company } & \multicolumn{1}{|c|}{$\begin{array}{c}\text { Date of } \\
\text { reported } \\
\text { violation }\end{array}$} & \multicolumn{1}{|c|}{ Reported governance violation (Date of Troika Dialog Corporate Governance Bulletin) } \\
\hline YANOS & 16-Jun-00 & $\begin{array}{l}\text { "(Slavneft) immediately pushed through a motion to reduce the number of Yaroslavneftegorgsintez directorships from ten to } \\
\text { seven. These they easily filled with their own representatives, banishing TNK, which had had the other seats, from the } \\
\text { board." (June 16, 2000) }\end{array}$ \\
\hline Yuganskneftegaz & $\begin{array}{l}\text { "Approval of oil sales by YFGA to Yukos-controlled entities at R250 per ton for the next three years. Retroactive approval of } \\
\text { the establishment of 59 daughter companies and prospective approval of 60 more subsidiaries to be created over the next three } \\
\text { years. Transfer of \$1 billion in assets from the parent company to 119 subsidiaries. Shareholders that do not attend the } \\
\text { meeting or vote against the proposals, will be bought out for as little as R7.5 per share (33 cents), which values } \\
\text { Yuganskneftegaz's oil reserves at just \$0.0003 per barrel. (March 24, 1999) }\end{array}$ \\
\hline YUKOS & $\begin{array}{l}\text { "YUKOS NK shareholders approve suspicious major transaction and waive "tag-along right." At their June 29 AGM, } \\
\text { YUKOS NK shareholders effectively voted to sell a major stake to an offshore company, Hulley Enterprises Ltd. On June 8, } \\
\text { the BoD approved a new issue, which represents a 25\% increase of the charter capital." (July 8, 1999) }\end{array}$ \\
\hline
\end{tabular}


Table 3 - Variable Definitions and Sources

\begin{tabular}{|c|c|c|}
\hline Variable & Definition & Source \\
\hline Type of governance violation & $\begin{array}{l}\text { Based on a reading of the event reported in Troika Dialog's } \\
\text { "Bulletin on Corporate Governance Actions” and news stories } \\
\text { about the event in Russian and English news sources, we code } 7 \\
\text { mutually exclusive categories of alleged violation, which include } \\
\text { disenfranchisement and six types of dilution (Share Issuance, } \\
\text { Share Swap, Reorganization, Bankruptcy, Asset Stripping and } \\
\text { Other). }\end{array}$ & $\begin{array}{l}\text { Troika Dialog’s “Bulletin on Corporate Governance } \\
\text { Actions” + Russian and English news sources in } \\
\text { Factiva. }\end{array}$ \\
\hline Maximum loss due to dilution & $\begin{array}{l}\text { The maximum potential loss variable assumes the proposed } \\
\text { action went through and the worst fears were realized for } \\
\text { minority shareholders. }\end{array}$ & $\begin{array}{l}\text { Federal Comission on Security Market Disclosure } \\
\text { project, and Troika Dialog “Bulletin on Corporate } \\
\text { Governance Actions.” }\end{array}$ \\
\hline $\begin{array}{l}\text { Maximum loss due to } \\
\text { disenfranchisement }\end{array}$ & $\begin{array}{l}\text { When the action is a disenfranchisement, we use a three point } \\
\text { scale from lowest (1) to highest (3) severity of the potential loss. }\end{array}$ & Same as above \\
\hline $\begin{array}{l}\text { Outcome of potential governance } \\
\text { violation }\end{array}$ & $\begin{array}{l}\text { For each alleged violation we code the outcome equal to } 0 \text { if it } \\
\text { was not redressed at all, } 1 \text { if partially redressed, and } 2 \text { if } \\
\text { substantially redressed. }\end{array}$ & $\begin{array}{l}\text { Troika Dialog’s “Bulletin on Corporate Governance } \\
\text { Actions” + Russian and English news sources in } \\
\text { Factiva. }\end{array}$ \\
\hline $\begin{array}{l}\text { News coverage of alleged } \\
\text { governance violation }\end{array}$ & $\begin{array}{l}\text { The number of articles in English newspapers (WSJ and FT) and } \\
\text { in Russian papers (Kommersant, Izvestia and Vedemosti) is based } \\
\text { on a count of the number of articles mentioning a company in the } \\
\text { specified newspaper during the period from t-1 month to t+2 } \\
\text { months after the date of the alleged violation. We read the } \\
\text { complete text of all articles with the company name, and retained } \\
\text { only those articles that made a reference to the alleged violation. }\end{array}$ & Factiva, ISI Emerging Markets \\
\hline Newsworthiness & $\begin{array}{l}\text { Number of articles mentioning a company in the in English } \\
\text { newspapers (WSJ and FT) in a period prior to the violation and } \\
\text { before the Russian currency crises, which we define as January- } \\
\text { July } 1998 .\end{array}$ & Factiva, ISI Emerging Markets. \\
\hline Foreign ownership stake & Proportion of stock held by foreign investors. & $\begin{array}{l}\text { Official recording of the identities of all shareholders } \\
\text { with more than } 5 \text { percent stake, collected by Federal } \\
\text { Commission on Security Market Disclosure project } \\
\text { complemented with accounts in the business press } \\
\text { (Russian and English) and in Troika Dialog "Bulletin } \\
\text { on Corporate Governance Actions,” }\end{array}$ \\
\hline EBRD dummy & Dummy variable equal to 1 if the EBRD has provided loan & EBRD Investments: 1991-2004, which lists loans by \\
\hline
\end{tabular}




\begin{tabular}{|l|l|l|}
\hline Log of assets & financing to the company prior to committing the infraction. & company and date. \\
\hline Hermitage stake & $\begin{array}{l}\text { Log of assets is the log of book value of fixed assets in 1999. } \\
\text { Capital had a stake in the company based on their reported } \\
\text { portfolio composition at the end of 1998, the earliest available } \\
\text { date for the Hermitage fund. }\end{array}$ & $\begin{array}{l}\text { Hermitage Fund Consolidated Financial Statements, } \\
1998 .\end{array}$ \\
\hline
\end{tabular}




\section{Table 4: Types of Alleged Corporate Governance Violations and Outcomes}

For each alleged violation, this table reports its type, the maximum potential loss, the outcome, and for those with a positive outcome, a description of notable events regarding the outcome. We include 7 mutually exclusive categories of alleged violation, which include disenfranchisement and six types of dilution (Share Issuance, Share Swap, Reorganization, Bankruptcy, Asset Stripping and Other).The maximum potential loss variable assumes the proposed action went through and the worst fears were realized for minority shareholders. When the action is a disenfranchisement, we use a three point scale from lowest (1) to highest (3) severity of the potential loss. For each alleged violation we code the outcome equal to 0 if it was not redressed at all, 1 if partially redressed, and 2 if substantially redressed. The outcome description is based on our reading of the English and Russian press and Troika Dialog's "Bulletin on Corporate Governance Actions.”

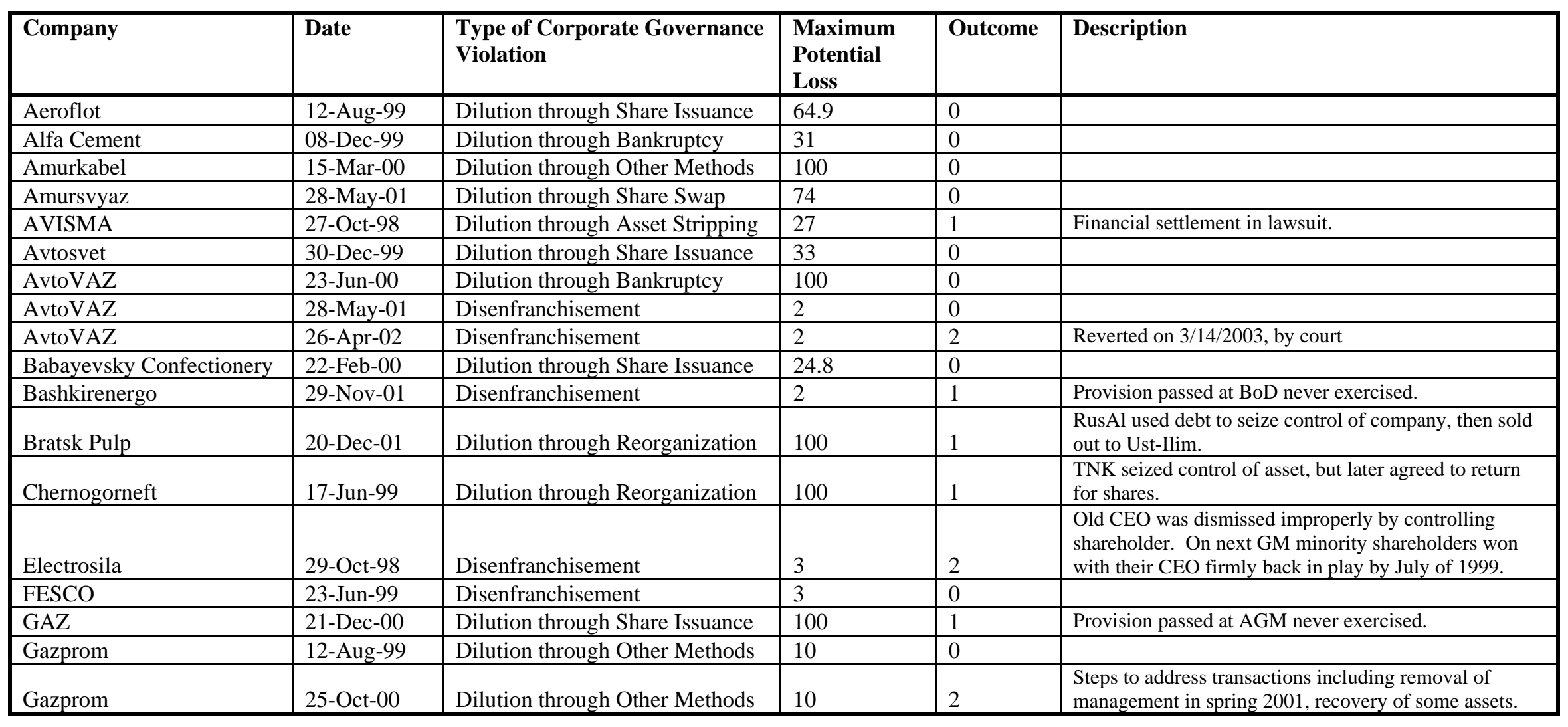




\begin{tabular}{|c|c|c|c|c|c|}
\hline Gazprom & 11-May-01 & Disenfranchisement & 2 & 2 & $\begin{array}{l}\text { CEO replaced in advance of AGM, followed by removal } \\
\text { of restriction on UFG shares, with Fyodorov gaining } \\
\text { seat at AGM. }\end{array}$ \\
\hline Irkutskelectrosvyaz & 23-Sep-99 & Disenfranchisement & 2 & 2 & $\begin{array}{l}\text { On March 1, 2000, Irkutsk Region arbiters ruled the } \\
\text { Irkutskelectrosvyaz EGM decision to announce } 1998 \\
\text { preferred dividends illegal. }\end{array}$ \\
\hline Izhorsk Works & 23-Jun-00 & Dilution through Share Issuance & 44 & 0 & \\
\hline Kaluganefteproduct & 11-Mar-00 & Dilution through Share Swap & 100 & 0 & \\
\hline KamAZ & 02-Sep-99 & Dilution through Reorganization & 80 & 1 & $\begin{array}{l}\text { Share issue goes through. EBRD challenges case, } \\
\text { initiating lawsuits, eventual agreement whereby } \\
\text { transform half of debt into equity ( } 4-5 \% \text { ) and remaining } \\
\text { half into rescheduled debt backed by the government. }\end{array}$ \\
\hline Kazan Helicopter & 17-Jun-99 & Disenfranchisement & 1 & 0 & \\
\hline Khantymansiiskokrtelecom & 25-Jul-01 & Dilution through Share Swap & 70 & 0 & \\
\hline KomiTEK & 30-Jun-99 & Dilution through Share Issuance & & 1 & $\begin{array}{l}\text { The allowance for large shareholders to buy extra shares } \\
\text { was not exercised. }\end{array}$ \\
\hline Krasnoyarsk GES & 23-Jun-99 & Dilution through Share Issuance & 33 & 0 & \\
\hline Krasnoyarsk GES & 08-Jun-00 & Disenfranchisement & 1 & 0 & \\
\hline Krasnoyarsk Tire & 20-Jan-00 & Dilution through Bankruptcy & 100 & 0 & \\
\hline KrAZ & 07-Jun-99 & Dilution through Share Issuance & 50 & 0 & \\
\hline KrAZ & 03-Feb-00 & Dilution through Share Issuance & 33 & 2 & Shareholders declined the agenda of EGM. \\
\hline Kuzbassugol & 03-Aug-00 & Disenfranchisement & 1 & 0 & \\
\hline Kuznetsk Ferrous Alloys & 22-May-01 & Dilution through Share Issuance & 86 & 2 & $\begin{array}{l}\text { On October 26, } 2001 \text { FCSM refused to register new } \\
\text { issue. }\end{array}$ \\
\hline Lakokraska & 07-Sep-00 & Dilution through Share Issuance & 50 & 0 & \\
\hline Leningrad Metal Plant & 05-Oct-99 & Dilution through Share Issuance & 54 & 0 & \\
\hline Leningrad Metal Plant & 03-Apr-00 & Dilution through Reorganization & 70 & 0 & \\
\hline Lomonosov Porcelain & 01-Jul-99 & Dilution through Other Methods & 100 & 2 & $\begin{array}{l}\text { Private investors managed to overturn the court decision } \\
\text { and got company back. }\end{array}$ \\
\hline Moscow Refinery & 03-May-00 & Disenfranchisement & 1 & 0 & \\
\hline Mosenergo & 09-Feb-99 & Dilution through Share Issuance & 9.5 & 0 & \\
\hline Mosenergo & 12-Jul-01 & Disenfranchisement & 2 & 0 & \\
\hline NefAZ & 25-Jan-99 & Dilution through Share Issuance & 57 & 0 & \\
\hline Nizhnevartovskneftegaz & 15-Jan-99 & Dilution through Share Swap & 27 & 0 & \\
\hline $\begin{array}{l}\text { Nizhnevartovsk Oil \& Gas } \\
\text { Production }\end{array}$ & 06-Sep-01 & Dilution through Share Swap & 85 & 0 & \\
\hline Nizhniy Tagil Metal Plant & 25-May-00 & Disenfranchisement & 2 & 0 & \\
\hline
\end{tabular}




\begin{tabular}{|c|c|c|c|c|c|}
\hline Norilsk Nickel & 15-Jun-00 & Dilution through Share Swap & 27.5 & 0 & \\
\hline Norilsk Nickel & 18-Sep-00 & Dilution through Share Swap & 11 & 0 & \\
\hline North Western Telecom & 18-Feb-02 & Dilution through Other Methods & & 0 & \\
\hline NOSTA & 23-Jun-99 & Dilution through Share Issuance & 33 & 0 & \\
\hline NOSTA & 07-Oct-99 & Dilution through Reorganization & 100 & 0 & \\
\hline Novolipetsk Metal & 27-Jan-99 & Dilution through Share Issuance & 50 & 0 & \\
\hline Novolipetsk Metal & 13-Jul-00 & Dilution through Other Methods & 5 & 0 & \\
\hline Novorossiisk Shipping & 19-Apr-01 & Dilution through Other Methods & 8 & 1 & $\begin{array}{l}\text { State Property Fund cancelled the deal to strip assets } \\
\text { from Novoship to offshore company. }\end{array}$ \\
\hline Novosibirskenergo & 04-Apr-01 & Disenfranchisement & 2 & 0 & \\
\hline Noyabrskneftegaz & 01-Dec-98 & Dilution through Share Swap & & 0 & \\
\hline Noyabrskneftegaz & 27-Dec-00 & Disenfranchisement & 3 & 0 & \\
\hline Omskenergo & 05-Nov-01 & Disenfranchisement & 1 & 0 & \\
\hline Orenburgneft & 28-Apr-00 & Disenfranchisement & 1 & 0 & \\
\hline Petmol Dairy & 01-Feb-00 & Disenfranchisement & 2 & 0 & \\
\hline Purneftegaz & 12-Apr-00 & Disenfranchisement & 3 & 0 & \\
\hline Purneftegaz & 06-Jul-01 & Dilution through Other Methods & 80 & 0 & \\
\hline Purneftegaz & 18-Feb-02 & Dilution through Other Methods & 66 & 0 & \\
\hline RAO UES & 05-Apr-00 & Dilution through Bankruptcy & 100 & 1 & $\begin{array}{l}\text { Reorganization plan radically altered in face of protests } \\
\text { and publicity. }\end{array}$ \\
\hline Rospan & 20-May-00 & Dilution through Reorganization & 100 & 0 & \\
\hline Rosshelf & 07-Feb-02 & Dilution through Share Issuance & 97 & 2 & $\begin{array}{l}\text { On June 27, } 2002 \text { Lukoil managed to block the decision } \\
\text { to issue new shares proposed by Gazprom }\end{array}$ \\
\hline Rostselmash & 12-Apr-98 & Dilution through Other Methods & 8 & 0 & \\
\hline Sakhalinmorneftegaz & 14-Mar-00 & Disenfranchisement & 2 & 0 & \\
\hline Sakhaneftegaz & $16-F e b-00$ & Dilution through Share Issuance & 30.5 & 0 & \\
\hline Samaraneftegaz & 24-Feb-99 & Dilution through Share Issuance & 75 & 0 & \\
\hline Samotlorneftegaz & 18-Feb-99 & Dilution through Share Swap & 27 & 0 & \\
\hline Samotlorneftegaz & 06-Sep-01 & Disenfranchisement & 3 & 0 & . \\
\hline Samson & 04-Jul-00 & Dilution through Reorganization & 20 & 0 & \\
\hline Sberbank & 27-Dec-00 & Dilution through Share Issuance & 26.3 & 1 & $\begin{array}{l}\text { Dilutive issues go through, but minorities get board seat } \\
\text { and later law passed limiting future issues }\end{array}$ \\
\hline Sibneftegazpererabotka & 22-Jun-99 & Dilution through Reorganization & 100 & 0 & \\
\hline SibUr-Neftekhim & 03-Aug-00 & Disenfranchisement & 3 & 0 & \\
\hline Sidanco & 07-Apr-99 & Dilution through Reorganization & 100 & 1 & $\begin{array}{l}\text { BP and Interros eventually agree to a deal that allows } \\
\text { them to get the company out of bankruptcy. }\end{array}$ \\
\hline
\end{tabular}




\begin{tabular}{|c|c|c|c|c|c|}
\hline Slavneft-Megionneftegaz & 06-Jul-00 & Disenfranchisement & 3 & 0 & \\
\hline Stepan Razin Brewery & 08-Dec-99 & Dilution through Share Issuance & 50 & 0 & \\
\hline SUAL & 11-Nov-01 & Dilution through Share Issuance & 72 & 0 & \\
\hline Surgutneftegaz & 24-Jan-00 & Dilution through Share Swap & 19.4 & 0 & \\
\hline TNK-Nyagan & 06-Sep-01 & Disenfranchisement & 3 & 0 & \\
\hline Tomsk Refinery & 24-Jun-99 & Dilution through Share Issuance & 20 & 2 & $\begin{array}{l}\text { On October 4, } 1999 \text { the FCSM (national securities } \\
\text { regulator) cancelled the new issue }\end{array}$ \\
\hline Tomskneft VNK & 24-Feb-99 & Dilution through Share Issuance & 29 & 2 & $\begin{array}{l}\text { On January 17, } 2000 \text { the FCSM suspended the } \\
\text { Tomskneft share issue prospectus. }\end{array}$ \\
\hline Transneft & 08-Jul-99 & Disenfranchisement & 2 & 1 & $\begin{array}{l}\text { On July 3, 2000, the general meeting approved the } \\
\text { paying of dividends for } 1997\end{array}$ \\
\hline Tulanefteproduct & 08-Dec-99 & Dilution through Share Issuance & 37.1 & 0 & \\
\hline Tyumenneftegaz & 06-Sep-01 & Disenfranchisement & 3 & 0 & \\
\hline Ugraneft & 29-Jun-01 & Disenfranchisement & 3 & 0 & \\
\hline Uralkaly & 25-May-00 & Disenfranchisement & 1 & 0 & \\
\hline $\begin{array}{l}\text { Ust Illimsk Timber } \\
\text { Concern }\end{array}$ & 27-Aug-01 & Dilution through Bankruptcy & 100 & 1 & $\begin{array}{l}\text { The bankruptcy proceedings were ceased and assets } \\
\text { were returned to Rosprom. }\end{array}$ \\
\hline Vannady & 04-Nov-00 & Dilution through Reorganization & 90 & 0 & \\
\hline Viksunsk Pipe & 26-Jan-99 & Dilution through Share Issuance & 45 & 1 & $\begin{array}{l}\text { Agreement was achieved between shareholders and } \\
\text { managers, with support of FCSM and NAUFOR. }\end{array}$ \\
\hline Vladimir Tractor & 01-Jun-00 & Disenfranchisement & 2 & 0 & \\
\hline Volgotanker & 10-Mar-99 & Dilution through Reorganization & 100 & 1 & $\begin{array}{l}\text { On May 27, at the General Meeting the regional } \\
\text { authority owning } 20 \% \text { of the company voted against the } \\
\text { restructuring plan proposed by Yukos. Still Yukos } \\
\text { managed to appoint its CEO. }\end{array}$ \\
\hline VSMPO & 28-Nov-98 & Disenfranchisement & 1 & 0 & \\
\hline VSMPO & 01-Sep-99 & Disenfranchisement & 2 & 1 & $\begin{array}{l}\text { Suit to force minority investors in VSMPO is dropped, } \\
\text { and investors agree to exit firm. }\end{array}$ \\
\hline Yakutskenergo & 19-Oct-00 & Dilution through Asset Stripping & & 0 & \\
\hline YANOS & 28-Apr-00 & Dilution through Share Issuance & 48.5 & 0 & \\
\hline Yuganskneftegaz & 24-Mar-99 & Dilution through Share Swap & 70 & 1 & $\begin{array}{l}\text { Conflict between FCSM and Yukos. FCSM stop trading } \\
\text { of Yukos shares on RTS and Yukos was forced to } \\
\text { switch to another stock exchange. Yukos doubled the } \\
\text { swap ratio. }\end{array}$ \\
\hline Yukos & 1-Jun-99 & Dilution through Share Issuance & 20 & 0 & \\
\hline
\end{tabular}




\section{Table 5: News Coverage of Alleged Corporate Governance Violations}

This table reports our primary measures of news coverage used in tables 8-10. The number of articles in English newspapers (WSJ and FT) and in Russian papers (Kommersant, Izvestia and Vedemosti) is based on a count of the number of articles mentioning a company in the specified newspaper during the period from $\mathrm{t}-1$ month to $\mathrm{t}+2$ months after the date of the alleged violation. The measures of newsworthiness are based upon a 6-month period prior to the violation and before the Russian currency crises.

\begin{tabular}{|c|c|c|c|c|c|}
\hline Company & Date & $\begin{array}{l}\text { \# of articles } \\
\text { in English } \\
\text { newspapers: } \\
\text { WSJ and } \\
\text { Financial } \\
\text { Times }\end{array}$ & $\begin{array}{l}\text { \# of articles } \\
\text { in Russian } \\
\text { newspapers: } \\
\text { Kommersant, } \\
\text { Izvestia and } \\
\text { Vedomosti }\end{array}$ & $\begin{array}{l}\text { Newsworthiness- } \\
\text { coverage in } \\
\text { English } \\
\text { newspapers } \\
\text { January-June } \\
1998\end{array}$ & $\begin{array}{c}\text { Newsworthiness- } \\
\text { coverage in } \\
\text { Russian } \\
\text { newspapers } \\
\text { January-June } \\
1998\end{array}$ \\
\hline Aeroflot & 12-Aug-99 & 0 & 0 & 7 & 97 \\
\hline Alfa Cement & 08-Dec-99 & 0 & 0 & 0 & 2 \\
\hline Amurkabel & 15-Mar-00 & 0 & 0 & 0 & 0 \\
\hline Amursvyaz & 28-May-01 & 0 & 0 & 0 & 0 \\
\hline AVISMA & 27-Oct-98 & 0 & 0 & 0 & 1 \\
\hline Avtosvet & 30-Dec-99 & 0 & 0 & 0 & 0 \\
\hline AvtoVAZ & 23-Jun-00 & 0 & 3 & 2 & 92 \\
\hline AvtoVAZ & 28-May-01 & 0 & 6 & 2 & 92 \\
\hline AvtoVAZ & 26-Apr-02 & 0 & 2 & 2 & 92 \\
\hline $\begin{array}{l}\text { Babayevsky } \\
\text { Confectionery }\end{array}$ & 22-Feb-00 & 0 & 5 & 0 & 6 \\
\hline Bashkirenergo & 29-Nov-01 & 0 & 0 & 0 & 1 \\
\hline Bratsk Pulp & 20-Dec-01 & 0 & 6 & 0 & 0 \\
\hline Chernogorneft & 17-Jun-99 & 5 & 4 & 0 & 5 \\
\hline Electrosila & 29-Oct-98 & 0 & 0 & 0 & 2 \\
\hline FESCO & 23-Jun-99 & 0 & 3 & 0 & 8 \\
\hline GAZ & 21-Dec-00 & 1 & 5 & 4 & 35 \\
\hline Gazprom & 12-Aug-99 & 0 & 1 & 110 & 381 \\
\hline Gazprom & 25-Oct-00 & 16 & 6 & 110 & 381 \\
\hline Gazprom & 11-May-01 & 7 & 21 & 110 & 381 \\
\hline Irkutskelectrosvyaz & 23-Sep-99 & 0 & 0 & 0 & 0 \\
\hline Izhorsk Works & 23-Jun-00 & 0 & 0 & 0 & 8 \\
\hline Kaluganefteproduct & 11-Mar-00 & 0 & 0 & 0 & 0 \\
\hline KamAZ & 02-Sep-99 & 0 & 0 & 0 & 94 \\
\hline Kazan Helicopter & 17-Jun-99 & 0 & 0 & 0 & 4 \\
\hline Khantyman & 25-Jul-01 & 0 & 2 & 0 & 0 \\
\hline KomiTEK & 30-Jun-99 & 0 & 3 & 0 & 4 \\
\hline Krasnoyarsk GES & 23-Jun-99 & 0 & 0 & 1 & 7 \\
\hline Krasnoyarsk GES & 08-Jun-00 & 0 & 0 & 1 & 7 \\
\hline Krasnoyarsk Tire & 20-Jan-00 & 0 & 0 & 0 & 0 \\
\hline KrAZ & 07-Jun-99 & 1 & 1 & 0 & 21 \\
\hline $\mathrm{KrAZ}$ & 03-Feb-00 & 0 & 3 & 0 & 21 \\
\hline Kuzbassugol & 03-Aug-00 & 0 & 1 & 0 & 0 \\
\hline Kuznetsk Ferrous Alloys & 22-May-01 & 0 & 0 & 0 & 0 \\
\hline Lakokraska & 07-Sep-00 & 0 & 0 & 0 & 0 \\
\hline Leningrad Metal Zavod & 05-Oct-99 & 0 & 0 & 0 & 4 \\
\hline Leningrad Metal Zavod & 03-Apr-00 & 0 & 4 & 0 & 3 \\
\hline Lomonosov Porcelain & 01-Jul-99 & 0 & 1 & 0 & 0 \\
\hline Moscow Refinery & 03-May-00 & 0 & 1 & 0 & 11 \\
\hline Mosenergo & 09-Feb-99 & 0 & 0 & 0 & 39 \\
\hline
\end{tabular}




\begin{tabular}{|c|c|c|c|c|c|}
\hline Mosenergo & 12-Jul-01 & 2 & 47 & 0 & 39 \\
\hline NefAZ & 25-Jan-99 & 0 & 1 & 0 & 11 \\
\hline $\begin{array}{l}\text { Nizhnevartovsk Oil \& } \\
\text { Gas Production }\end{array}$ & 06-Sep-01 & 0 & 1 & 0 & 0 \\
\hline $\begin{array}{l}\text { Nizhnevartovsk Oil \& } \\
\text { Gaz Production }\end{array}$ & 15-Jan-99 & 0 & 1 & 0 & 11 \\
\hline Nizhniy Tagil Metal Plant & 25-May-00 & 0 & 1 & 0 & 11 \\
\hline Norilsk Nickel & 15-Jun-00 & 0 & 5 & 9 & 45 \\
\hline Norilsk Nickel & 18-Sep-00 & 8 & 18 & 9 & 45 \\
\hline North Western Telecom & 18-Feb-02 & 0 & 3 & 0 & 0 \\
\hline NOSTA & 23-Jun-99 & 0 & 1 & 0 & 11 \\
\hline NOSTA & 07-Oct-99 & 0 & 1 & 0 & 11 \\
\hline Novolipetsk Metal & 27-Jan-99 & 0 & 1 & 2 & 25 \\
\hline Novolipetsk Metal & 13-Jul-00 & 0 & 1 & 2 & 25 \\
\hline Novorossiisk Shipping & 19-Apr-01 & 0 & 1 & 0 & 11 \\
\hline Novosibirskenergo & 04-Apr-01 & 0 & 4 & 0 & 6 \\
\hline Noyabrskneftegas & 01-Dec-98 & 0 & 3 & 0 & 15 \\
\hline Noyabrskneftegas & 27-Dec-00 & 0 & 1 & 2 & 15 \\
\hline Omskenergo & 05-Nov-01 & 0 & 1 & 0 & 11 \\
\hline Orenburgneft & 28-Apr-00 & 0 & 10 & 0 & 4 \\
\hline Petmol & $01-$ Feb-00 & 0 & 2 & 0 & 4 \\
\hline Purneftegaz & 12-Apr-00 & 0 & 1 & 0 & 11 \\
\hline Purneftegaz & 06-Jul-01 & 0 & 1 & 0 & 5 \\
\hline Purneftegaz & 18-Feb-02 & 0 & 3 & 0 & 5 \\
\hline RAO UES & 05-Apr-00 & 5 & 16 & 30 & 230 \\
\hline Rospan & 20-May-00 & 0 & 1 & 0 & 11 \\
\hline Rosshelf & 07-Feb-02 & 0 & 1 & 0 & 11 \\
\hline Rostselmash & 12-Apr-98 & 0 & 1 & 0 & 11 \\
\hline Sakhalinmorneftegaz & 14-Mar-00 & 0 & 1 & 0 & 8 \\
\hline Sakhaneftegaz & $16-$ Feb-00 & 0 & 0 & 0 & 1 \\
\hline Samaraneftegaz & 24-Feb-99 & 3 & 1 & 0 & 6 \\
\hline Samotlorneftegaz & 18-Feb-99 & 0 & 1 & 0 & 11 \\
\hline Samotlorneftegaz & 06-Sep-01 & 0 & 3 & 0 & 0 \\
\hline Samson & 04-Jul-00 & 0 & 1 & 0 & 11 \\
\hline Sberbank & 27-Dec-00 & 3 & 3 & 6 & 212 \\
\hline Sibneftegazpererabotka & 22-Jun-99 & 0 & 0 & 0 & 0 \\
\hline SibUr & 03-Aug-00 & 0 & 5 & 0 & 0 \\
\hline Sidanco & 07-Apr-99 & 4 & 5 & 40 & 58 \\
\hline Slavneft-Megionneftegaz & 06-Jul-00 & 1 & 6 & 0 & 14 \\
\hline Stepan Razin Brewery & 08-Dec-99 & 0 & 1 & 0 & 11 \\
\hline SUAL & 11-Nov-01 & 0 & 1 & 0 & 11 \\
\hline Surgutneftegaz & 24-Jan-00 & 5 & 12 & 1 & 41 \\
\hline TNK-Nyagan & 06-Sep-01 & 0 & 1 & 0 & 0 \\
\hline Tomsk Refinery & 24-Jun-99 & 0 & 0 & 0 & 0 \\
\hline Tomskneft VNK & 24-Feb-99 & 4 & 1 & 2 & 5 \\
\hline Transneft & 08-Jul-99 & 0 & 0 & 3 & 7 \\
\hline Tulanefteproduct & 08-Dec-99 & 0 & 0 & 0 & 0 \\
\hline Tyumenneftegaz & 06-Sep-01 & 0 & 2 & 0 & 1 \\
\hline Ugraneft & 29-Jun-01 & 0 & 1 & 5 & 11 \\
\hline Uralkaly & 25-May-00 & 0 & 0 & 0 & 2 \\
\hline Ust Illimsk Timber Mill & 27-Aug-01 & 0 & 5 & 0 & 2 \\
\hline Vanady & 04-Nov-00 & 0 & 1 & 0 & 11 \\
\hline
\end{tabular}




\begin{tabular}{|l|c|c|c|c|c|}
\hline Viksunsk Pipe & 26-Jan-99 & 0 & 0 & 0 & 0 \\
\hline Vladimir Tractor & 01-Jun-00 & 0 & 1 & 1 & 11 \\
\hline Volgotanker & 10-Mar-99 & 0 & 1 & 0 & 11 \\
\hline VSMPO & 28-Nov-98 & 0 & 0 & 0 & 0 \\
\hline VSMPO & 01-Sep-99 & 1 & 5 & 0 & 1 \\
\hline Yakutskenergo & 19-Oct-00 & 0 & 1 & 0 & 1 \\
\hline YANOS & 28-Apr-00 & 0 & 1 & 0 & 11 \\
\hline Yuganskneftegaz & 24-Mar-99 & 3 & 1 & 0 & 10 \\
\hline YUKOS & 08-Jun-99 & 1 & 1 & 39 & 90 \\
\hline
\end{tabular}




\section{Table 6: Control Variables}

This table reports control variables used in our main regressions (Table 8-10). Foreign ownership is the proportion of stock held by foreign investors. EBRD is a dummy variable equal to 1 if the EBRD has provided loan financing to the company prior to committing the infraction. Log of assets is the log of book value of fixed assets in 1999. The last column is the percentage of the Hermitage fund invested in each of the companies involved as of December 1998. For the 5 companies with an event before December 1998 we use the December 1998 holdings unless we know from the financial statement when the stake was acquired or disposed.

\begin{tabular}{|c|c|c|c|c|}
\hline Company & Date & $\begin{array}{c}\text { Foreign } \\
\text { ownership } \\
\text { stake }\end{array}$ & EBRD stake & $\begin{array}{c}\text { \% of Hermitage } \\
\text { invested in company }\end{array}$ \\
\hline Aeroflot & 12-Aug-99 & 0.2 & 0 & 0.00 \\
\hline Alfa Cement & 08-Dec-99 & 0.5 & 0 & 0.00 \\
\hline Amurkabel & 15-Mar-00 & 0 & 0 & 0.00 \\
\hline Amursvyaz & 28-May-01 & 0 & 0 & 0.00 \\
\hline AVISMA & 27-Oct-98 & 0.58 & 0 & 0.03 \\
\hline Avtosvet & 30-Dec-99 & 0.216 & 0 & 0.00 \\
\hline AvtoVAZ & 23-Jun-00 & 0 & 0 & 0.00 \\
\hline AvtoVAZ & 28-May-01 & 0 & 1 & 0.00 \\
\hline AvtoVAZ & 26-Apr-02 & 0 & 1 & 0.00 \\
\hline Babayevsky Confectionery & 22-Feb-00 & 0 & 0 & 0.00 \\
\hline Bashkirenergo & 29-Nov-01 & 0 & 0 & 0.00 \\
\hline Bratsk Pulp & 20-Dec-01 & 0 & 0 & 0.00 \\
\hline Chernogorneft & 17-Jun-99 & 0.184 & 1 & 0.00 \\
\hline Electrosila & 29-Oct-98 & 0.24 & 0 & 0.00 \\
\hline FESCO & 23-Jun-99 & 0.4 & 1 & 0.00 \\
\hline GAZ & 21-Dec-00 & 0.2 & 1 & 0.00 \\
\hline Gazprom & 12-Aug-99 & 0.058 & 0 & 0.10 \\
\hline Gazprom & 25-Oct-00 & 0.1 & 0 & 0.10 \\
\hline Gazprom & 11-May-01 & 0.11 & 0 & 0.10 \\
\hline Irkutskelectrosvyaz & 23-Sep-99 & 0.026 & 0 & 0.00 \\
\hline Izhorsk Works & 23-Jun-00 & 0 & 0 & 0.00 \\
\hline Kaluganefteproduct & 11-Mar-00 & 0 & 0 & 0.00 \\
\hline KamAZ & 02-Sep-99 & 0.26 & 1 & 0.00 \\
\hline Kazan Helicopter & 17-Jun-99 & 0.072 & 0 & 0.00 \\
\hline Khantyman & 25-Jul-01 & 0.065 & 0 & 0.00 \\
\hline KomiTEK & 30-Jun-99 & 0.1 & 0 & 0.01 \\
\hline Krasnoyarsk GES & 23-Jun-99 & 0.13 & 0 & 0.00 \\
\hline Krasnoyarsk GES & 08-Jun-00 & 0.13 & 0 & 0.00 \\
\hline Krasnoyarsk Tire & 20-Jan-00 & 0 & 0 & 0.00 \\
\hline KrAZ & 07-Jun-99 & 0.14 & 0 & 0.00 \\
\hline $\mathrm{KrAZ}$ & 03-Feb-00 & 0.14 & 0 & 0.00 \\
\hline Kuzbassugol & 03-Aug-00 & 0 & 0 & 0.00 \\
\hline Kuznetsk Ferrous Alloys & 22-May-01 & 0 & 0 & 0.00 \\
\hline Lakokraska & 07-Sep-00 & 0 & 0 & 0.00 \\
\hline
\end{tabular}




\begin{tabular}{|c|c|c|c|c|}
\hline Leningrad Metal Zavod & 05-Oct-99 & 0.1 & 0 & 0.00 \\
\hline Leningrad Metal Zavod & 03-Apr-00 & 0.147 & 0 & 0.00 \\
\hline Lomonosov Porcelain & 01-Jul-99 & 0.84 & 0 & 0.00 \\
\hline Moscow Refinery & 03-May-00 & 0 & 0 & 0.00 \\
\hline Mosenergo & 09-Feb-99 & 0.35 & 1 & 0.01 \\
\hline Mosenergo & 12-Jul-01 & 0.29 & 1 & 0.01 \\
\hline NefAZ & 25-Jan-99 & 0.22 & 0 & 0.00 \\
\hline Nizhnevartovsk Oil \& Gas Production & 15-Jan-99 & 0.23 & 0 & 0.00 \\
\hline Nizhnevartovsk Oil \& Gas Production & 06-Sep-01 & 0 & 0 & 0.00 \\
\hline Nizhniy Tagil Metal Plant & 25-May-00 & 0.2 & 0 & 0.00 \\
\hline \begin{tabular}{|l} 
Norilsk Nickel \\
\end{tabular} & 15-Jun-00 & 0.2 & 0 & 0.00 \\
\hline Norilsk Nickel & 18-Sep-00 & 0.2 & 0 & 0.00 \\
\hline North Western Telecom & 18-Feb-02 & 0.286 & 0 & 0.00 \\
\hline NOSTA & 23-Jun-99 & 0.19 & 0 & 0.00 \\
\hline NOSTA & 07-Oct-99 & 0.19 & 0 & 0.00 \\
\hline Novolipetsk Metal & 27-Jan-99 & 0.4 & 0 & 0.00 \\
\hline Novolipetsk Metal & 13-Jul-00 & 0.4 & 0 & 0.00 \\
\hline Novorossiisk Shipping & 19-Apr-01 & 0.1 & 1 & 0.00 \\
\hline Novosibirskenergo & 04-Apr-01 & 0 & 0 & 0.00 \\
\hline Noyabrskneftegas & 01-Dec-98 & 0 & 0 & 0.00 \\
\hline Noyabrskneftegas & 27-Dec-00 & 0 & 0 & 0.00 \\
\hline Omskenergo & 05-Nov-01 & 0 & 0 & 0.00 \\
\hline Orenburgneft & 28-Apr-00 & 0 & 0 & 0.00 \\
\hline Petmol & 01-Feb-00 & 0.37 & 0 & 0.00 \\
\hline Purneftegaz & 12-Apr-00 & 0.31 & 0 & 0.00 \\
\hline Purneftegaz & 06-Jul-01 & 0.404 & 0 & 0.00 \\
\hline Purneftegaz & 18-Feb-02 & 0.404 & 0 & 0.00 \\
\hline RAO UES & 05-Apr-00 & 0.33 & 0 & 0.09 \\
\hline Rospan & 20-May-00 & 0 & 0 & 0.00 \\
\hline Rosshelf & 07-Feb-02 & 0 & 0 & 0.00 \\
\hline Rostselmash & 12-Apr-98 & 0 & 0 & 0.00 \\
\hline Sakhalinmorneftegaz & 14-Mar-00 & 0.106 & 1 & 0.00 \\
\hline \begin{tabular}{|l} 
Sakhaneftegaz \\
\end{tabular} & $16-$ Feb-00 & 0 & 0 & 0.00 \\
\hline Samaraneftegaz & 24-Feb-99 & 0.15 & 0 & 0.00 \\
\hline Samotlorneftegaz & 18-Feb-99 & 0.18 & 0 & 0.00 \\
\hline Samotlorneftegaz & 06-Sep-01 & 0 & 0 & 0.00 \\
\hline Samson & 04-Jul-00 & 0 & 0 & 0.00 \\
\hline Sberbank & 27-Dec-00 & 0.119 & 1 & 0.03 \\
\hline Sibneftegazpererabotka & 22-Jun-99 & 0.113 & 0 & 0.00 \\
\hline SibUr & 03-Aug-00 & 0 & 0 & 0.00 \\
\hline Sidanco & 07-Apr-99 & 0.12 & 0 & 0.02 \\
\hline \begin{tabular}{|l} 
Slavneft-Megionneftegaz \\
\end{tabular} & 06-Jul-00 & 0.126 & 0 & 0.00 \\
\hline Stepan Razin Brewery & 08-Dec-99 & 0 & 0 & 0.00 \\
\hline SUAL & 11-Nov-01 & 0 & 0 & 0.00 \\
\hline Surgutneftegaz & 24-Jan-00 & 0.31 & 0 & 0.06 \\
\hline
\end{tabular}




\begin{tabular}{|l|c|c|c|c|}
\hline TNK-Nyagan & 06-Sep-01 & 0 & 0 & 0.00 \\
\hline Tomsk Refinery & 24-Jun-99 & 0 & 0 & 0.00 \\
\hline Tomskneft VNK & 24-Feb-99 & 0.2 & 0 & 0.00 \\
\hline Transneft & 08-Jul-99 & 0 & 1 & 0.00 \\
\hline Tulanefteproduct & 08-Dec-99 & 0 & 0 & 0.00 \\
\hline Tyumenneftegaz & 06-Sep-01 & 0 & 0 & 0.00 \\
\hline Ugraneft & 29-Jun-01 & 0 & 0 & 0.00 \\
\hline Uralkaly & 25-May-00 & 0 & 0 & 0.00 \\
\hline Ust Illimsk Timber Mill & 27-Aug-01 & 0 & 0 & 0.00 \\
\hline Vanady & 04-Nov-00 & 0 & 0 & 0.03 \\
\hline Viksunsk Pipe & 26-Jan-99 & 0 & 0 & 0.00 \\
\hline Vladimir Tractor & 01-Jun-00 & 0 & 0 & 0.00 \\
\hline Volgotanker & 10-Mar-99 & 0.3 & 0 & 0.00 \\
\hline VSMPO & 28-Nov-98 & 0.08 & 0 & 0.00 \\
\hline VSMPO & 01-Sep-99 & 0.38 & 0 & 0.03 \\
\hline Yakutskenergo & 19-Oct-00 & 0 & 0 & 0.00 \\
\hline YANOS & 28-Apr-00 & 0.3 & 0 & 0.00 \\
\hline Yuganskneftegaz & 24-Mar-99 & 0.15 & 0 & 0.00 \\
\hline YUKOS & 08-Jun-99 & 0.32 & 0 & 0.01 \\
\hline
\end{tabular}




\section{Table 7: Summary Statistics}

This table reports summary statistics for variables included in tables 8-10. Foreign ownership is the proportion of stock held by foreign investors. EBRD is a dummy variable equal to 1 if the EBRD has provided loan financing to the company prior to committing the infraction. Log of assets is the log of fixed assets for 1999. The oil industry dummy identifies firms in the oil and gas industry. The number of articles is based on a count in the period from $\mathrm{t}-1$ month to $\mathrm{t}+2$ months after the proposed violation. The measures of natural newsworthiness are based on the same publications in January-July 1998. We include 7 mutually exclusive categories of alleged violation, which include disenfranchisement and six types of dilution (Share Issuance, Share Swap, Reorganization, Bankruptcy, Asset Stripping and Other). The maximum potential loss variable assumes the proposed actions went through and the worst fears were realized for minority shareholders. When the violation is a disenfranchisement, we use a three point scale from lowest (1) to highest (3) severity of the potential loss.

\begin{tabular}{|c|c|c|c|c|c|c|}
\hline Outcome & Mean & Median & $\begin{array}{l}\text { Standard } \\
\text { Deviation }\end{array}$ & Minimum & Maximum & $\begin{array}{l}\text { Number } \\
\text { of obser- } \\
\text { vations }\end{array}$ \\
\hline Foreign ownership & 0.13 & .1 & 0.16 & 0 & .84 & 98 \\
\hline Dummy for EBRD stake & 0.12 & 0 & 0.33 & 0 & 1 & 98 \\
\hline Log assets & 14.88 & 14.87 & 1.99 & 10.07 & 20.9 & 98 \\
\hline Oil Industry dummy & 0.01 & 0 & 0.02 & 0 & 1 & 98 \\
\hline \# articles in FT \& WSJ & 0.71 & 0 & 2.18 & 0 & 16 & 98 \\
\hline Log of (1+ \# articles in FT+WSJ) & 0.25 & 0 & 0.6 & 0 & 2.83 & 98 \\
\hline $\begin{array}{l}\text { Natural newsworthiness (log of (1+ \# } \\
\text { articles in FT+WSJ) January-July 1998) }\end{array}$ & 0.5 & 0 & 1.1 & 0 & 4.71 & 98 \\
\hline Log of (1+ \# articles in FT) & 0.2 & 0 & 0.5 & 0 & 2.48 & 98 \\
\hline Log of (1+ \# articles in WSJ) & 0.12 & 0 & 0.36 & 0 & 1.79 & 98 \\
\hline Log of (1+ \# articles in Russian press) & 0.77 & 0.69 & 0.77 & 0 & 3.56 & 98 \\
\hline Log of (1+ \# articles in Vedomosti) & 0.43 & 0 & 0.56 & 0 & 2.64 & 98 \\
\hline \multicolumn{7}{|l|}{ Type of Dilutions } \\
\hline Share issuance & 0.29 & 0 & 0.45 & 0 & 1 & 98 \\
\hline Share swap & 0.11 & 0 & 0.32 & 0 & 1 & 98 \\
\hline Bankruptcy & 0.1 & 0 & 0.3 & 0 & 1 & 98 \\
\hline Reorganization & 0.06 & 0 & 0.24 & 0 & 1 & 98 \\
\hline Asset stripping & 0.02 & 0 & 0.14 & 0 & 1 & 98 \\
\hline Other forms of dilutions & 0.1 & 0 & 0.3 & 0 & 1 & 98 \\
\hline Disenfranchisement & 0.32 & 0 & 0.47 & 0 & 1 & 98 \\
\hline Maximum Loss in Dilution & 0.57 & 50 & 0.33 & 5 & 100 & 63 \\
\hline Maximum loss in Disenfranchisement & 2.06 & 2.0 & 0.77 & 1 & 3 & 31 \\
\hline
\end{tabular}




\section{Table 8: The Determinants of Press Coverage}

The dependent variables are different measures of news coverage. In the first two columns it is the log of 1 plus the number of articles in the Financial Times and the Wall Street Journal in the period from $\mathrm{t}-1$ month to $\mathrm{t}+2$ months around the date of the alleged violation. In the third column the dependent variable is one plus the number of articles in the Financial Times during the same period. In the last column it is one plus the number of articles in the Wall Street Journal during the same period. Newsworthiness is the log of the number of references to a company in the WSJ and FT in the 6 month period from January to end of June 1998. Hermitage is the percentage of Hermitage portfolio invested in the company as of end of 1998. All the other control variables are defined in Table 3 . When the violation takes the form of a disenfranchisement, we use a three point scale from lowest (1) to highest (3) severity of the potential loss. All the estimates are obtained by OLS. Huber/ White robust standard errors are reported in brackets, * means significant at 10\%, ** 5\% and *** $1 \%$.

\begin{tabular}{|c|c|c|c|c|}
\hline & \multicolumn{2}{|c|}{$\begin{array}{c}\text { Log of (1+ \# articles in } \\
\text { FT and WSJ) }\end{array}$} & \multirow{2}{*}{\begin{tabular}{|c|}
$\begin{array}{c}\text { Log of }(1+\# \\
\text { articles in FT) }\end{array}$ \\
III \\
\end{tabular}} & \multirow{2}{*}{\begin{tabular}{|c|}
$\begin{array}{c}\text { Log of }(1+\# \\
\text { articles in WSJ) }\end{array}$ \\
IV \\
\end{tabular}} \\
\hline & I & II & & \\
\hline Natural "newsworthiness" & $\begin{array}{c}0.248^{* * *} \\
(0.080) \\
\end{array}$ & $\begin{array}{c}0.128 \\
(0.092) \\
\end{array}$ & $\begin{array}{l}0.163^{*} \\
(0.082)\end{array}$ & $\begin{array}{l}(0.020) \\
(0.052)\end{array}$ \\
\hline $\begin{array}{l}\text { Percentage of Hermitage assets } \\
\text { invested in the company (1998) }\end{array}$ & & $\begin{array}{c}11.340 * * \\
(5.486)\end{array}$ & $\begin{array}{r}6.295 \\
(4.674) \\
\end{array}$ & $\begin{array}{c}11.285^{* * *} \\
(3.445)\end{array}$ \\
\hline Foreign ownership (\%) & $\begin{array}{c}0.555 \\
(0.341)\end{array}$ & $\begin{array}{l}0.572 * \\
(0.301)\end{array}$ & $\begin{array}{c}0.344 \\
(0.252)\end{array}$ & $\begin{array}{l}0.309^{*} \\
(0.185)\end{array}$ \\
\hline EBRD as an investor dummy & $\begin{array}{c}0.030 \\
(0.182)\end{array}$ & $\begin{array}{c}0.126 \\
(0.175)\end{array}$ & $\begin{array}{c}0.147 \\
(0.148)\end{array}$ & $\begin{array}{l}-0.025 \\
(0.113)\end{array}$ \\
\hline Log of assets & $\begin{array}{c}0.087^{* * *} \\
(0.032) \\
\end{array}$ & $\begin{array}{l}0.049 * \\
(0.026)\end{array}$ & $\begin{array}{l}0.044^{*} \\
(0.022)\end{array}$ & $\begin{array}{c}0.014 \\
(0.017)\end{array}$ \\
\hline Dummy for oil industry & $\begin{array}{c}0.189 \\
(0.126)\end{array}$ & $\begin{array}{l}0.222 * \\
(0.123) \\
\end{array}$ & $\begin{array}{l}0.175^{*} \\
(0.098)\end{array}$ & $\begin{array}{c}0.106 \\
(0.081)\end{array}$ \\
\hline \multicolumn{5}{|l|}{ Controls for nature of violation } \\
\hline Share issuance dummy & $\begin{array}{l}-0.059 \\
(0.179)\end{array}$ & $\begin{array}{l}-0.029 \\
(0.170)\end{array}$ & $\begin{array}{c}-0.02 \\
(0.147)\end{array}$ & $\begin{array}{l}-0.006 \\
(0.101)\end{array}$ \\
\hline Share swap dummy & $\begin{array}{c}0.111 \\
(0.339)\end{array}$ & $\begin{array}{c}0.116 \\
(0.344)\end{array}$ & $\begin{array}{c}0.100 \\
(0.292)\end{array}$ & $\begin{array}{c}0.124 \\
(0.192)\end{array}$ \\
\hline Bankruptcy dummy & $\begin{array}{l}-0.028 \\
(0.258)\end{array}$ & $\begin{array}{l}-0.006 \\
(0.252)\end{array}$ & $\begin{array}{c}0.023 \\
(0.215) \\
\end{array}$ & $\begin{array}{c}0.01 \\
(0.137) \\
\end{array}$ \\
\hline Reorganization dummy & $\begin{array}{l}-0.171 \\
(0.244)\end{array}$ & $\begin{array}{l}-0.213 \\
(0.221)\end{array}$ & $\begin{array}{l}-0.147 \\
(0.190)\end{array}$ & $\begin{array}{l}-0.061 \\
(0.123)\end{array}$ \\
\hline Asset stripping dummy & $\begin{array}{l}-0.274 \\
(0.261)\end{array}$ & $\begin{array}{c}-0.628 * * * \\
(0.208) \\
\end{array}$ & $\begin{array}{l}-0.326^{*} \\
(0.180)\end{array}$ & $\begin{array}{c}-0.514 * * * \\
(0.130) \\
\end{array}$ \\
\hline Other form of dilution dummy & $\begin{array}{l}-0.323 \\
(0.340)\end{array}$ & $\begin{array}{c}-0.403 \\
(0.318)\end{array}$ & $\begin{array}{l}-0.262 \\
(0.272)\end{array}$ & $\begin{array}{c}-0.176 \\
(0.188)\end{array}$ \\
\hline Maximum loss due to dilution & $\begin{array}{c}0.001 \\
(0.002) \\
\end{array}$ & $\begin{array}{c}0.001 \\
(0.002) \\
\end{array}$ & $\begin{array}{c}0.001 \\
(0.002) \\
\end{array}$ & $\begin{array}{c}0.000 \\
(0.001)\end{array}$ \\
\hline Maximum loss due to disenfranchisement & $\begin{array}{c}-0.07 \\
(0.069) \\
\end{array}$ & $\begin{array}{l}-0.068 \\
(0.061) \\
\end{array}$ & $\begin{array}{l}-0.049 \\
(0.055) \\
\end{array}$ & $\begin{array}{c}-0.039 \\
(0.031) \\
\end{array}$ \\
\hline Observations & 94 & 94 & 94 & 94 \\
\hline R-squared & 0.468 & 0.526 & 0.522 & 0.482 \\
\hline
\end{tabular}




\section{Table 9: International Press Coverage and Outcomes}

This table summarizes two key features of our sample of 98 observations: whether there was coverage in the international press; and, the type of outcome. The variable 'coverage in the international press' takes on the value 1 if there was any coverage in the Wall Street Journal or Financial Times in the period from t-1 month to $\mathrm{t}+2$ months around the date of the alleged violation and 0 otherwise. In this table we club together outcomes coded as 1 (partial redress) and 2 (full redress) as positive outcome.

\begin{tabular}{|l|c|c|c|c|}
\hline & $\begin{array}{c}\text { Positive } \\
\text { Outome: } \\
\text { Paritally or } \\
\text { Fully } \\
\text { Blocked }\end{array}$ & $\begin{array}{c}\text { Outcome: } \\
\text { Not blocked }\end{array}$ & $\begin{array}{c}\text { Percentage of } \\
\text { Observations } \\
\text { where } \\
\text { Number of } \\
\text { Positive } \\
\text { Outcome }\end{array}$ \\
\hline Media coverage in the International Press & 10 & 7 & 17 & 0.59 \\
\hline No media coverage in the International Press & 18 & 63 & 81 & 0.22 \\
\hline Total & 28 & 70 & 98 & 0.29 \\
\hline Companies where Hermitage fund has a stake & 9 & 11 & 20 & 0.45 \\
\hline \multicolumn{6}{|c|}{ Two-sample Wilcoxon rank-sum (Mann-Whitney) test } \\
\hline \\
Null hypothesis outcome (coverage==0) $=0$ outcome (coverage==1) \\
$\mathrm{z}=-3.021, \quad$ Prob $>|\mathrm{z}|=0.0025$
\end{tabular}




\section{Table 10: The Effect of Press Coverage on Outcomes}

The dependent variable is the outcome of the proposed governance violation. This outcome variable is equal to 0 if the potential governance violation was not redressed at all, 1 if partially redressed, and 2 if substantially redressed. The estimations are obtained using an ordered logit. In column VI of panel A we club outcome 1 and 2 and we run a simple logit. The number of articles is based on a count in the period from t- 1 month to $\mathrm{t}+2$ months around the date of the alleged violation. News coverage in English is a dummy variable that takes the value 1 if there was any news coverage and 0 otherwise. Newsworthiness is measured as the log of one plus the number of references to a company in the WSJ and FT in the 6 month period from January to end of June 1998. All the other control variables are defined in Table 3. Huber/ White robust standard errors are reported in brackets, * means significant at $10 \%$, ** $5 \%$ and $* * * 1 \%$.

Panel 10A:

\begin{tabular}{|c|c|c|c|c|c|c|}
\hline & I & II & III & IV & $\mathbf{V}$ & VI \\
\hline $\begin{array}{l}\text { Total English articles } \\
\text { t- } 1 \text { to } t+2 \text { months }\end{array}$ & & $\begin{array}{c}0.522 * * * \\
(0.153) \\
\end{array}$ & & & & \\
\hline $\begin{array}{l}\text { News coverage in English } \\
\text { Dummy (t-1 to } t+2 \text { months) }\end{array}$ & & & $\begin{array}{c}1.725^{* * *} \\
(0.633)\end{array}$ & & & \\
\hline $\begin{array}{l}\text { Log of (1+\# articles in } \\
\text { FT or WSJ) }\end{array}$ & & & & $\begin{array}{c}1.644^{* * *} \\
(0.425)\end{array}$ & $\begin{array}{c}1.569 * * * \\
(0.505)\end{array}$ & $\begin{array}{c}1.956^{* * *} \\
(0.725)\end{array}$ \\
\hline $\begin{array}{l}\text { Natural } \\
\text { "newsworthiness" }\end{array}$ & & & & & $\begin{array}{c}0.074 \\
(0.250)\end{array}$ & $\begin{array}{c}0.056 \\
(0.337)\end{array}$ \\
\hline Foreign ownership (\%) & $\begin{array}{c}0.021 \\
(1.906)\end{array}$ & $\begin{array}{c}-0.358 \\
(1.971)\end{array}$ & $\begin{array}{l}-1.034 \\
(2.065)\end{array}$ & $\begin{array}{c}-0.886 \\
(1.982)\end{array}$ & $\begin{array}{l}-0.829 \\
(1.974)\end{array}$ & $\begin{array}{c}-0.87 \\
(1.737)\end{array}$ \\
\hline EBRD as an investor dummy & $\begin{array}{c}0.876 \\
(0.658)\end{array}$ & $\begin{array}{l}1.198^{*} \\
(0.669)\end{array}$ & $\begin{array}{c}0.815 \\
(0.668)\end{array}$ & $\begin{array}{c}1.024 \\
(0.668)\end{array}$ & $\begin{array}{c}1.059 \\
(0.691)\end{array}$ & $\begin{array}{l}1.994^{* *} \\
(0.876)\end{array}$ \\
\hline Log of assets & $\begin{array}{c}0.134 \\
(0.158)\end{array}$ & $\begin{array}{c}-0.15 \\
(0.153)\end{array}$ & $\begin{array}{l}-0.042 \\
(0.139)\end{array}$ & $\begin{array}{l}-0.168 \\
(0.151)\end{array}$ & $\begin{array}{c}-0.18 \\
(0.160)\end{array}$ & $\begin{array}{l}-0.191 \\
(0.175)\end{array}$ \\
\hline Dummy for oil industry & $\begin{array}{l}-0.283 \\
(0.739) \\
\end{array}$ & $\begin{array}{l}-0.677 \\
(0.806)\end{array}$ & $\begin{array}{l}-0.675 \\
(0.767)\end{array}$ & $\begin{array}{l}-0.866 \\
(0.812)\end{array}$ & $\begin{array}{l}-0.862 \\
(0.804)\end{array}$ & $\begin{array}{l}-0.708 \\
(0.730)\end{array}$ \\
\hline \multicolumn{7}{|c|}{ Controls for nature of violation } \\
\hline Share issuance dummy & $\begin{array}{c}0.003 \\
(1.292) \\
\end{array}$ & $\begin{array}{l}-0.004 \\
(1.369) \\
\end{array}$ & $\begin{array}{c}0.123 \\
(1.349) \\
\end{array}$ & $\begin{array}{c}0.154 \\
(1.369) \\
\end{array}$ & $\begin{array}{c}0.142 \\
(1.373)\end{array}$ & $\begin{array}{c}-0.11 \\
(1.491)\end{array}$ \\
\hline Share swap dummy & $\begin{array}{l}-1.325 \\
(1.544)\end{array}$ & $\begin{array}{l}-2.185 \\
(1.833)\end{array}$ & $\begin{array}{l}-1.227 \\
(1.529)\end{array}$ & $\begin{array}{l}-1.785 \\
(1.679)\end{array}$ & $\begin{array}{l}-1.753 \\
(1.670)\end{array}$ & $\begin{array}{l}-2.183 \\
(1.914)\end{array}$ \\
\hline Bankruptcy dummy & $\begin{array}{c}-0.731 \\
(1.572)\end{array}$ & $\begin{array}{l}-1.188 \\
(1.756)\end{array}$ & $\begin{array}{l}-0.327 \\
(1.706)\end{array}$ & $\begin{array}{l}-0.775 \\
(1.784)\end{array}$ & $\begin{array}{l}-0.784 \\
(1.785)\end{array}$ & $\begin{array}{l}-0.589 \\
(1.792)\end{array}$ \\
\hline Reorganization dummy & $\begin{array}{c}-0.447 \\
(1.655) \\
\end{array}$ & $\begin{array}{c}-0.689 \\
(1.773) \\
\end{array}$ & $\begin{array}{c}0.054 \\
(1.744) \\
\end{array}$ & $\begin{array}{c}-0.282 \\
(1.773) \\
\end{array}$ & $\begin{array}{l}-0.307 \\
(1.782) \\
\end{array}$ & $\begin{array}{c}0.078 \\
(1.889) \\
\end{array}$ \\
\hline Asset stripping dummy & 2.122 & 2.300 & $2.818^{*}$ & $2.712^{*}$ & $2.684^{*}$ & \\
\hline & $(1.471)$ & $(1.456)$ & $(1.506)$ & $(1.435)$ & $(1.435)$ & \\
\hline Other for of dilution dummy & $\begin{array}{c}0.302 \\
(1.402)\end{array}$ & $\begin{array}{c}0.095 \\
(1.503)\end{array}$ & $\begin{array}{c}0.988 \\
(1.391)\end{array}$ & $\begin{array}{c}0.731 \\
(1.367)\end{array}$ & $\begin{array}{c}0.690 \\
(1.372)\end{array}$ & $\begin{array}{c}0.152 \\
(1.672)\end{array}$ \\
\hline $\begin{array}{l}\text { Maximum loss due to } \\
\text { dilution }\end{array}$ & $\begin{array}{l}0.020^{*} \\
(0.012)\end{array}$ & $\begin{array}{l}0.023^{*} \\
(0.014) \\
\end{array}$ & $\begin{array}{c}0.016 \\
(0.014) \\
\end{array}$ & $\begin{array}{c}0.019 \\
(0.014) \\
\end{array}$ & $\begin{array}{c}0.019 \\
(0.014) \\
\end{array}$ & $\begin{array}{l}0.024^{*} \\
(0.013) \\
\end{array}$ \\
\hline $\begin{array}{l}\text { Maximum loss due to } \\
\text { disenfranchisement }\end{array}$ & $\begin{array}{c}0.281 \\
(0.547) \\
\end{array}$ & $\begin{array}{c}0.431 \\
(0.609) \\
\end{array}$ & $\begin{array}{c}0.379 \\
(0.596) \\
\end{array}$ & $\begin{array}{c}0.493 \\
(0.612) \\
\end{array}$ & $\begin{array}{c}0.486 \\
(0.612)\end{array}$ & $\begin{array}{c}0.349 \\
(0.606) \\
\end{array}$ \\
\hline Observations & 94 & 94 & 94 & 94 & 94 & 93 \\
\hline
\end{tabular}


Panel 10B: Different types of coverage

\begin{tabular}{|c|c|c|}
\hline & I & II \\
\hline Natural "newsworthiness" & $\begin{array}{c}0.452^{* *} \\
(0.219)\end{array}$ & $\begin{array}{c}0.161 \\
(0.270)\end{array}$ \\
\hline Log of (1+ \# articles in Russian newspapers) & $\begin{array}{l}-0.017 \\
(0.359)\end{array}$ & \\
\hline Log of $(1+\#$ articles in FT) & & $\begin{array}{c}0.653 \\
(0.739)\end{array}$ \\
\hline Log of (1+ \# articles in WSJ) & & $\begin{array}{r}1.874^{* *} \\
(0.864) \\
\end{array}$ \\
\hline Foreign ownership (\%) & $\begin{array}{c}0.163 \\
(1.884)\end{array}$ & $\begin{array}{l}-0.795 \\
(2.058) \\
\end{array}$ \\
\hline EBRD as an investor dummy & $\begin{array}{l}1.131^{*} \\
(0.616)\end{array}$ & $\begin{array}{l}1.302^{*} \\
(0.704)\end{array}$ \\
\hline Log of assets & $\begin{array}{c}-0.02 \\
(0.160)\end{array}$ & $\begin{array}{l}-0.172 \\
(0.162)\end{array}$ \\
\hline Dummy for oil industry & $\begin{array}{l}-0.419 \\
(0.764)\end{array}$ & $\begin{array}{l}-0.773 \\
(0.781)\end{array}$ \\
\hline \multicolumn{3}{|l|}{ Controls for nature of violation } \\
\hline Share issuance dummy & $\begin{array}{l}-0.125 \\
(1.318)\end{array}$ & $\begin{array}{c}0.202 \\
(1.397)\end{array}$ \\
\hline Share swap dummy & $\begin{array}{l}-1.356 \\
(1.585)\end{array}$ & $\begin{array}{l}-1.855 \\
(1.678)\end{array}$ \\
\hline Bankruptcy dummy & $\begin{array}{l}-0.835 \\
(1.616)\end{array}$ & $\begin{array}{l}-0.759 \\
(1.764)\end{array}$ \\
\hline Reorganization dummy & $\begin{array}{l}-0.656 \\
(1.725)\end{array}$ & $\begin{array}{l}-0.514 \\
(1.835) \\
\end{array}$ \\
\hline Asset stripping dummy & $\begin{array}{c}2.022 \\
(1.448)\end{array}$ & $\begin{array}{l}2.745^{*} \\
(1.492)\end{array}$ \\
\hline Other form of dilution dummy & $\begin{array}{c}0.058 \\
(1.423)\end{array}$ & $\begin{array}{c}0.502 \\
(1.388)\end{array}$ \\
\hline Maximum loss due to dilution & $\begin{array}{c}0.021 \\
(0.013)\end{array}$ & $\begin{array}{c}0.021 \\
(0.013)\end{array}$ \\
\hline Maximum loss due to disenfranchisement & $\begin{array}{c}0.291 \\
(0.607) \\
\end{array}$ & $\begin{array}{c}0.483 \\
(0.625) \\
\end{array}$ \\
\hline Observations & 94 & 94 \\
\hline
\end{tabular}


Panel 10C: Audience vs. Credibility

\begin{tabular}{|c|c|c|c|}
\hline & I & II & III \\
\hline Natural "newsworthiness" & $\begin{array}{l}0.443^{*} \\
(0.227)\end{array}$ & $\begin{array}{c}0.416 \\
(0.264)\end{array}$ & $\begin{array}{c}0.091 \\
(0.255)\end{array}$ \\
\hline Log of (1+ \# articles in Vedemosti) & $\begin{array}{c}-0.142 \\
(0.510)\end{array}$ & $\begin{array}{c}-0.19 \\
(0.540)\end{array}$ & $\begin{array}{l}-0.239 \\
(0.522)\end{array}$ \\
\hline Log of (1+ \# articles in other Russian newspapers) & & $\begin{array}{c}0.117 \\
(0.360)\end{array}$ & $\begin{array}{l}-0.787 \\
(0.703)\end{array}$ \\
\hline Log of (1+ \# articles in FT or WSJ) & & & $\begin{array}{c}2.318^{* *} \\
(0.928)\end{array}$ \\
\hline Foreign ownership (\%) & $\begin{array}{c}0.056 \\
(1.888) \\
\end{array}$ & $\begin{array}{c}-0.107 \\
(1.913)\end{array}$ & $\begin{array}{l}-0.480 \\
(2.218) \\
\end{array}$ \\
\hline EBRD as an investor dummy & $\begin{array}{l}1.134^{*} \\
(0.612)\end{array}$ & $\begin{array}{l}1.130^{*} \\
(0.618)\end{array}$ & $\begin{array}{l}1.173^{*} \\
(0.656)\end{array}$ \\
\hline Log of assets & $\begin{array}{c}-0.009 \\
(0.160) \\
\end{array}$ & $\begin{array}{c}-0.018 \\
(0.160)\end{array}$ & $\begin{array}{r}-0.153 \\
(0.157) \\
\end{array}$ \\
\hline Dummy for oil industry & $\begin{array}{c}-0.443 \\
(0.769)\end{array}$ & $\begin{array}{c}-0.44 \\
(0.766)\end{array}$ & $\begin{array}{l}-1.243 \\
(0.924)\end{array}$ \\
\hline \multicolumn{4}{|l|}{ Controls for nature of violation } \\
\hline Share issuance dummy & $\begin{array}{r}-0.163 \\
(1.303)\end{array}$ & $\begin{array}{c}-0.154 \\
(1.301)\end{array}$ & $\begin{array}{c}0.167 \\
(1.326)\end{array}$ \\
\hline Share swap dummy & $\begin{array}{l}-1.361 \\
(1.562) \\
\end{array}$ & $\begin{array}{l}-1.383 \\
(1.559) \\
\end{array}$ & $\begin{array}{l}-1.536 \\
(1.661) \\
\end{array}$ \\
\hline Bankruptcy dummy & $\begin{array}{c}-0.876 \\
(1.609)\end{array}$ & $\begin{array}{c}-0.892 \\
(1.615)\end{array}$ & $\begin{array}{c}-0.674 \\
(1.782)\end{array}$ \\
\hline Reorganization dummy & $\begin{array}{l}-0.689 \\
(1.734) \\
\end{array}$ & $\begin{array}{c}-0.701 \\
(1.745)\end{array}$ & $\begin{array}{l}-0.074 \\
(1.781) \\
\end{array}$ \\
\hline Asset stripping dummy & $\begin{array}{c}2.017 \\
(1.452)\end{array}$ & $\begin{array}{c}2.090 \\
(1.426)\end{array}$ & $\begin{array}{l}2.551^{*} \\
(1.545)\end{array}$ \\
\hline Other form of dilution dummy & $\begin{array}{c}0.064 \\
(1.452) \\
\end{array}$ & $\begin{array}{c}0.120 \\
(1.446)\end{array}$ & $\begin{array}{c}0.758 \\
(1.446) \\
\end{array}$ \\
\hline Maximum loss due to dilution & $\begin{array}{l}0.021^{*} \\
(0.013)\end{array}$ & $\begin{array}{c}0.021 \\
(0.013)\end{array}$ & $\begin{array}{c}0.024 \\
(0.016)\end{array}$ \\
\hline Maximum loss due to disenfranchisement & $\begin{array}{c}0.296 \\
(0.584) \\
\end{array}$ & $\begin{array}{c}0.270 \\
(0.601) \\
\end{array}$ & $\begin{array}{c}0.849 \\
(0.681) \\
\end{array}$ \\
\hline Observations & 94 & 94 & 94 \\
\hline
\end{tabular}




\section{Table 11: The Instrumental Variable Estimates}

In this table we again look at outcome as the dependent variable. Outcome is defined to be equal to 0 if the potential governance violation was not redressed at all, 1 if partially redressed and 2 if substantially redressed. Column I is estimated by OLS. Column II is estimated by Instrumental Variables (IV), where the instrument for the log of the number of articles in the FT and WSJ is the percentage of Hermitage portfolio invested in a company at the end of 1998. Newsworthiness is measured as the log of one plus the number of references to a company in the WSJ and FT in the 6 month period from January to end of June 1998. We define control variables in Table 3. All the estimates are obtained by OLS. Huber/ White robust standard errors are reported in brackets, * means significant at $10 \%, * * 5 \%$ and $* * * 1 \%$.

\begin{tabular}{|l|c|c|}
\hline & OLS & IV \\
\hline Log of (1+ \# articles in FT or WSJ) & $0.438^{* * *}$ & $0.855^{* *}$ \\
& $(0.148)$ & $(0.432)$ \\
\hline Natural "newsworthiness" & 0.051 & -0.053 \\
& $(0.071)$ & $(0.133)$ \\
\hline Foreign ownership (\%) & -0.111 & -0.342 \\
& $(0.567)$ & $(0.609)$ \\
\hline EBRD as an investor dummy & 0.288 & 0.275 \\
& $(0.221)$ & $(0.248)$ \\
\hline Log of assets & -0.048 & -0.084 \\
& $(0.043)$ & $(0.059)$ \\
\hline Dummy for oil industry & -0.155 & -0.234 \\
& $(0.187)$ & $(0.190)$ \\
\hline Controls for nature of violation & \multicolumn{2}{|c|}{} \\
\hline Share issuance dummy & 0.014 & 0.039 \\
& $(0.324)$ & $(0.331)$ \\
\hline Share swap dummy & -0.416 & -0.462 \\
& $(0.336)$ & $(0.416)$ \\
\hline Bankruptcy dummy & -0.303 & -0.291 \\
& $(0.392)$ & $(0.414)$ \\
\hline Reorganization dummy & -0.192 & -0.121 \\
& $(0.435)$ & $(0.441)$ \\
\hline Asset stripping dummy & $0.760 *$ & $0.875 * *$ \\
& $(0.387)$ & $(0.395)$ \\
\hline Other form of dilution dummy & 0.104 & 0.239 \\
& $(0.318)$ & $(0.333)$ \\
\hline Maximum loss due to dilution & 0.005 & 0.005 \\
& $(0.003)$ & $(0.004)$ \\
\hline Maximum loss due to disenfranchisement & 0.097 & 0.126 \\
& $(0.136)$ & $(0.135)$ \\
\hline Observations & 94 & 94 \\
\hline R-squared & 0.22 & 0.148 \\
\hline
\end{tabular}




\section{Table 12: Who Acts to Redress Reported Corporate Governance Violations?}

In this table we classify the successful outcomes according to the primary mechanism through which media pressure worked. Coding of the primary mechanism is based upon a reading of the Russian and English language press.

\begin{tabular}{|c|c|c|c|c|}
\hline & \multicolumn{2}{|c|}{ Intervention by Government Actors } & \multicolumn{2}{|c|}{ Private Sector Actors } \\
\hline & $\begin{array}{l}\text { Intervention of } \\
\text { regulators/courts }\end{array}$ & $\begin{array}{c}\text { Political } \\
\text { intervention }\end{array}$ & $\begin{array}{l}\text { Company relents } \\
\text { when faced with } \\
\text { significant } \\
\text { opposition }\end{array}$ & Company relents \\
\hline & \begin{tabular}{|l} 
AvtoVAZ \\
Irkutskelectrosvyaz \\
Kuznetsk Ferrous \\
Alloys \\
Tomsk Refinery \\
Tomskneft \\
Yuganskneftegaz \\
Sidanco \\
Lomonosov \\
Porcelain \\
Elektrosila \\
AVISMA
\end{tabular} & $\begin{array}{l}\text { Gazprom } \\
\text { RAO UES } \\
\text { Sberbank } \\
\text { Novoship }\end{array}$ & $\begin{array}{l}\text { KAMAZ } \\
\text { KrAZ } \\
\text { Ust-Ilimsk Timber } \\
\text { Viksunsk Pipe } \\
\text { Bratsk Pulp } \\
\text { KomiTEK } \\
\text { Volgotanker } \\
\text { VSMPO }\end{array}$ & $\begin{array}{l}\text { Chernogorneft } \\
\text { GAZ } \\
\text { Gazprom } \\
\text { Transneft } \\
\text { Rosshelf } \\
\text { Bashkirenergo }\end{array}$ \\
\hline $\begin{array}{l}\text { Number of } \\
\text { cases }\end{array}$ & 10 & 4 & 8 & 6 \\
\hline $\begin{array}{l}\text { Percentage of } \\
\text { cases with } \\
\text { positive } \\
\text { outcome } \\
\end{array}$ & $36 \%$ & $14 \%$ & $29 \%$ & $21 \%$ \\
\hline
\end{tabular}

